\title{
Nepal Ambient Monitoring and Source Testing Experiment (NAMaSTE): emissions of trace gases and light-absorbing carbon from wood and dung cooking fires, garbage and crop residue burning, brick kilns, and other sources
}

\author{
Chelsea E. Stockwell ${ }^{1, \text { a }}$, Ted J. Christian ${ }^{1}$, J. Douglas Goetz ${ }^{2}$, Thilina Jayarathne ${ }^{3}$, Prakash V. Bhave ${ }^{4}$, \\ Puppala S. Praveen ${ }^{4}$, Sagar Adhikari ${ }^{5}$, Rashmi Maharjan ${ }^{5}$, Peter F. DeCarlo ${ }^{2}$, Elizabeth A. Stone ${ }^{3}$, Eri Saikawa ${ }^{6}$, \\ Donald R. Blake $^{7}$, Isobel J. Simpson ${ }^{7}$, Robert J. Yokelson ${ }^{1}$, and Arnico K. Panday ${ }^{4}$ \\ ${ }^{1}$ Department of Chemistry, University of Montana, Missoula, MT 59812, USA \\ ${ }^{2}$ Departments of Chemistry and Civil, Architectural, and Environmental Engineering, \\ Drexel University, Philadelphia, PA 19104, USA \\ ${ }^{3}$ Department of Chemistry, University of Iowa, Iowa City, IA 52242, USA \\ ${ }^{4}$ International Centre for Integrated Mountain Development (ICIMOD), Khumaltar, 44700, Nepal \\ ${ }^{5}$ MinErgy Pvt. Ltd, Lalitpur, 9354, Nepal \\ ${ }^{6}$ Department of Environmental Sciences, Emory University, Atlanta, GA 30322, USA \\ ${ }^{7}$ Department of Chemistry, University of California-Irvine, Irvine, CA 92697, USA \\ ${ }^{a}$ now at: Chemical Sciences Division, NOAA Earth System Research Laboratory, Boulder, CO 80305, USA
}

Correspondence to: Robert J. Yokelson (bob.yokelson@umontana.edu)

Received: 18 February 2016 - Published in Atmos. Chem. Phys. Discuss.: 21 March 2016

Revised: 22 August 2016 - Accepted: 23 August 2016 - Published: 7 September 2016

\begin{abstract}
The Nepal Ambient Monitoring and Source Testing Experiment (NAMaSTE) campaign took place in and around the Kathmandu Valley and in the Indo-Gangetic Plain (IGP) of southern Nepal during April 2015. The source characterization phase targeted numerous important but undersampled (and often inefficient) combustion sources that are widespread in the developing world such as cooking with a variety of stoves and solid fuels, brick kilns, open burning of municipal solid waste (a.k.a. trash or garbage burning), crop residue burning, generators, irrigation pumps, and motorcycles. NAMaSTE produced the first, or rare, measurements of aerosol optical properties, aerosol mass, and detailed trace gas chemistry for the emissions from many of the sources. This paper reports the trace gas and aerosol measurements obtained by Fourier transform infrared (FTIR) spectroscopy, whole-air sampling (WAS), and photoacoustic extinctiometers (PAX; 405 and $870 \mathrm{~nm}$ ) based on field work with a moveable lab sampling authentic sources. The primary aerosol optical properties reported include emission factors (EFs) for scattering and absorption coefficients (EF $B_{\text {scat }}$,
\end{abstract}

EF $B_{\text {abs }}$, in $\mathrm{m}^{2} \mathrm{~kg}^{-1}$ fuel burned), single scattering albedos (SSAs), and absorption Ångström exponents (AAEs). From these data we estimate black and brown carbon $(\mathrm{BC}, \mathrm{BrC})$ emission factors $\left(\mathrm{g} \mathrm{kg}^{-1}\right.$ fuel burned). The trace gas measurements provide $\mathrm{EFs}\left(\mathrm{g} \mathrm{kg}^{-1}\right)$ for $\mathrm{CO}_{2}, \mathrm{CO}, \mathrm{CH}_{4}$, selected non-methane hydrocarbons up to $\mathrm{C}_{10}$, a large suite of oxygenated organic compounds, $\mathrm{NH}_{3}, \mathrm{HCN}, \mathrm{NO}_{x}, \mathrm{SO}_{2}, \mathrm{HCl}$, $\mathrm{HF}$, etc. (up to $\sim 80$ gases in all).

The emissions varied significantly by source, and light absorption by both $\mathrm{BrC}$ and $\mathrm{BC}$ was important for many sources. The AAE for dung-fuel cooking fires $(4.63 \pm 0.68)$ was significantly higher than for wood-fuel cooking fires $(3.01 \pm 0.10)$. Dung-fuel cooking fires also emitted high levels of $\mathrm{NH}_{3}\left(3.00 \pm 1.33 \mathrm{~g} \mathrm{~kg}^{-1}\right)$, organic acids $\left(7.66 \pm 6.90 \mathrm{~g} \mathrm{~kg}^{-1}\right)$, and $\mathrm{HCN}\left(2.01 \pm 1.25 \mathrm{~g} \mathrm{~kg}^{-1}\right)$, where the latter could contribute to satellite observations of high levels of $\mathrm{HCN}$ in the lower stratosphere above the Asian monsoon. HCN was also emitted in significant quantities by several non-biomass burning sources. BTEX compounds (benzene, toluene, ethylbenzene, xylenes) were ma- 
jor emissions from both dung- $\left(\sim 4.5 \mathrm{~g} \mathrm{~kg}^{-1}\right)$ and wood-fuel $\left(\sim 1.5 \mathrm{~g} \mathrm{~kg}^{-1}\right)$ cooking fires, and a simple method to estimate indoor exposure to the many measured important air toxics is described. Biogas emerged as the cleanest cooking technology of approximately a dozen stove-fuel combinations measured. Crop residue burning produced relatively high emissions of oxygenated organic compounds $\left(\sim 12 \mathrm{~g} \mathrm{~kg}^{-1}\right)$ and $\mathrm{SO}_{2}\left(2.54 \pm 1.09 \mathrm{~g} \mathrm{~kg}^{-1}\right)$. Two brick kilns co-firing different amounts of biomass with coal as the primary fuel produced contrasting results. A zigzag kiln burning mostly coal at high efficiency produced larger amounts of BC, HF, $\mathrm{HCl}$, and $\mathrm{NO}_{x}$, with the halogenated emissions likely coming from the clay. The clamp kiln (with relatively more biomass fuel) produced much greater quantities of most individual organic gases, about twice as much $\mathrm{BrC}$, and significantly more known and likely organic aerosol precursors. Both kilns were significant $\mathrm{SO}_{2}$ sources with their emission factors averaging $12.8 \pm 0.2 \mathrm{~g} \mathrm{~kg}^{-1}$. Mixed-garbage burning produced significantly more BC $\left(3.3 \pm 3.88 \mathrm{~g} \mathrm{~kg}^{-1}\right)$ and BTEX $\left(\sim 4.5 \mathrm{~g} \mathrm{~kg}^{-1}\right)$ emissions than in previous measurements. For all fossil fuel sources, diesel burned more efficiently than gasoline but produced larger $\mathrm{NO}_{x}$ and aerosol emission factors. Among the least efficient sources sampled were gasoline-fueled motorcycles during start-up and idling for which the CO EF was on the order of $\sim 700 \mathrm{~g} \mathrm{~kg}^{-1}-$ or about 10 times that of a typical biomass fire. Minor motorcycle servicing led to minimal if any reduction in gaseous pollutants but reduced particulate emissions, as detailed in a companion paper (Jayarathne et al., 2016). A small gasolinepowered generator and an "insect repellent fire" were also among the sources with the highest emission factors for pollutants. These measurements begin to address the critical data gap for these important, undersampled sources, but due to their diversity and abundance, more work is needed.

\section{Introduction}

Several major atmospheric sources such as temperate forest biogenic emissions (e.g., Ortega et al., 2014), developedworld pollution from fossil fuel use (e.g., Ryerson et al., 2013), and laboratory-simulated biomass burning (BB) (e.g., Stockwell et al., 2014) have been sampled extensively with a wide range of instrumentation; but many important emission sources remain unsampled, or rarely sampled, by reasonably comprehensive efforts (Akagi et al., 2011). As the emissions of greenhouse gases and other air pollutants from developing countries have grown in importance for air quality and regional-global climate studies, the need for a more detailed understanding of these emissions has increased. For example, the diverse and loosely regulated combustion sources of South Asia are poorly characterized and greatly undersampled relative to their proportion of global emissions (Akagi et al., 2011). These sources include industrial and domestic bio- fuel use (e.g., cooking fires), brick kilns, poorly maintained vehicles, open burning of garbage and crop residue, diesel and gasoline generators, and irrigation pumps.

Approximately 2.8 billion people worldwide burn solid fuels (e.g., wood, dung, charcoal, coal) for domestic (household) cooking and heating (Smith et al., 2013) with the largest share in Asia. Cooking fires are the largest source of soot in South Asia (Ramanathan and Carmichael, 2008). Industrial solid fuel use (e.g., brick kilns) is ubiquitous but difficult to quantify in the developing world as it is not highly regulated or adequately inventoried and can involve a variety of fuels (e.g., coal, sawdust, wood, garbage, tires, crop residue) (Christian et al., 2010). Along with industrial and domestic solid fuel use, open burning of agricultural waste and garbage, gasoline and diesel-powered generators, and many examples of high-emitting vehicles are prevalent but grossly undersampled in the developing world with previous field emissions characterization usually limited to a few trace gases and a few particulate species such as black carbon (BC) mass (Bertschi et al., 2003; Christian et al., 2010; Akagi et al., 2011; Bond et al., 2013).

Understanding the local to global impacts of these sources is vital to modeling atmospheric chemistry, climate, and, notably, air quality as these sources most commonly occur indoors or near or within population centers. Aerosols directly affect climate through both absorption and the scattering of solar radiation and indirectly affect climate by modifying clouds (Bond and Bergstrom, 2006). Therefore, global modeling of radiative forcing requires (among other things) accurate information on the amount and optical properties of aerosol emissions (Reid et al., 2005). BB is a major source of $\mathrm{BC}$ in the atmosphere, but it also dominates the global emissions of weakly absorbing organic aerosol known as brown carbon $(\mathrm{BrC})$. $\mathrm{BrC}$ has a contribution to the total absorption of $\mathrm{BB}$ aerosol that is poorly constrained but critical to determining whether the net forcing of $\mathrm{BB}$ aerosol is positive or negative (Feng et al., 2013; Chen and Bond, 2010). Open burning of biomass and household-level consumption of biofuel account for a majority of BC emissions in important regions including Asia, but data are limited about how much $\mathrm{BrC}$ is emitted from biofuel and biomass combustion (Kirchstetter et al., 2004; Chen and Bond, 2010; Hecobian et al., 2010; Arola et al., 2011). In general, there is significant uncertainty in emissions inventories since $\mathrm{BrC}$ is rarely tabulated as a separate species though the scattering and absorption of both $\mathrm{BC}$ and $\mathrm{BrC}$ are necessary to model radiative transfer (Clarke et al., 1987).

Additionally, the secondary formation of organic aerosol and ozone as well as the evolution of the $\mathrm{BC}$ and $\mathrm{BrC}$ optical properties are strongly influenced by the co-emitted gases and particles via processes such as coagulation, evaporation, oxidation, and condensation (Alvarado et al., 2015; May et al., 2015). Near-source measurements of light absorption and scattering by $\mathrm{BC}$ and $\mathrm{BrC}$ and their emission factors (EFs), along with the suite of co-emitted gas-phase precursors, are 
needed to better estimate the impacts of these undersampled sources on climate, chemistry, and local-global air quality, especially in regions that lack comprehensive sampling.

Current reviews of global $\mathrm{BC}$ emissions note that global models likely underestimate BC absorption in several important regions including South Asia (Bond et al., 2013), making this an important area where undersampled emission sources have critical climate and chemistry impacts. BC emissions from South Asia may negatively impact important regional water resources (Menon et al., 2010) and contribute significantly to the warming of the Arctic (Allen et al., 2012; Sand et al., 2013), and emissions of volatile organic compounds (VOCs) and nitrogen oxides $\left(\mathrm{NO}_{x}\right)$ in this region were estimated to influence global warming more significantly than similar emissions from other Northern Hemisphere regions (Collins et al., 2013). Thus, these sources contribute significantly to the local-global burden of primary aerosol, greenhouse gases, and reactive trace gases. Crudely estimating their activity and the composition of their emissions can lead to significant errors and uncertainties in regional and global atmospheric models (Dickerson et al., 2002; Venkataraman et al., 2005; Adhikary et al., 2007, 2010; Akagi et al., 2011; Bond et al., 2013; Wiedinmyer et al., 2014).

The Nepal Air Monitoring and Source Testing Experiment (NAMaSTE) was a collaborative effort with multiple goals: (1) providing detailed chemistry, physical properties, and EFs for the trace gases and aerosols produced by many undersampled BB sources, a poorly maintained transport sector, brick kilns, etc.; (2) using these new emissions data to expand and update emissions inventories including the Nepal national inventory; (3) supporting a source apportionment for Kathmandu, Nepal; (4) enhancing regional air quality and climate modeling; and (5) informing mitigation strategies. The project involved the International Centre for Integrated Mountain Development (ICIMOD, the in-country lead), MinErgy (a local contractor to ICIMOD), the Institute for Advanced Sustainability Studies (IASS, fixed-site support), and the universities of Drexel, Emory, Iowa (UI), California, Irvine (UCI), Montana (UM), and Virginia (UVA) in the US.

NAMaSTE employed two strategies simultaneously in the first measurement phase. A temporary supersite was set up at a representative suburban Kathmandu location (Bode) to augment the ongoing monitoring that was initiated there in 2012 (Chen et al., 2015; Lüthi et al., 2015; Putero et al., 2015; Sarkar et al., 2016) and to provide a target receptor for the source apportionment. Simultaneously, a well-equipped mobile team investigated numerous undersampled emissions sources in and around the Kathmandu Valley and in the rural Tarai region in the Indo-Gangetic Plain (IGP) of southern Nepal. The sources represented authentic, common practices but were usually not random and were arranged by the MinErgy and ICIMOD team before the campaign. The source and fixed-site measurements commenced on 11 April of 2015 but were cut short by the Gorkha earthquake on 25 April.
The early termination prevented the sampling of on-road mobile sources including heavy-duty diesel trucks, which is now planned for phase two. Additional measurements of cooking fires and other sources planned in the Makwanpur District in the foothills south of Kathmandu were also canceled, but many valuable data on similar sources had already been gathered. In this paper we present a brief summary of the source sampling campaign and the details of the trace gas measurements of fresh emissions obtained by Fourier transform infrared (FTIR) spectroscopy and whole-air sampling (WAS). We also present photoacoustic extinctiometer (PAX) data cocollected at 405 and $870 \mathrm{~nm}$ to measure the optical properties and estimate the mass of the fresh $\mathrm{BC}$ and $\mathrm{BrC}$ emissions. Substantial additional source characterization data based on sampling with Teflon and quartz filters and a suite of other real-time aerosol instruments will be presented separately (Jayarathne et al., 2016; Goetz et al., 2016). Several weeks of high-quality filter, WAS, aerosol mass spectrometer, and other real-time data from the supersite at Bode will also be presented and discussed separately. Taken together, the NAMaSTE efforts begin to reduce the information gap for these important undersampled sources.

\section{Experimental details}

\subsection{Source types and site descriptions}

Nepal has variable terrain ranging from high mountains to the low-elevation plains in the Tarai. Our team was based out of the major population center of Kathmandu and we traveled by truck to various locations in and around the Kathmandu Valley while also traveling south to the Tarai region. The Tarai sits on the southern edge of Nepal in the IGP with intensive agriculture, terrain, and other similarities to the heavily populated region of northern India. The emissions data we present were obtained from many sources including two-wheeled vehicles (motorcycles and scooters), diesel- and gasoline-powered generators, agricultural pumps, garbage fires, cooking fires, crop residue burning, and brick kilns. This section briefly summarizes the significance of each source and how they were sampled in our study.

\subsubsection{Motorcycles and scooters}

Mobile emissions are extremely important in urban areas as they contribute significantly to the degradation of air quality on local to regional scales (Molina and Molina, 2002, 2004; Molina et al., 2007; Dunmore et al., 2015). In the Kathmandu Valley, approximately $80 \%$ of registered vehicles are motorcycles or scooters and this is the fastest growing portion of the transport sector in Kathmandu and nationally (MOPIT, 2014). Motorcycles are generally larger with larger engines than scooters and in Nepal both now burn unleaded Euro3 gasoline. Together, nationally, these two-wheeled vehicles consume about one third of the gasoline and $\sim 10 \%$ of to- 
tal fuel used for on-road transport (WECS, 2014), with total sales of diesel and gasoline approaching $1 \mathrm{Tg}$ in 2015 (Nepal Oil Corporation Limited, 2015). Vehicle EFs are commonly obtained from bulk exhaust measurements (USEPA, 2015) and the International Vehicle Emissions (IVEs) model specifically generates EF for mobile sources in the developing world (Shrestha et al., 2013). However, the detailed source chemistry (e.g., specific air toxics) is poorly known, especially for the developing world, as most studies focus only on $\mathrm{CO}, \mathrm{NO}_{x}, \mathrm{PM}_{2.5}$, and a few hydrocarbons or total VOC in developed countries (e.g., Zhang et al., 1993; Pang et al., 2014).

There are a number of approaches to measure vehicular emissions that include in-use sampling while driving as well as more controlled dynamometer studies (Yanowitz et al., 1999; Pelkmans and Debal, 2006). Franco et al. (2013) outline the advantages and drawbacks to these various sampling techniques, though we will not discuss them further here. We were able to measure the emissions exhaust of five motorcycles and one scooter during start-up and idling, which are considered common traffic situations in the Kathmandu Valley. On 13 April 2015, we set up the NAMaSTE emissions measuring equipment next to a motorcycle repair shop, and to limit sampling bias, we deliberately tested every motorcycle or scooter that entered the shop for servicing that day. Each motorcycle and scooter was sampled (start-up and idling) pre- and post-servicing (one motorcycle was not sampled post-service). The motorcycle or scooter brand, model, etc., are shown in Table S1. The maintenance routine included an oil change, cleaning the air filters and spark plugs, and adjusting the carburetor.

\subsubsection{Generators}

Nepal has no significant fossil fuel resources and insufficient hydropower. As a result, load shedding for many hours per day is common nationally and diesel- or gasolinepowered generators (a.k.a. gensets) are critical infrastructure for industrial, commercial, institutional, and household use, consuming about $57000 \mathrm{Mg}$ of fuel per year (World Bank, 2014). Based on fuel use, the emissions from generators could be about $6 \%$ of those from the transport sector. A large variety of generators are deployed to meet various size, power, and load capacity needs. In this study we sampled exhaust emissions from one small diesel generator with $5 \mathrm{kVA}$ capacity (Chanqta, CED6500s) and a much larger diesel generator, located on the ICIMOD campus, with $100 \mathrm{kVA}$ capacity running at $1518 \mathrm{rpm}$ ( $85 \%$ of full load). In addition to the two diesel generators, we sampled the exhaust emissions from one gasoline-fueled generator (Yeeda, Y-113(1133106)) that had a similar capacity (4kVA) to the smaller diesel generator. Most pollutants from these engines are emitted through the exhaust, though some fraction likely escapes from fuel evaporation.

\subsubsection{Agricultural water pumps}

The use of diesel-powered agricultural pumps to extract groundwater for irrigation is rapidly rising in rural regions of Nepal and India with few to no operational regulations (Barker and Molle, 2004). The dependence on dieseloperated pumps is likely to rise in South Asia as crop production rises with population demands. Although massive groundwater extraction has aided agricultural productivity in the region, the environmental impacts are seldom investigated (Shah et al., 2000). The pumps are estimated to consume $\sim 1.3 \mathrm{Tg} \mathrm{yr}^{-1}$ of diesel fuel, over the entire IGP. Dieselpowered engine emissions can cause adverse health effects and unfavorable impacts on air quality, climate, crops, and soils (Lloyd and Cackette, 2001). We sampled the exhaust from two smaller diesel pumps (Kirloskar, 4.6kVA, and Field Marshall R170a, $5 \mathrm{kVA}$ ) in the Tarai. We also sampled the exhaust opportunistically from a much larger irrigation pump (Shineray) in suburban Kathmandu. We were unable to confirm fuel type but suspect it was gasoline based on the emissions chemistry.

\subsubsection{Garbage burning}

Open burning of garbage is poorly characterized even in the most "developed" countries where it occurs with minimal oversight mostly in rural areas (USEPA, 2006). In developing countries open burning of garbage is much more prevalent, poorly characterized, and much less regulated if at all. In Nepal, as throughout the developing world, open burning of garbage is ubiquitous on a range of scales. Small, meterscale piles of burning trash are seen along roads and in uncultivated fields. Approximately 10-20 times larger areas of burning trash are also common at landfills, along roadsides and riverbanks, and basically many accessible, uncultivated open spaces, with these areas evidently serving as an informal public resource. Given the large amount of refuse generated and the lack of economically viable alternatives to burning (Pokhrel and Viraraghavan, 2005), garbage burning is estimated to consume about $644000 \mathrm{Mg}$ of municipal solid waste (MSW) annually in Nepal (Wiedinmyer et al., 2014) and have a major impact on air quality, health, and atmospheric chemistry. The few available previous measurements of garbage burning suggest it is particularly important as a source of BC, hydrogen chloride, particulate chloride, several ozone precursors, and air toxics such as dioxins (Costner, 2005; Christian et al., 2010; Li et al., 2012; Lei et al., 2013; Wiedinmyer et al., 2014; Stockwell et al., 2014, 2015). To our knowledge only one study reports reasonably comprehensive EFs for authentic open burning of garbage in the developing world, namely the landfill fire sampling in Mexico of Christian et al. (2010). Several lab studies have measured the emissions from garbage burning under controlled conditions in great chemical detail (Yokelson et al., 2013; Stockwell et al., 2014, 2015), but the relevance of these lab 
experiments needs further evaluation against a better picture of real-world garbage burning. More real-world data are also needed to evaluate and update the garbage burning global inventory mentioned above (Wiedinmyer et al., 2014).

During NAMaSTE, we were able to contribute a modest but important expansion of the real-world garbage burning sampling. We sampled mixed-garbage burning on six occasions, and we conducted three experiments burning segregated trash since some processing of garbage before combustion is common. The segregated trash experiments isolated plastics and foil-lined bags in separate individual burns. The components in each garbage burn are summarized in Table S2 in the Supplement. The overall carbon fraction for mixed waste was calculated in Stockwell et al. (2014) by estimating the carbon content of each component in the mixture, and the value of overall carbon content calculated therein is assumed in our mixed-garbage EF calculations (0.50). Polyethylene terephthalate (PET) is the most common plastic used in metallized packaging, as is the case for chip and other foil-lined bags, and has a carbon fraction of 0.63 (USEPA, 2010). Most plastic bags are composed of high- and low-density polyethylene (HDPE, LDPE) mixed with PET, and thus we estimate a carbon content of 0.745 in this study (USEPA, 2010).

\subsubsection{Cooking stoves}

Most global estimates of domestic biofuel consumption ( $\sim 3000 \mathrm{Tg} \mathrm{yr}^{-1}$ ) designate domestic biofuel burning as the second-largest BB source behind savanna fires (Akagi et al., 2011). In the developing world, it is estimated that the majority of biomass fuel is burned in Asia ( $~ 66 \%$; Yevich and Logan, 2003). The solid fuels regularly burned include wood-derived fuels (e.g., hardwood, twigs, sawdust, charcoal) and agricultural residues (e.g., crop waste, livestock dung) though the fuel choice depends on availability, local customs, and the season. Yevich and Logan (2003) estimate residential wood-fuel use for Nepal in 1985 as $9.8 \mathrm{Tg} \mathrm{yr}^{-1}$. They do not estimate dung-fuel use in Nepal, but the data they provide for Indian states with populations similar to Nepal suggests that about $1-2 \mathrm{Tg} \mathrm{yr}^{-1}$ of dung is combusted residentially in Nepal.

The cooking-fire measurements in this study were conducted in two phases. First, measurements were conducted by simulating field cooking in a laboratory to capture emissions from a wide range of stove and fuel types. Fuels for the lab tests included wood, dung, mixed wood and dung, biobriquettes, and biogas. Stove types included traditional singlepot mud stove, open three-stone, bhuse chulo (insulated vertical combustion chamber), rocket stove, chimney stove, and forced draft stove. In the second phase, cooking emissions were sampled from authentic cooking fires in the kitchens of several rural Nepali homes and one restaurant operated out of a personal kitchen. The two kitchens that utilized the traditional one-pot clay stove were separated from the main dwelling by a mud wall. The ventilation for all cases was by passive draft through the door, open windows, and gaps between the walls and roof. Smoke samples were taken from the upper corner of the kitchen where the inflow and outflow of emissions were somewhat balanced and we were able to grab representative samples of accumulated emissions not needing weighting by the fire-driven flow. Several biofuels are available to the home and restaurant owners including twigs and larger pieces of hardwood (Shorea robusta and Melia azedarach (Bakaino)) and dung shaped into logs or cakes sometimes containing minor amounts of straw. Different fuels or a combination of fuels were consumed depending on cooking preference. Our study was designed to bring more comprehensive trace gas and aerosol field sampling to the effort to understand cooking fires. We note that the women tending to the cookstoves went in and out of the kitchens with their children during food preparation, so exposure is also a concern. While our concentration data could be used directly for indoor exposure estimates, a better approach for estimating exposure to the air toxics we report is via our ratios to commonly measured species in the available studies more focused on representative exposure.

\subsubsection{Crop residue}

Crop residue burning is ubiquitous during the dry season in the Kathmandu Valley and rural Nepal. Globally, burning crop residue post-harvest is widely practiced to enable faster crop rotation; reduce weeds, disease, and pests; and return nutrients to the soil. Alternatives to crop residue burning such as plowing residue into the soil or use as livestock feed have drawbacks including increased risk of wind erosion of topsoil and poor "feed" nutritional quality (Owen and Jayasuriya, 1989). Thus, open burning of crop residue is a prevalent activity in both developing and developed countries and it has important atmospheric impacts, but the emissions are not well characterized (Yevich and Logan, 2003; Streets et al., 2013; Sinha et al., 2014). Data for Indian states with a similar population to Nepal suggest that total annual crop residue burning in Nepal is on the order of 6-7 $\mathrm{Tg} \mathrm{yr}^{-1}$ (Yevich and Logan, 2003).

The land use in southern Nepal is representative of the much larger Indo-Gangetic Plain, which are inhabited by nearly a billion people. Crop residue types may impact emissions significantly; thus, mostly in the Tarai, we characterized emissions from two regionally important crop types separately: rice straw and wheat. Additionally, we sampled the emissions from the burning of other crop residue types important in this region including mustard residue, grass, and a mixture of these residues. The carbon fractions assumed in this study were taken from previous analyses of similar fuels compiled in Table 1 of Stockwell et al. (2014). 


\subsubsection{Brick kilns}

Brick production is an important industry in South Asia and the number of brick kilns in Nepal and India combined likely exceeds 100000 (Maithel et al., 2012) with perhaps $\sim 1000$ kilns in Nepal that would likely require $\sim 1-2 \mathrm{Tg}$ of fuel per year. However, the industry is neither unambiguously inventoried nor strongly regulated. The previous trace gas and particulate emissions data available on brick kilns are very limited (Christian et al., 2010; Weyant et al., 2014). We were not able to sample a large number of kilns in Nepal, but we were able to greatly expand the number of important trace gas and aerosol species and properties quantified.

During NAMaSTE, we sampled two brick kilns just outside the Kathmandu Valley that employed different common and regionally important technologies. The first kiln sampled was a zigzag kiln, which is considered relatively advanced due to an airflow system that efficiently transfers heat to multiple brick chambers. We note that most zigzag kilns in the Kathmandu Valley have a chimney upwards of $18 \mathrm{~m}$ high to minimize impacts on immediate neighbors. The tall stacks have been sampled from a port on the side, which is useful but raises uncertainties due to possible condensation after sampling hot and moist exhaust or losses on stack walls past the sampling point. Therefore, we elected to sample the zigzag emissions from a kiln outside the valley with a shorter chimney and where our inlet could be within several meters of the chimney where emissions had cooled to nearambient temperature. This approach was followed to reliably sample the "real" emissions. The zigzag chimney emissions were sampled for $5 \mathrm{~h}$ (09:00-14:00), which captured several firing-feeding cycles lasting about $1 \mathrm{~h}$ each. By cycles we refer to the periodic addition of a primarily coal-bagasse mix during the day through multiple feeding orifices (a.k.a. stoke holes) above the firing chamber that were moved as the firing progressed. We also occasionally diverted the sampling to capture the emissions from these stoke holes. The smoke emitted from both the chimney and stoke holes mostly appeared white with occasional puffs of brown smoke when coal was added through the stoke holes.

The second kiln was a common batch-type clamp kiln. In clamp kilns, green unfired bricks are stacked and brick walls are built up to surround the unfired bricks. Each batch is stacked, fired, cooled and must be unloaded before firing the next batch. There is no chimney to vent emissions as the kiln ventilates freely through the sides and roof. The naturally escaping emissions were sampled at or near-ambient temperature about $1 \mathrm{~m}$ from the roof throughout the day. The clamp kiln smoke always appeared white with no apparent periods of black smoke.

Generally the cheapest type of coal available is used in South Asian kilns. Bricks are typically fired to $700-1100^{\circ} \mathrm{C}$, consuming significant amounts of coal and biomass as detailed elsewhere (Maithel et al., 2012). The practice of biomass co-firing to reduce the use of coal is common as it reduces expense, but co-firing in general is also known to reduce fossil- $\mathrm{CO}_{2}$ emissions and some criteria pollutants such as $\mathrm{NO}_{x}$ and $\mathrm{SO}_{2}$ (e.g., Al-Naiema et al., 2015). We expect that the emissions change depending on the biomass-to-coal blending ratios in South Asia and that the blend likely varies considerably between kilns. In the two kilns we measured the primary fuel was coal; however, the clamp kiln was more substantially co-fired with biomass. The coal piles next to the clamp kiln were adjacent to large piles of cut hardwood; thus, the coal was likely co-fired with a substantial amount of hardwood and the emissions data confirms that. We note that we were not on site long enough to measure the emissions from the entire kiln lifetime. Thus, we cannot probe seasonal variation in brick kiln emissions. However, we did capture four to five entire firing cycles from each kiln that should represent the emissions near the end of the dry season production period. Some kiln operators suspect that these emissions may reflect more efficient combustion (and more bricks per kilogram fuel) than when the kilns are first started up in January under conditions of lower ambient temperature.

\subsection{Instrument details}

\subsubsection{Land-based Fourier transform infrared (LA-FTIR) spectrometer}

A rugged, cart-based, mobile FTIR (MIDAC, Inc.) designed to access remote sampling locations (Christian et al., 2007) was used for trace gas measurements. The system can run on battery or generator power. The vibration-isolated optical bench consists of a MIDAC spectrometer with a Stirling cycle cooled mercury-cadmium-telluride (MCT) detector (Ricor, Inc.) interfaced with a closed multipass White cell (Infrared Analysis, Inc.) that is coated with a halocarbon wax (1500 Grade, Halocarbon Products Corp.) to minimize surface losses (Yokelson et al., 2003). In the grab sampling mode used for the FTIR trace gas data reported in this paper, air samples are drawn into the cell by a downstream pump through several meters of $0.635 \mathrm{~cm}$ o.d. corrugated Teflon tubing. The air samples are then trapped in the closed cell by Teflon valves and held for 2-3 min for signal averaging to increase sensitivity. Once the infrared (IR) spectra of a grab sample are logged on the system computer a new grab sample can be obtained. This facilitates collecting many grab samples. Cell temperature and pressure are also logged on the system computer (Minco TT176 RTD, MKS Baratron 722A). Spectra were collected at a resolution of $0.50 \mathrm{~cm}^{-1}$ covering a frequency range of $600-4200 \mathrm{~cm}^{-1}$. Since the last report of the use of this system (Akagi et al., 2013), several upgrades and changes were made: (1) the addition of a retroreflector to the White cell mirrors increased the optical pathlength from 11 to $17.2 \mathrm{~m}$, lowering previous instrument detection limits; (2) renewing the Teflon cell coating with halocarbon wax to maintain good measurements of ammonia $\left(\mathrm{NH}_{3}\right)$, hydrogen chloride $(\mathrm{HCl})$, hydrogen fluo- 
ride (HF), and other species prone to absorption on surfaces; (3) mounting the mirrors to a stable carriage rather than the previous method of gluing them to the cell walls; (4) the abovementioned Stirling cycle detector, which gave the same performance as a liquid-nitrogen-cooled detector without the need for cryogens; (5) the addition of two logged flow meters (APEX, Inc.) and filter holders to enable the system to collect particulate matter on Teflon and quartz filters for subsequent laboratory analyses. The new lower detection limits vary by gas from less than 1 to $\sim 100 \mathrm{ppb}$ and are more than sufficient for near-source ground-based sampling as concentrations are much higher (e.g., ppm range) than in lofted smoke (Burling et al., 2011). Gas-phase species including carbon dioxide $\left(\mathrm{CO}_{2}\right)$, carbon monoxide $(\mathrm{CO})$, methane $\left(\mathrm{CH}_{4}\right)$, acetylene $\left(\mathrm{C}_{2} \mathrm{H}_{2}\right)$, ethylene $\left(\mathrm{C}_{2} \mathrm{H}_{4}\right)$, propylene $\left(\mathrm{C}_{3} \mathrm{H}_{6}\right)$, formaldehyde $(\mathrm{HCHO})$, formic acid $(\mathrm{HCOOH})$, methanol $\left(\mathrm{CH}_{3} \mathrm{OH}\right)$, acetic acid $\left(\mathrm{CH}_{3} \mathrm{COOH}\right)$, furan $\left(\mathrm{C}_{4} \mathrm{H}_{4} \mathrm{O}\right)$, hydroxyacetone $\left(\mathrm{C}_{3} \mathrm{H}_{6} \mathrm{O}_{2}\right)$, phenol $\left(\mathrm{C}_{6} \mathrm{H}_{5} \mathrm{OH}\right), 1,3$-butadiene $\left(\mathrm{C}_{4} \mathrm{H}_{6}\right)$, nitric oxide (NO), nitrogen dioxide $\left(\mathrm{NO}_{2}\right)$, nitrous acid (HONO), $\mathrm{NH}_{3}$, hydrogen cyanide $(\mathrm{HCN}), \mathrm{HCl}$, sulfur dioxide $\left(\mathrm{SO}_{2}\right)$, and $\mathrm{HF}$ were quantified by fitting selected regions of the midIR transmission spectra with a synthetic calibration nonlinear least-squares method (Griffith, 1996; Yokelson et al., 2007). $\mathrm{HF}$ and $\mathrm{HCl}$ were the only gases observed to decay during the several minutes of sample storage in the multipass cell. Thus, for these species, the results are based on retrievals applied separately to the first $10 \mathrm{~s}$ of data in the cell (Yokelson et al., 2003). An upper limit $1 \sigma$ uncertainty for most mixing ratios is $\pm 10 \%$. Post-mission calibrations with NIST-traceable standards indicated that $\mathrm{CO}, \mathrm{CO}_{2}$, and $\mathrm{CH}_{4}$ had an uncertainty between 1 and $2 \%$, suggesting an upper limit on the field measurement uncertainties for $\mathrm{CO}, \mathrm{CO}_{2}$, and $\mathrm{CH}_{4}$ of 3-5\%. The $\mathrm{NO}_{x}$ species have the highest interference from water lines under the humid conditions in Nepal and the uncertainty for $\mathrm{NO}_{x}$ species is $\sim 25 \%$ with the detection limits being near the upper end of the reported range.

In addition to the primary grab sample mode, the FTIR system was also used in a real-time mode to support filter sampling when grab samples were not being obtained. Sideby-side Teflon and quartz fiber filters preceded by cyclones to reject particles with an aerodynamic diameter $>2.5$ microns were followed by logged flow meters. The flow meter output was then combined and directed to the multipass cell where IR spectra were recorded at $\sim 1.1 \mathrm{~s}$ time resolution. In realtime or filter mode we did not employ signal averaging of multiple scans and the signal-to-noise ratio is lower at high time resolution. In addition, there could be sampling losses of sticky species such as $\mathrm{NH}_{3}$ on the filters. However, the data quality is still excellent for $\mathrm{CO}_{2}, \mathrm{CO}$, and $\mathrm{CH}_{4}$. This allowed the time-integrated mass of particle species to be compared to the simultaneously sampled time-integrated mass of $\mathrm{CO}$ and other gases and provided additional measurements of the emissions for these three gases as described in detail in the filter sampling companion paper (Jayarathne et al., 2016).

\subsubsection{Whole-air sampling (WAS) in canisters}

Whole-air samples were collected in evacuated $2 \mathrm{~L}$ stainless steel canisters equipped with a bellows valve and preconditioned by pump-and-flush procedures (Simpson et al., 2006). The canisters were filled to ambient pressure directly in plumes (alternately from the FTIR cell for the zigzag kiln) to enable subsequent measurement and analysis of a large number of gases at UCI (Simpson et al., 2006). Species quantified included $\mathrm{CO}_{2}, \mathrm{CO}, \mathrm{CH}_{4}$, and 93 non-methane organic compounds (NMOCs) by gas chromatography coupled with flame ionization detection, electron capture detection, and quadrupole mass spectrometer detection as discussed in greater detail by Simpson et al. (2011). Peaks of interest in the chromatograms were individually inspected and manually integrated. The limit of detection for most NMOCs that were sampled was $20 \mathrm{pptv}$, which was well below the observed levels. Typically $\sim 60$ WAS NMOCs were enhanced in the source plumes, and we do not report the results for most multiply halogenated species and the higher alkyl nitrates, which are mostly secondary photochemical products. The species we do not report were not correlated with $\mathrm{CO}$ and are generally not emitted directly by combustion (Simpson et al., 2011). Styrene is known to decay in canisters and the styrene data may be lower limits. In total, 96 WAS canisters were sent to Nepal to support the source characterization and ambient monitoring site. Because we anticipated needing canisters for a longer campaign, typically only one emissions sample and one background sample were collected for each source on each day. In total, 48 WAS canisters were filled in all, mostly in April, along with FTIR and other instruments, but some additional source and background measurements were conducted by WAS alone in June after the main campaign. The trace gas measurement techniques used for the reported EFs are indicated in the "method" row near the top of the Supplement and main tables.

\subsubsection{Photoacoustic extinctiometers (PAX) at 405 and $870 \mathrm{~nm}$}

Particle absorption and scattering coefficients $\left(B_{\mathrm{abs}}, B_{\text {scat }}\right.$ $1 / \mathrm{Mm})$ at 405 and $870 \mathrm{~nm}$ were measured directly at $1 \mathrm{~s}$ time resolution using two photoacoustic extinctiometers (PAX, Droplet Measurement Technologies, Inc., CO) and single scattering albedo (SSA), and absorption Ångström exponent (AAE) were calculated from these measurements. This monitored the real-time absorption and scattering resulting from $\mathrm{BC}$ and (indirectly) $\mathrm{BrC}$. The two units were mounted with AC/DC power options, a common inlet, desiccator (Silica Gel), and gas scrubber (Purafil) in rugged, shock-mounted, Pelican military-style hard cases. Air samples were drawn in through conductive tubing followed by $1.0 \mu \mathrm{m}$ size-cutoff cyclones (URG) at $1 \mathrm{~L} \mathrm{~min}^{-1}$. The continuously sampled air is split between a nephelometer and photoacoustic resonator enabling simultaneous measurements of scattering and ab- 
sorption at high time resolution. Once drawn into the acoustic section, modulated laser radiation is passed through the aerosol stream and absorbed by particles in the sample of air. The energy of the absorbed radiation is transferred to the surrounding air as heat and the resulting pressure changes are detected by a sensitive microphone. Scattering coefficients at each wavelength were measured by a wide-angle integrating reciprocal nephelometer, using photodiodes to detect the scattering of the laser light. The estimated uncertainty in absorption and scattering measurements is $\sim 4$ $11 \%$ (Nakayama et al., 2015). Additional details on the PAX instrument can be found elsewhere (Arnott et al., 2006; Nakayama et al., 2015). Due to damage during shipping the PAXs were not available until repaired partway through the campaign and PAX data are therefore not available for a few sources.

Calibrations of the two PAXs were performed frequently during the deployment using the manufacturer recommended scattering and absorption calibration procedures utilizing ammonium sulfate particles and a kerosene lamp to generate pure scattering and strongly absorbing aerosols, respectively. The calibrations of the scattering and absorption of light were directly compared to measured extinction by applying the Beer-Lambert law to laser intensity attenuation in the optical cavity (Arnott et al., 2000). As a quality control measure, we frequently compared the measured total light extinction $\left(B_{\text {abs }}+B_{\text {scat }}\right)$ to the independently measured laser attenuation. For nearly all the $1 \mathrm{~s}$ data checked, the agreement was within $10 \%$ with no statistically significant bias; consistent with (though not proof of) the error estimates in Nakayama et al. (2015). The $405 \mathrm{~nm}$ laser in the PAX has a common nominal wavelength that is usually not measured precisely. After the mission a factory absorption calibration was performed with $\mathrm{NO}_{2}$ gas that was within $1 \%$ of the expected result (Nakayama et al., 2015). As part of this calibration, the laser wavelength was precisely measured as $401 \mathrm{~nm}$. This difference from the nominal $405 \mathrm{~nm}$ wavelength adds $1 \%$ or less uncertainty to the AAE and absorption attribution (Sect. 2.3). We have continued to refer to the wavelength as $405 \mathrm{~nm}$ since this is a standard nominal wavelength for aerosol optical measurements.

\subsubsection{Other measurements}

Two instruments provided $\mathrm{CO}_{2}$ data that were used in the analysis of the PAX data. An ICIMOD Picarro (G2401) cavity ring-down spectrometer measured $\mathrm{CO}_{2}, \mathrm{CO}, \mathrm{CH}_{4}$, and $\mathrm{H}_{2} \mathrm{O}$ in real time. A Drexel LI-COR (LI-820) that was factory calibrated immediately before the campaign also measured $\mathrm{CO}_{2}$ in real time. The sampling inlet of the Picarro and/or LI-COR was colocated with the PAX inlets so that the time-integrated PAX particle data were easily ratioed to time-integrated $\mathrm{CO}_{2}$, allowing straightforward, accurate synthesis of the PAX data with the mobile FTIR and WAS grab sample measurements as described below. A suite of other instruments (mini aerosol mass spectrometer (mAMS); seven wavelength, dual spot aethalometer (model AE33) from Drexel) and the filters employed during the source sampling for subsequent analysis at UI will be described in more detail in companion papers (Jayarathne et al., 2016; Goetz et al., 2016).

\subsection{Emission ratio and emission factor determination}

The excess mixing ratios above the background level (denoted $\Delta X$ for each gas-phase species " $X$ ") were calculated for all gas-phase species. The molar emission ratio (ER) for each gaseous species $X$ relative to $\mathrm{CO}$ or $\mathrm{CO}_{2}$ was calculated for the FTIR and WAS species. For the single WAS sample of any source the ER was simply $\Delta X$ divided by $\Delta C O$ or $\Delta \mathrm{CO}_{2}$. The source-average ER for each FTIR species, typically measured in multiple grab samples, was estimated from the slope of the linear least-squares line (with the intercept forced to zero) when plotting $\Delta X$ vs. $\Delta \mathrm{CO}$ or $\Delta \mathrm{CO}_{2}$ for all samples of the source (Yokelson et al., 2009; Christian et al., 2010). Forcing the intercept effectively weights the points obtained at higher concentrations that reflect more emissions and have greater signal-to-noise ratios so that error is dominated by calibration uncertainty. Alternate data reduction methods usually have little effect on the results as discussed elsewhere (Yokelson et al., 1999). For a handful of species measured by both FTIR and WAS, it is possible to average the ERs from each instrument for a source together, as in Yokelson et al. (2009). However, in this study, due to the large number of FTIR samples $(\sim 5-30)$ and small number of WAS samples (typically one) of each source, we simply used the FTIR ER for "overlap species" (primarily $\mathrm{CH}_{3} \mathrm{OH}$, $\mathrm{C}_{2} \mathrm{H}_{4}, \mathrm{C}_{2} \mathrm{H}_{2}$, and $\mathrm{CH}_{4}$ ).

From the ERs, emission factors (EFs) were derived in units of grams of species $X$ emitted per kilogram of dry biomass burned by the carbon mass balance method, which assumes that all of the major carbon-containing emissions have been measured (Ward and Radke, 1993; Yokelson et al., 1996, 1999):

$$
\begin{aligned}
\mathrm{EF}(X)\left(\mathrm{g} \mathrm{kg}^{-1}\right)= & F_{\mathrm{C}} \times 1000 \times \frac{\mathrm{MM}_{x}}{\mathrm{AM}_{\mathrm{C}}} \\
& \times \frac{\frac{\Delta X}{\Delta \mathrm{CO}}}{\sum_{j=1}^{n}\left(N \mathrm{C}_{j} \times \frac{\Delta \mathrm{C}_{j}}{\Delta \mathrm{CO}}\right)},
\end{aligned}
$$

where $F_{\mathrm{C}}$ is the measured carbon mass fraction of the fuel; $\mathrm{MM}_{x}$ is the molar mass of species $X$; $\mathrm{AM}_{\mathrm{C}}$ is the atomic mass of carbon $\left(12 \mathrm{~g} \mathrm{~mol}^{-1}\right) ; N \mathrm{C}_{j}$ is the number of carbon atoms in species $j ; n$ is the total number of measured species; $\Delta \mathrm{C}_{j}$ or $\Delta X$ referenced to $\Delta \mathrm{CO}$ are the source-average molar emission ratios for the respective species. The carbon fraction was either measured directly (ALS Analytics, Tucson, Table S3) or assumed based on measurements of similar fuel types (Stockwell et al., 2014). The denominator of the last term in Eq. (1) estimates total carbon. Based on many com- 
bustion sources measured in the past, the species $\mathrm{CO}_{2}, \mathrm{CO}$, and $\mathrm{CH}_{4}$ usually comprise 97-99\% of the total carbon emissions (Akagi et al., 2011; Stockwell et al., 2015). Our total carbon estimate includes all the gases measured by both FTIR and WAS in grab samples of a source, and we include the carbon in elemental and organic carbon (ratioed to $\mathrm{CO}$ ) measured during filter sampling. Ignoring the carbon emissions not measurable by our suite of instrumentation (typically higher molecular-weight oxygenated organic gases) likely inflates the EF estimates by less than $\sim 1-2 \%$ (Andreae and Merlet, 2001; Yokelson et al., 2013; Stockwell et al., 2015).

Biomass fire emissions vary naturally as the mix of combustion processes varies. The relative amount of smoldering and flaming combustion during a fire can be roughly estimated from the modified combustion efficiency (MCE). $\mathrm{MCE}$ is defined as the ratio $\Delta \mathrm{CO}_{2} /\left(\Delta \mathrm{CO}_{2}+\Delta \mathrm{CO}\right)$ and is mathematically equivalent to $\left(1 /\left(1+\Delta \mathrm{CO} / \Delta \mathrm{CO}_{2}\right)\right.$ (Yokelson et al., 1996). Flaming and smoldering combustion often occur simultaneously during biomass fires, but a very high MCE $(\sim 0.99)$ designates nearly pure flaming (more complete oxidation), while a lower MCE ( 0.75-0.84 for biomass fuels) designates pure smoldering. Source-averaged MCE was computed for all sources using the source average $\Delta \mathrm{CO} / \Delta \mathrm{CO}_{2}$ ratio as above. In the context of biomass or other solid fuels, smoldering refers to a mix of solid-fuel pyrolysis and gasification (Yokelson et al., 1997) that does not occur in the liquid fuel sources we sampled (e.g., motorcycles, generators, pumps). However, given the large difference in the heat of formation for $\mathrm{CO}_{2}$ and $\mathrm{CO}\left(283 \mathrm{~kJ} \mathrm{~mol}^{-1}\right)$ and $\mathrm{CO}$ being the most abundant carbon-containing emission from incomplete combustion, $\mathrm{MCE}$ and $\Delta \mathrm{CO} / \Delta \mathrm{CO}_{2}$ were useful qualitative probes of their general operating efficiency.

The time-integrated excess $B_{\text {abs }}$ and $B_{\text {scat }}$ from the PAXs were used to directly calculate the source average single scattering albedo (SSA, defined as $\left.B_{\text {scat }} /\left(B_{\text {scat }}+B_{\text {abs }}\right)\right)$ at both 870 and $405 \mathrm{~nm}$ for each source. The PAX time-integrated excess $B_{\text {abs }}$ values at 870 and $405 \mathrm{~nm}$ were used directly to calculate each source-average AAE.

$$
\mathrm{AAE}=-\frac{\log \left(\frac{B_{\mathrm{abs}, 1}}{B_{\mathrm{abs}, 2}}\right)}{\log \left(\frac{\lambda_{1}}{\lambda_{2}}\right)}
$$

Emission factors for $\mathrm{BC}$ and $\mathrm{BrC}$ were calculated from the light absorption measurements made by PAXs at 870 and $405 \mathrm{~nm}$ (described in Sect. 2.2.3). Aerosol absorption is a key parameter in climate models; however, inferring absorption from total attenuation of light by particles trapped on a filter or from the assumed optical properties of a mass measured by thermal or optical processing, incandescence, etc., can sometimes suffer from artifacts (Subramanian et al., 2007). In the PAX, the $870 \mathrm{~nm}$ laser is absorbed in situ by black carbon containing particles only without filter or filter-loading effects that can be difficult to correct. We di- rectly measured aerosol absorption $\left(B_{\mathrm{abs}}, \mathrm{Mm}^{-1}\right)$ and used the manufacturer-recommended mass absorption coefficient (MAC) $\left(4.74 \mathrm{~m}^{2} \mathrm{~g}^{-1}\right.$ at $\left.870 \mathrm{~nm}\right)$ to calculate the BC concentration $\left(\mu \mathrm{g} \mathrm{m}^{-3}\right)$. Our BC mass values are easily scaled if a user feels a different MAC is preferable for one or more sources. The total uncertainty in the MAC is not well known, but the coefficient of variation recommended by the review article our BC MAC is based on is $16 \%$ at $550 \mathrm{~nm}$ for fresh, uncoated combustion aerosol (Bond and Bergstrom, 2006). However, some fresh $\mathrm{BC}$ may have some coating and the assumption of an AAE of 1 to calculate the MAC at $870 \mathrm{~nm}$ is not exact. Overall, $\sim 25-30 \%$ is probably a reasonable "typical" uncertainty, with the error being asymmetric in that we are more likely to overestimate $\mathrm{BC}$ mass due to coating-induced MAC increases. To a good approximation, sp2-hybridized carbon has an AAE of $1.0 \pm 0.2$ and absorbs light proportional to frequency. Thus, $B_{\mathrm{abs}}$ due only to $\mathrm{BC}$ at $405 \mathrm{~nm}$ would be expected to equal $2.148 \times B_{\text {abs }}$ at $870 \mathrm{~nm}$. This assumes that any coating effects are similar at both wavelengths, and it has other assumptions considered reasonably valid, especially in biomass burning plumes by Lack and Langridge (2013). Following these authors, we assumed that excess absorption at $405 \mathrm{~nm}$, above the projected amount, is associated with $\mathrm{BrC}$ absorption, and the $\mathrm{BrC}\left(\mu \mathrm{g} \mathrm{m}^{-3}\right)$ concentration was calculated using a literature-recommended brown carbon MAC of $0.98 \pm 0.45 \mathrm{~m}^{2} \mathrm{~g}^{-1}$ at $404 \mathrm{~nm}$ (Lack and Langridge, 2013). The $\mathrm{BrC}$ mass calculated this way is considered roughly equivalent to the total organic aerosol (OA) mass, which as a whole weakly absorbs UV light, and not the mass of the actual chromophores. The MAC of bulk $\mathrm{OA}$ varies substantially and the $\mathrm{BrC}$ mass we calculate with the single average MAC that we used is only qualitatively similar to bulk OA mass for "average" aerosol and even less similar to bulk OA for non-average aerosol (Saleh et al., 2014). The BrC mass estimated by PAX in this way was independently sampled and worth reporting, but the filters and mAMS provide additional samples of the mass of organic aerosol emissions that have lower per-sample uncertainty for mass. Most importantly, the optical properties from the PAX (SSA, AAE, and absorption EFs calculated as detailed below) are not impacted by MAC variability or filter artifacts. In the case where only a mass emission is reported, a user has to calculate the absorption and scattering with uncertain MAC or mass scattering coefficient values while also retaining any systematic error in the mass measurement, though we note that mass measured by a PAX can always be converted back to absorption (using the same MAC) without adding error. As mentioned above, the PAXs were run in series or in parallel with a $\mathrm{CO}_{2}$ monitor. The mass ratio of $\mathrm{BC}$ and $\mathrm{BrC}$ to the simultaneous colocated $\mathrm{CO}_{2}$, measured by either the Picarro or LI-COR, was multiplied by the FTIR-WAS grab sample $\mathrm{EF}$ for $\mathrm{CO}_{2}$ to determine mass EFs for $\mathrm{BC}$ and $\mathrm{BrC}$ in $\mathrm{g} \mathrm{kg}^{-1}$. From the measured ratios of $B_{\text {abs }}$ and $B_{\text {scat }}$ to $\mathrm{CO}_{2}$, the EFs for scattering and absorption at 870 and $405 \mathrm{~nm}$ (EF $B_{\text {abs }}, \mathrm{EF} B_{\text {scat }}$ ) were calculated and reported in units of 
square meters emitted per kilogram of dry fuel burned. We reiterate that the absorption and scattering EFs do not depend on assumptions about the AAE of BC or MAC values. Both the $\mathrm{CO}_{2}$ and PAX sample were often diluted by using a Dekati Ltd. Axial Diluter (DAD-100), which was factory calibrated to deliver 15.87 SLPM (standard liter per minute) of dilution air at an atmospheric pressure of 1004.6 mbar. Since both instruments samples were diluted by the same amount the dilution factor does not impact the calculation of $\mathrm{PAX} / \mathrm{CO}_{2}$ ratios. On the other hand, the dilution could have some impact on gas-particle partitioning and the mass of $\mathrm{BrC}$ measured. More on the dilution system (and additional aerosol measurements) will be in a forthcoming companion paper (Goetz et al., 2016). Related measurements of elemental and organic carbon on the filters will be discussed by Jayarathne et al. (2016).

\subsection{Emission factors for sources with mixed fuels}

Several of the cooking fires burned a mix of wood and dung, mixed garbage was burned, and the brick kilns co-fired some biomass with the dominant coal fuel. It is not possible to quantify the exact contribution of each fuel to the overall fuel consumption during a specific measurement period or even in total. Thus, for the mixed-fuel cooking fires, we simply assumed an equal amount of wood $(0.45 \mathrm{C})$ and dung $(0.35 \mathrm{C})$ burned and used the average carbon fraction for the two fuels (0.40) (Stockwell et al., 2014; Table S3). For mixed garbage we used a rigorous laboratory carbon content determination (0.50; Stockwell et al., 2014) as opposed to a field determination that relied in part on visual estimates of the amount of components (0.40; Christian et al., 2010). For the zigzag kiln, we used the measured carbon content of the coal (0.722). For the clamp kiln, which likely had more co-fired biomass, we used a weighted carbon content assuming $10 \%$ biomass (at a generic 0.50 carbon content) and $90 \%$ coal (measured carbon content 0.660 ). The weighted average carbon content for the clamp kiln is about $2.5 \%$ lower than for the pure coal. The correction is speculative but in the appropriate direction. The assumed carbon fractions are indicated in each table and the new fuel analyses performed for NAMaSTE for several fuel types are compiled in Table S3. For mixtures differing from those we used, the EFs scale with the assumed carbon fraction.

There are a few unavoidable additional uncertainties in assigning EFs to specific fuels for the brick kilns due to the possibility of emissions from the clay during firing. An estimate of the impact can be made from literature data. Clay typically contains well under $1 \%$ organic material, and some can be lost during firing though residual $\mathrm{C}$ can increase the strength of the fired product and limited permeability makes complete combustion of the $\mathrm{C}$ in the clay difficult to achieve (WattelKoekkoek et al., 2001; Organic Matter in Clay, 2015). For a generous exploratory estimate, we can assume the green bricks are $1 \%$ by mass organic matter that is all $\mathrm{C}$. The brick / coal mass ratio reported by Weyant et al. (2014) is $6-26$, and we take 15 as an average. Overall, $15 \mathrm{~kg}$ of clay at $1 \% \mathrm{C}$ would have $150 \mathrm{~g}$ of $\mathrm{C}$ and $1 \mathrm{~kg}$ of coal at $70 \% \mathrm{C}$ would have $700 \mathrm{gC}$. Thus, if all of the $\mathrm{C}$ in the clay was emitted, it would cause about $18 \%$ of the total C emissions from the production process as an upper limit. The impact on the EF per kilogram coal fuel that we calculated by the carbon mass balance (CMB) method depends on the speciesspecific ER to $\mathrm{CO}_{2}$ in the emissions from the clay $\mathrm{C}$. If the ER for a species due to heating clay $\mathrm{C}$ is the same as burning coal $\mathrm{C}$, then there is no effect on the EF computed by the CMB per kilogram coal even though some of the species is actually coming from the clay. If the ER for "heating" clay $\mathrm{C}$ is much higher or lower than the ER for burning coal $\mathrm{C}$ (e.g., a factor 10), then for some non- $\mathrm{CO}_{2}$ species, we would calculate increases or decreases in the CMB-calculated EFs relative to what actually is produced from the coal fuel. These are only large if a species is emitted mostly from clay combustion (vide infra).

\section{Results and discussion}

\subsection{Overview of aerosol optical properties}

As mentioned above, we measured absorption and scattering coefficients directly and calculated single scattering albedo at 405 and $870 \mathrm{~nm}$. One wavelength-independent SSA value is often assumed for BB aerosol, but we find, as seen previously, that the SSA varies by wavelength for each source (Liu et al., 2014; McMeeking et al., 2014). The AAE is related to the wavelength dependence of the absorption cross section. The AAE for pure BC is assumed to be $\sim 1$, while higher values of AAE indicate relatively more UV absorption and the presence of BrC. Figure 1 plots the source-average AAE vs. the source-average SSA at $405 \mathrm{~nm}$ showing that high AAE is associated with high SSA. In Fig. 1 we show source-averaged AAEs ranging from $\sim 1-5$ and source-averaged SSA values at $405 \mathrm{~nm}$ ranging from $0.37-0.95$ for the sources tested in this study. The error bars are 1 standard deviation of the average for each source type sampled more than once. The "highAAE" sources appearing toward the upper right-hand corner (e.g., dung and open wood cooking, clamp kiln) are associated with significant light absorption that would be overlooked by a consideration of $\mathrm{BC}$ alone. We note that both PAXs were not operational during the generator and motorcycle sampling days, and the PAX 870 was not operational during the irrigation pump sampling and for several garbage burns. We assumed that the pumps emitted only BC (this assumption is supported by the very low SSA) and used the MAC of BC at $405 \mathrm{~nm}\left(10.19 \mathrm{~m}^{2} \mathrm{~g}^{-1}\right)$ to calculate BC for this one source (Bond and Bergstrom, 2006). Both PAXs were operational for only one garbage burn, which had a low AAE near 1. Additional data from the aethalometer and filters, including for tests where one or both PAXs were not op- 


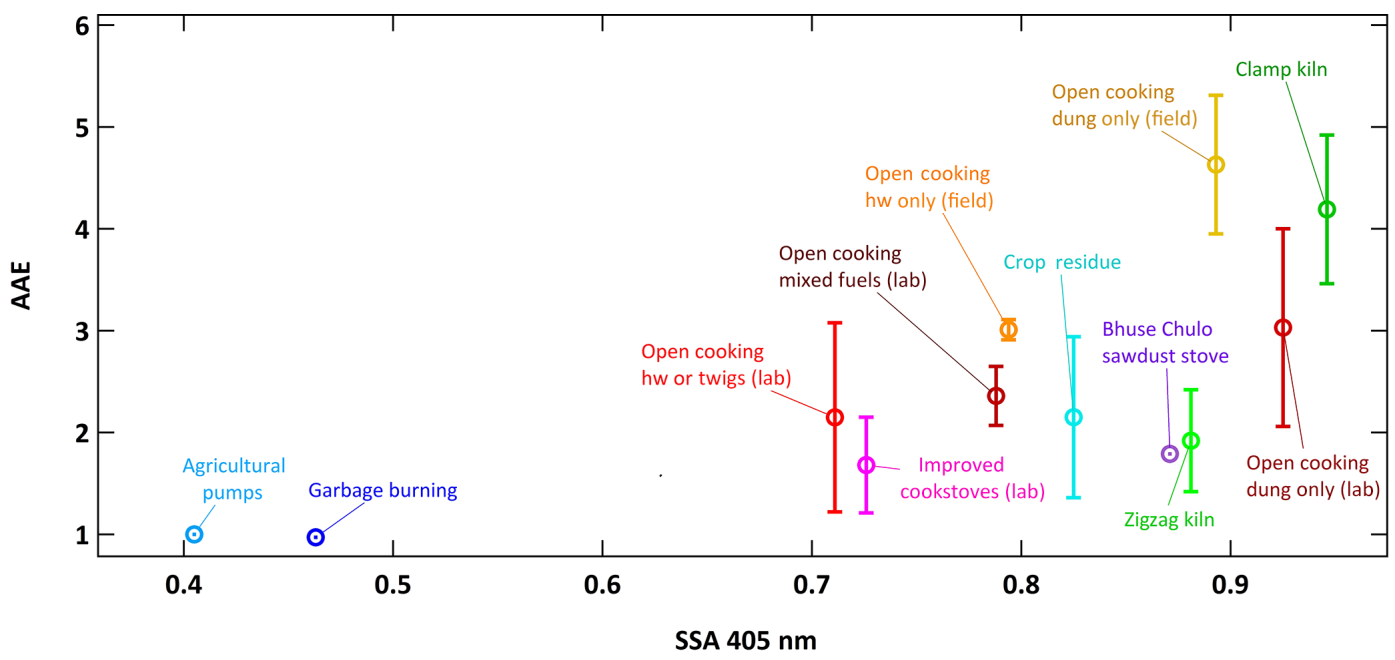

Figure 1. The absorption Ångström exponent (AAE) calculated at 405 and $870 \mathrm{~nm}$ as a function of single scattering albedo (SSA) at $405 \mathrm{~nm}$ for fuel types measured during the NAMaSTE campaign. The error bars represent \pm 1 standard deviation of the AAE measured for different burns (or different samples in the case of brick kilns). Note: "hw" indicates hardwood fuels. The AAE for agricultural pumps was not measured but is assumed to be 1 because the SSA at $405 \mathrm{~nm}$ was indicative of pure BC. AAE was only measured on one garbage burning fire (value of 0.971) though the SSA at $405 \mathrm{~nm}$ on another garbage burning fire indicates that its AAE was larger than 1 .

erational, will be presented in companion papers (Jayarathne et al., 2016; Goetz et al., 2016).

It is important to consider the differences in optical properties for the aerosol emitted by the various biofuel-stove combinations used in this understudied region with high levels of biofuel use. Dung-fired cooking had a significantly higher AAE $(4.63 \pm 0.68)$ than cooking with hardwood $(3.01 \pm 0.10)$. The AAE is also generally lower for improved stove types $(1.68 \pm 0.47)$ when compared to traditional open cooking (i.e., without an insulated combustion chamber) (Fig. 1). In general, the optical properties vary significantly by fuel type and the mix of combustion processes. As established in previous studies (e.g., Christian et al., 2003; Liu et al., 2014), BC is emitted by flaming combustion and $\mathrm{BrC}$ is emitted primarily during smoldering combustion, and both can contribute strongly to the total overall absorption. Thus, the fuels that burned at a higher average MCE usually produced relatively more $\mathrm{BC}$, which is also reflected in lower AAE and SSA values. These trends are similar to those observed during the third and fourth Fire Lab at Missoula Experiment (FLAME-3, -4) (Lewis et al., 2008; McMeeking et al., 2014; Liu et al., 2014). Additional PAX results will be discussed by fuel type along with the trace gas results in the following sections.

\subsection{Motorcycle emissions}

The average EFs $\left(\mathrm{g} \mathrm{kg}^{-1}\right)$ based on FTIR and WAS for the pre- and post-service fleet are shown in Table 1, and bikespecific pre and post results are included in Supplement Table $\mathrm{S} 4$. As a fleet, we found that after servicing, MCE, $\mathrm{NO}_{x}$, and most NMOCs were slightly reduced and CO slightly in-
Table 1. Fleet average emission factors $\left(\mathrm{g} \mathrm{kg}^{-1}\right)$ and standard deviation for two-wheeled vehicle measurements.

\begin{tabular}{lrr}
\hline Compound (formula) & $\begin{array}{r}\text { EF pre-service } \\
\text { fleet avg }(\mathrm{SD})\end{array}$ & $\begin{array}{r}\text { EF post-service } \\
\text { fleet avg }(\mathrm{SD})\end{array}$ \\
\hline Method & FTIR & FTIR \\
MCE & 0.619 & 0.601 \\
Carbon dioxide $\left(\mathrm{CO}_{2}\right)$ & $1846(690)$ & $1816(562)$ \\
Carbon monoxide $(\mathrm{CO})$ & $710(389)$ & $761(327)$ \\
Methane $\left(\mathrm{CH}_{4}\right)$ & $7.60(7.24)$ & $6.74(4.54)$ \\
Acetylene $\left(\mathrm{C}_{2} \mathrm{H}_{2}\right)$ & $11.7(11.1)$ & $7.89(5.83)$ \\
Ethylene $\left(\mathrm{C}_{2} \mathrm{H}_{4}\right)$ & $13.2(3.9)$ & $11.4(4.2)$ \\
Propylene $\left(\mathrm{C}_{3} \mathrm{H}_{6}\right)$ & $3.32(0.75)$ & $2.58(1.03)$ \\
Formaldehyde $(\mathrm{HCHO})$ & 0.548 & 0.535 \\
Methanol $\left(\mathrm{CH}_{3} \mathrm{OH}\right)$ & bdl & bdl \\
Formic acid $(\mathrm{HCOOH})$ & $9.57 \times 10^{-2}$ & $5.95 \times 10^{-2}$ \\
& $\left(3.57 \times 10^{-2}\right)$ & $\left(1.84 \times 10^{-2}\right)$ \\
Acetic acid $\left(\mathrm{CH}_{3} \mathrm{COOH}\right)$ & bdl & bdl \\
Glycolaldehyde $\left(\mathrm{C}_{2} \mathrm{H}_{4} \mathrm{O}_{2}\right)$ & bdl & bdl \\
Furan $\left(\mathrm{C}_{4} \mathrm{H}_{4} \mathrm{O}\right)$ & bdl & bdl \\
Hydroxyacetone $\left(\mathrm{C}_{3} \mathrm{H}_{6} \mathrm{O}_{2}\right)$ & $2.10(3.18)$ & $2.41(0.99)$ \\
Phenol $\left(\mathrm{C}_{6} \mathrm{H}_{5} \mathrm{OH}\right)$ & $4.84(3.55)$ & $3.02(2.29)$ \\
1,3-Butadiene $\left(\mathrm{C}_{4} \mathrm{H}_{6}\right)$ & $1.30(0.51)$ & $1.19(0.56)$ \\
Isoprene $\left(\mathrm{C}_{5} \mathrm{H}_{8}\right)$ & bdl & bdl \\
Ammonia $\left(\mathrm{NH}_{3}\right)$ & $0.113(0.034)$ & $0.032(0.023)$ \\
Hydrogen cyanide $(\mathrm{HCN})$ & $0.841(0.428)$ & $0.678(0.174)$ \\
Nitrous acid $(\mathrm{HONO})$ & bdl & bdl \\
Sulfur dioxide $\left(\mathrm{SO}_{2}\right)$ & bdl & bdl \\
Hydrogen fluoride $(\mathrm{HF})$ & bdl & bdl \\
Hydrogen chloride $(\mathrm{HCl})$ & bdl & bdl \\
Nitric oxide $\left(\mathrm{NO}^{2}\right)$ & $2.94(2.39)$ & $1.89(0.81)$ \\
Nitrogen dioxide $\left(\mathrm{NO}_{2}\right)$ & bdl & bdl \\
\hline Note: "bdl” indicates below the detection limit; C fraction: $0.85-$ source is Kirchstetter \\
et al. (1999). & &
\end{tabular}


creased; however, these fleet-average changes are not statistically significant given the high variability in EF. Interestingly, for individual motorbike-specific comparisons (Table S4), in four out of five bikes, the MCE actually decreased after servicing, indicating less efficient (though not necessarily less "clean") combustion, but this result is not statistically significant. To ensure that effects such as background drift did not cause this result, we verified that the same results occur when obtaining slopes from plots using absolute (i.e., not background-corrected) mixing ratios. A similar lack of reduction in gas-phase pollutants has been reported in the literature following repair and maintenance (Chiang et al., 2008) and has been attributed to the complexity in adjusting carburetors to optimal combustion conditions (Escalambre, 1995). Our high CO emissions did not always correlate with high hydrocarbon emissions. While we do not know the exact cause of this, this effect has been seen in other vehicle studies with a variety of explanations (Beaton et al., 1992; Zhang et al., 1995). While the gaseous pollutants were not significantly reduced post-service, the fleet's total particulate emissions did decrease significantly, and we refer to Jayarathne et al. (2016) for a detailed comparison.

$\mathrm{CO}$ had the highest emissions of any gas after $\mathrm{CO}_{2}$, and the FTIR-measured average EFs pre- and post-service over $700 \mathrm{~g} \mathrm{~kg}^{-1}$ are about 10 times the typical EF for CO observed in BB. The FTIR-measured average MCE for the postservice motorcycles was $\sim 0.60$, equivalent to a $\mathrm{CO} / \mathrm{CO}_{2}$ molar ER of $\sim 0.66$, dramatically highlighting the poor efficiency of the engines. We were initially surprised by this result, but it is confirmed by WAS in that the one WAS sample of start-up and idling emissions returned a $\mathrm{CO} / \mathrm{CO}_{2} \mathrm{ER}$ (0.789) that is within the FTIR-sample range. In fact, even higher $\mathrm{CO} / \mathrm{CO}_{2}$ ERs (3.2-4.2) are generated for the start-up of motorcycles in the IVE model, which is based on sampling in developing countries (Oanh et al., 2012; Shrestha et al., 2013). Of 11227 vehicles of all types tested by remote sensing during on-road use in Kathmandu in 1993, about 2000 had a $\mathrm{CO} / \mathrm{CO}_{2}$ ER higher than 0.66 (fleet average 0.39, range 0-3.8, Zhang et al., 1995).

The next most abundant emissions after $\mathrm{CO}$ were $\mathrm{C}_{2}$ hydrocarbons $\left(\sim 24 \mathrm{~g} \mathrm{~kg}^{-1}\right)$, BTEX (benzene, toluene, ethylbenzene, and xylenes) compounds $\left(\sim 15 \mathrm{~g} \mathrm{~kg}^{-1}\right)$ and then the sum of measured oxygenated volatile organic compounds (OVOCs) and $\mathrm{CH}_{4}$ each at $\sim 7 \mathrm{~g} \mathrm{~kg}^{-1}$. The OVOC from this source were mostly phenol, hydroxyacetone, and acetone (Tables 1 and S4). The BTEX and acetone data are from the one motorcycle that was analyzed by WAS pre-service. The WAS provided several overlap species with the FTIR and many additional non-methane hydrocarbons (NMHCs) not measured by FTIR. First, we note, in agreement with the FTIR, that ethylene and acetylene were the most abundant WAS NMHC species and that they accounted for $\sim 38 \%$ of the total WAS NMHC emissions. The acetylene-to-ethylene ratio in this sample was 0.45 , which is similar to previous roadside studies of all traffic (Tsai et al., 2006; Ho et al., 2009). Significantly, the WAS sample showed high concentrations of BTEX compounds, some of which are important carcinogens and all of which can lead to significant secondary organic aerosol (SOA) production (Platt et al., 2014). Toluene is a common gasoline additive and is sometimes used as a tracer for gasoline evaporation (Tsai et al., 2006). However, in our motorcycle data, aromatics account for $\sim 31 \%$ of the NMHC in the exhaust emissions, with toluene being the most abundant aromatic. Platt et al. (2014) measured BTEX emission factors from about 10 to $100 \mathrm{~g} \mathrm{~kg}^{-1}$ (a range for driving to idling) for twostroke motor scooter exhaust, also finding that toluene was the most abundant aromatic and with the BTEX accounting for $\sim 40 \%$ of VOC. The combustion process in motorcycle engines is generally less efficient than in automobile engines (Platt et al., 2014), and the incomplete combustion can lead to emissions of many NMHC components in the gasoline. For instance, the exhaust emissions of branched $\mathrm{C}_{5}-\mathrm{C}_{6}$ alkanes, including 2-methylpentane and $i$-pentane (sometimes a tracer for gasoline evaporation; Morikawa et al., 1998; Guo et al., 2006) were also significant in the motorcycle exhaust. Previous studies also found that the VOC emission profile from motorcycle exhaust was similar to gasoline headspace analysis (Liu et al., 2008). In summary, inefficient motorcycle engines produce exhaust containing a suite of NMHCs that overlaps with those produced by fuel evaporation. However, there may be significant variability in headspace and exhaust measurements as observed by Lyu et al. (2016).

The air toxic and common BB tracer HCN was emitted by the motorcycles at about $1 / 10$ the ER to CO typically measured for BB. However, because of the very high motorcycle $\mathrm{CO}$ emissions, the $\mathrm{EF}$ for $\mathrm{HCN}$ for motorcycles was actually similar to that for BB. This is of importance for health effects and the use of HCN as a BB tracer in urban areas (Moussa et al., 2016), especially in developing countries where motorcycles are prevalent (Yokelson et al., 2007; Crounse et al., 2009). A few other emissions stood out in the dataset, including high emissions of 1,3-butadiene $\left(\sim 1.3 \mathrm{~g} \mathrm{~kg}^{-1}\right)$. While 1,3-butadiene is not a component of gasoline, it is a known component of vehicle exhaust (e.g., Duffy and Nelson, 1996) and is believed to originate from the combustion of olefins (Perry and Gee, 1995). The EPA has highlighted 1,3-butadiene as having the highest cancer risk of air toxics emitted by US motor vehicles (USEPA, 1993), and exposure in densely populated urban centers can have significant negative health impacts.

One scooter was sampled by FTIR during this campaign and the $\mathrm{CO}$ emissions of the smaller scooter engine were only one fourth to one half those of the motorcycles (Table S4). The scooter exhaust emissions were also significantly lower for most other species captured by FTIR. The scooter, however, was the only motorbike sampled that produced detectable formaldehyde, a known carcinogen, irritant, and important radical precursor in urban atmospheres (Vaughan et al., 1986; Volkamer et al., 2010). 
It is important to note that the average EFs from this study are not intended to represent the entire Kathmandu fleet of vehicles (or even all motorcycle use) as there is significant emissions variability between vehicles depending on running conditions (road conditions, driving patterns, maintenance, emissions control technology; Holmén and Niemeier, 1998; Popp et al., 1999) and engine specifics (model, size, age, power, fuel composition, combustion temperature and pressure, etc.; Zachariadis et al., 2001; Zavala et al., 2006). Larger studies similar to Zhang et al. (1995) are needed to get fleet averages. However, motorcycles and motor scooters have been identified as major contributors to transport sector pollution in Kathmandu (Shrestha et al., 2013) and elsewhere (Oanh et al., 2012; Platt et al., 2014), and we provide chemically detailed real-world EFs for motorcycles under some common operating conditions that were previously unmeasured in Kathmandu.

Because of the diversity in fleet characteristics and how operating conditions are subdivided, it is difficult to compare our results to other studies, but some of the species we measured are explicitly provided in other vehicle emissions estimates (Oanh et al., 2012; Shrestha et al., 2013; Platt et al., 2014). Probably the most direct comparison is with Oanh et al. (2012), who reported EFs (in $\mathrm{g} \mathrm{km}^{-1}$ ) specifically for motorcycles for both start-up and running for the Hanoi 2008 average fleet based on the IVE that included some overlap species with our study $\left(\mathrm{NO}_{x}, \mathrm{CH}_{4}\right.$, acetaldehyde, formaldehyde, benzene, and 1,3-butadiene). Except for 1,3-butadiene our average ratios to $\mathrm{CO}$ for these species for start-up and idling are only 3-26\% of theirs for start-up or running. Zhang et al. (1995) noted that partially functional catalytic converters convert VOC to $\mathrm{CO}$ (rather than $\mathrm{CO}_{2}$ ) lowering the VOC / CO ratio and also that these devices were becoming more common in the overall Kathmandu fleet, which points to emission control technology as a source of variability. The motorcycles we tested were all four-stroke and built by some of the world's largest manufacturers in India, where catalytic converters are required on two-stroke vehicles but were not required for four-stroke bikes until 2015. The Indian motorcycle emissions standards are based on an idling test and become increasingly stringent every 5 years (factor of 14.25 reduction for CO from 1991 to 2010). In response, a variety of emission control measures are incorporated in the motorcycle engines to reduce "engine out" emissions as opposed to "after treatment". Some of these measures are described in detail by Iyer (2012), while others are proprietary. The durability of many of these measures is very low (Ntziachristos et al., 2006, 2009), meaning they deteriorate with age despite minor service. Fuel quality (adulteration) is also noted as a widespread issue for emissions control (Iyer, 2012). In summary, it is quite possible that our VOC / CO ratios are lower than Oanh et al. (2012), mostly because of increased prevalence of emissions control technology (although poorly maintained) in Kathmandu in 2015 compared to Hanoi in 2008.
In general, our emission ratios can be used with, e.g., $\mathrm{CO}$ EFs from other studies to roughly estimate additional chemical details for operating conditions we did not sample. It is also interesting that we observed that the emitted gases did not change significantly after servicing. It is possible that gas-phase pollutants would have decreased postservice under "cruising" conditions, but we were limited to testing start-up and idling emissions. A study in Hong Kong found that replacing old catalytic converters had a large impact on emissions, but minor servicing did not (Lyu et al., 2016). Thus, major servicing might be required to mitigate gas-phase pollutants in general. Finally, our filter results suggested that the particulate matter (PM) emissions were reduced post-service (Jayarathne et al., 2016). Therefore, it is likely that minor servicing of motorcycles is beneficial if it reduces the PM without making the vast majority of the gases significantly worse. The EFs (in $\mathrm{g} \mathrm{kg}^{-1}$ ) here could theoretically be converted to fuel-based EFs $\left(\mathrm{g} \mathrm{km}^{-1}\right)$ using a conversion factor based on motorcycle fuel economy. However, this is a complex process in practice (Clairotte et al., 2012), and it would probably be more meaningful to combine our ER to CO with fuel-based CO emission factors measured under the appropriate conditions.

\subsection{Generator emissions}

Three generators (two diesel and one gasoline) were sampled about $1 \mathrm{~m}$ downstream of the exhaust manifold and the EFs are shown in Table S5. The larger diesel generator located on the ICIMOD campus is professionally maintained and had a much smaller EF CO $\left(4.10 \mathrm{~g} \mathrm{~kg}^{-1}\right)$ and a higher MCE (0.998) than the smaller (rented) diesel generator (MCE 0.962 ; EF CO $76.1 \mathrm{~g} \mathrm{~kg}^{-1}$ ). The smaller rented diesel generator had 18-150 times higher emissions for the five non$\mathrm{CO}_{2}$ gases measured from both sources. The one gasoline generator we sampled had much higher $\mathrm{CO}$ emissions $\left(>1000 \mathrm{~g} \mathrm{~kg}^{-1}\right)$ and was much less efficient (MCE 0.437) than both diesel generators. This is similar to the gasolinepowered motorcycles discussed in Sect. 3.2 that also had high EFs for $\mathrm{CO}\left(>700 \mathrm{~g} \mathrm{~kg}^{-1}\right)$ with generally low MCEs.

Not surprisingly, the one diesel generator sampled by FTIR (the small rental) did emit high concentrations of $\mathrm{NO}_{x}$ $\left(\sim 24 \mathrm{~g} \mathrm{~kg}^{-1}\right)$, while $\mathrm{NO}_{x}$ emissions remained below the detection limit for the gasoline-powered generator sampled by FTIR (Vestreng et al., 2009). NO is the main form of fresh combustion $\mathrm{NO}_{x}$, but it is converted to $\mathrm{NO}_{2}$ within minutes and peroxyacetyl nitrate and nitrate within a few hours (affecting aerosol and $\mathrm{O}_{3}$ levels) as discussed elsewhere (Akagi et al., 2013; Liu et al., 2016). The gasoline-powered generator emitted more NMHCs than both diesel generators and likely produces high secondary aerosol that has been observed in gasoline vehicle emission studies (Platt et al., 2013). We measured gasoline generator BTEX emissions that were $\sim 20$ times greater than those from the large diesel generator and note that the SOA yields from the photooxi- 
dation of $m$-xylene, toluene, and benzene are significant $(\mathrm{Ng}$ et al., 2007). We were able to measure $\mathrm{HCHO}$ emissions by FTIR from the small diesel generator $\left(2.75 \mathrm{~g} \mathrm{~kg}^{-1}\right)$ and the gasoline generator $\left(0.61 \mathrm{~g} \mathrm{~kg}^{-1}\right)$. Even though the diesel generator ran much more cleanly overall (for gas-phase pollutants), it produced significantly more HCHO than the gasoline generator and we recall that $\mathrm{HCHO}$ was below the detection limit for the gasoline-powered motorcycles we measured. This suggests that diesel may tend to produce higher $\mathrm{HCHO}$ emissions than gasoline. As mentioned in Sect. 3.2, $\mathrm{HCHO}$ is an air toxic and is important in atmospheric chemistry. Overall, OVOCs were not clearly associated with either fuel, with the gasoline generator having higher EFs for acetaldehyde, acetone, phenol, and furan but lower EFs for $\mathrm{HCHO}$ and organic acids.

Other evident differences between the generators were potentially based on fuel. The large well-maintained diesel generator emitted more of the heavier NMHCs including heptane, octane, nonane, decane, and methylcyclohexane than the lesser-maintained gasoline generator. The gasoline generator had much higher EFs for the smaller-chain NMHCs $\left(\mathrm{C}_{2} \mathrm{H}_{2}, \mathrm{C}_{2} \mathrm{H}_{4}, \mathrm{C}_{2} \mathrm{H}_{6}, \mathrm{C}_{3} \mathrm{H}_{6}\right.$, etc. $)$. While the diesel fuel generators we sampled burned more cleanly overall in terms of gas-phase pollutants, diesel is normally considered a much dirtier fuel in terms of soot production. The two PAX instruments were not operational for sampling generators, but filters were collected and demonstrated a higher EF PM for the small diesel generator than the gasoline generator, as will be highlighted by Jayarathne et al. (2016).

We were able to sample both the smaller diesel generator and the gasoline generator during both start-up and freerunning conditions. The diesel generator produced concentrations about twice as high for most measured species during start-up as opposed to free-running conditions, while the gasoline-fueled generator did not show these start-up concentration spikes. Sharp emission spikes peaking during both cold and hot start-ups of diesel engines have been observed previously (Gullet et al., 2006). This is often attributed to periods of incomplete combustion during ignition and could have significant impacts on air quality as power cuts are a frequent, intermittent occurrence throughout the valley.

In summary, the well-maintained diesel generator had much lower EFs for most overlapping gases measured (except large alkanes, which were a minor overall component), but gasoline could have advantages in terms of $\mathrm{NO}_{x}$ and PM emissions at the cost of increases in most other pollutants unless they could be reduced by better maintenance. Although vehicular emissions are most commonly reported, emissions from gasoline- and diesel-powered generators can also have large impacts in urban regions subject to significant load shedding, which is relevant throughout Nepal and especially in the Kathmandu Valley (World Bank, 2014).

\subsection{Agricultural diesel pump emissions}

In this study, two groundwater irrigation diesel pumps were sampled by FTIR and the EFs are reported in Table 2. In addition, a surface-water irrigation pump was sampled by WAS canisters only and showed massively higher $\mathrm{CO}$ emissions than the two other pumps in our study indicating that it was probably gasoline-powered. The WAS data may be mainly of interest to characterize old or poorly maintained pumps and the EFs are included in Supplement Table S6.

For the two diesel pumps sampled by FTIR, the grab samples during cold start-up differed from the samples during regular continuous operation by a much larger degree than the variability in grab samples for the other sources, so we computed EF by two methods. Method one is our standard approach based on the ER plot using all the samples. The start-up emissions can be outliers in this approach and get lower weight accordingly. Thus, we also computed ERs from the sum of the individual ERs and used those to generate a second set of EF that weights the start-up emissions more. Our standard approach yields the EFs shown in Table 2, columns 2 and 4, with an average of those two columns in column 6. We have included columns 3 and 5 with EFs calculated from the sum of excess emissions that emphasizes startup more. The alternate EF calculation reflects the increased emission of hydrocarbon species during ignition. $\mathrm{CO}$ also increases substantially, while $\mathrm{NO}_{x}$ decreases slightly. We believe the most representative EFs for model input are taken from the standard approach that does not add weight to the start-up conditions, as most pumps are likely operated over longer periods of time. However, all the data are provided, should a user prefer a different approach.

Although the $870 \mathrm{~nm}$ PAX was not operational on this day, the EFs $\left(\mathrm{m}^{2} \mathrm{~kg}^{-1}\right)$ of $B_{\text {abs }}$ and $B_{\text {scat }}$ for aerosols measured at $405 \mathrm{~nm}$ and the SSA are reported in Table 2 for the complete sampling cycle. The SSA at $405 \mathrm{~nm}(0.405 \pm 0.137)$ indicates that the diesel pump emissions were dominated by strongly absorbing aerosols, and if we assume there are no $\mathrm{BrC}$ emissions from this source, a reasonable assumption supported by the AE33 data, the absorption at $405 \mathrm{~nm}$ can be used to get a rough estimate for EF BC. The average EF BC $\left(5.72 \pm 0.58 \mathrm{~g} \mathrm{~kg}^{-1}\right)$ is very high compared to typical values closer to $1 \mathrm{~g} \mathrm{~kg}^{-1}$ for most sources.

From the average emissions in Table 2, we see that the two pumps sampled by FTIR were not as prolific emitters for most pollutants as many other sources sampled in this study. However, the emissions of $\mathrm{NO}_{x}$ and absorbing aerosol were comparatively high. Especially taken together, the emissions from diesel-powered generators and agricultural water pumps are likely significant in both urban and rural regions of Nepal and should be included in updated emissions inventories. 
Table 2. Emission factors $\left(\mathrm{g} \mathrm{kg}^{-1}\right)$ for agricultural diesel irrigation pumps including EFs weighting only start-up emissions.

\begin{tabular}{|c|c|c|c|c|c|}
\hline Compound (formula) & EF Ag pump 1 & $\begin{array}{r}\text { EF Ag pump } 1 \\
\text { emphasize start-up }\end{array}$ & EF Ag pump 2 & $\begin{array}{r}\text { EF Ag pump } 2 \\
\text { emphasize start-up }\end{array}$ & $\begin{array}{r}\text { EF Ag pumps } \\
\text { avg (SD) }\end{array}$ \\
\hline Method & FTIR & FTIR & FTIR & FTIR & - \\
\hline MCE & 0.987 & 0.974 & 0.996 & 0.990 & 0.992 \\
\hline Carbon dioxide $\left(\mathrm{CO}_{2}\right)$ & 3103 & 3038 & 3161 & 3133 & $3132(41)$ \\
\hline Carbon monoxide (CO) & 26.0 & 51.3 & 7.36 & 20.2 & $16.7(13.2)$ \\
\hline Methane $\left(\mathrm{CH}_{4}\right)$ & 3.80 & 6.14 & 1.41 & 2.85 & $2.61(1.69)$ \\
\hline Acetylene $\left(\mathrm{C}_{2} \mathrm{H}_{2}\right)$ & 0.413 & 2.18 & 0.08 & 0.748 & $0.246(0.237)$ \\
\hline Ethylene $\left(\mathrm{C}_{2} \mathrm{H}_{4}\right)$ & 5.37 & 9.15 & 1.47 & 3.04 & $3.42(2.75)$ \\
\hline Propylene $\left(\mathrm{C}_{3} \mathrm{H}_{6}\right)$ & 1.85 & 3.26 & 0.424 & 0.894 & $1.14(1.01)$ \\
\hline Formaldehyde (HCHO) & 0.506 & 1.23 & $5.29 \times 10^{-2}$ & 0.175 & $0.280(0.320)$ \\
\hline Methanol $\left(\mathrm{CH}_{3} \mathrm{OH}\right)$ & $3.59 \times 10^{-2}$ & 0.119 & $5.77 \times 10^{-3}$ & $1.33 \times 10^{-2}$ & $\begin{array}{c}2.08 \times 10^{-2} \\
\left(2.13 \times 10^{-2}\right)\end{array}$ \\
\hline Formic acid $(\mathrm{HCOOH})$ & bdl & bdl & bdl & bdl & bdl \\
\hline Acetic acid $\left(\mathrm{CH}_{3} \mathrm{COOH}\right)$ & bdl & bdl & bdl & bdl & bdl \\
\hline Glycolaldehyde $\left(\mathrm{C}_{2} \mathrm{H}_{4} \mathrm{O}_{2}\right)$ & bdl & bdl & bdl & bdl & bdl \\
\hline Furan $\left(\mathrm{C}_{4} \mathrm{H}_{4} \mathrm{O}\right)$ & bdl & bdl & bdl & bdl & bdl \\
\hline Hydroxyacetone $\left(\mathrm{C}_{3} \mathrm{H}_{6} \mathrm{O}_{2}\right)$ & bdl & bdl & bdl & bdl & bdl \\
\hline Phenol $\left(\mathrm{C}_{6} \mathrm{H}_{5} \mathrm{OH}\right)$ & 0.449 & 0.583 & 0.117 & 0.258 & $0.283(0.235)$ \\
\hline 1,3-Butadiene $\left(\mathrm{C}_{4} \mathrm{H}_{6}\right)$ & 0.809 & 1.47 & 0.194 & 0.399 & $0.501(0.435)$ \\
\hline Isoprene $\left(\mathrm{C}_{5} \mathrm{H}_{8}\right)$ & $1.55 \times 10^{-2}$ & $7.20 \times 10^{-2}$ & $1.93 \times 10^{-2}$ & $2.30 \times 10^{-2}$ & $\begin{array}{c}1.74 \times 10^{-2} \\
\left(2.69 \times 10^{-3}\right)\end{array}$ \\
\hline Ammonia $\left(\mathrm{NH}_{3}\right)$ & $9.27 \times 10^{-3}$ & $6.42 \times 10^{-2}$ & $1.32 \times 10^{-3}$ & $1.32 \times 10^{-3}$ & $\begin{array}{c}5.29 \times 10^{-3} \\
\left(5.62 \times 10^{-3}\right)\end{array}$ \\
\hline Hydrogen cyanide (HCN) & 0.188 & 0.458 & $4.77 \times 10^{-2}$ & 0.282 & $0.118(0.099)$ \\
\hline Nitrous acid (HONO) & 0.348 & 0.307 & 0.346 & 0.373 & $0.347(0.001)$ \\
\hline Sulfur dioxide $\left(\mathrm{SO}_{2}\right)$ & bdl & bdl & bdl & bdl & bdl \\
\hline Hydrogen fluoride (HF) & bdl & bdl & bdl & bdl & bdl \\
\hline Hydrogen chloride $(\mathrm{HCl})$ & bdl & bdl & bdl & bdl & bdl \\
\hline Nitric oxide (NO) & 5.31 & 5.09 & 15.9 & 15.7 & $10.6(7.5)$ \\
\hline Nitrogen dioxide $\left(\mathrm{NO}_{2}\right)$ & 2.19 & 1.86 & 1.20 & 1.15 & $1.69(0.70)$ \\
\hline EF black carbon $(\mathrm{BC})$ & 6.13 & - & 5.31 & - & $5.72(0.58)$ \\
\hline $\mathrm{EF} B_{\mathrm{abs}} 405 \mathrm{~nm}\left(\mathrm{~m}^{2} \mathrm{~kg}^{-1}\right)$ & 62.4 & - & 54.1 & - & $58.3(5.9)$ \\
\hline EF $B_{\text {scat }} 405 \mathrm{~nm}\left(\mathrm{~m}^{2} \mathrm{~kg}^{-1}\right)$ & 62.9 & - & 24.0 & - & $43.4(27.5)$ \\
\hline SSA $405 \mathrm{~nm}$ & 0.502 & - & 0.307 & - & $0.405(0.137)$ \\
\hline
\end{tabular}

Note: "bdl" indicates below the detection limit; C fraction: 0.85 - source is Kirchstetter et al. (1999).

\subsection{Garbage burning emissions}

For an overview of our Nepal garbage burning (GB) data that also allows us to compare to authentic field- and labmeasured GB, we tabulated (Table S7) our study-average Nepal mixed GB EFs along with mixed GB EFs from two lab studies (Yokelson et al., 2013; Stockwell et al., 2015), field measurements of open GB in Mexican landfills (Christian et al., 2010), and a single airborne sample of a Mexican dump fire (Yokelson et al., 2011). Figure 2 displays the major emissions from these studies in order of their abundance in the NAMaSTE data. We observe an interesting mix of compounds usually associated with burning biomass (OVOCs) and fossil fuels (NMHC and BTEX) as well as nitrogen and chlorine compounds. Even though the methodology and locales varied considerably, the EFs reported in each study show reasonable agreement for most overlap compounds (Fig. 2). The average EFs of smoldering compounds for mixed-garbage burns in Nepal were generally slightly higher than the other studies and the average MCE was lower (0.923, range in MCE 0.864-0.980). This is consistent with observations by several coauthors that flaming-dominated GB is more common in winter months in Nepal when GB also provides heat. The comparison also suggests that the lab results for compounds not measured in the field (e.g., Yokelson et al., 2013; Stockwell et al., 2015) could be used if scaled with caution. The NAMaSTE-specific EFs for garbage burning are reported for each fire in Table 3 along with our study average for mixed GB EFs, and we discuss some emissions next.

The laboratory mixed-garbage burning experiments during FLAME-4 were the first to yield a glycolaldehyde EF 


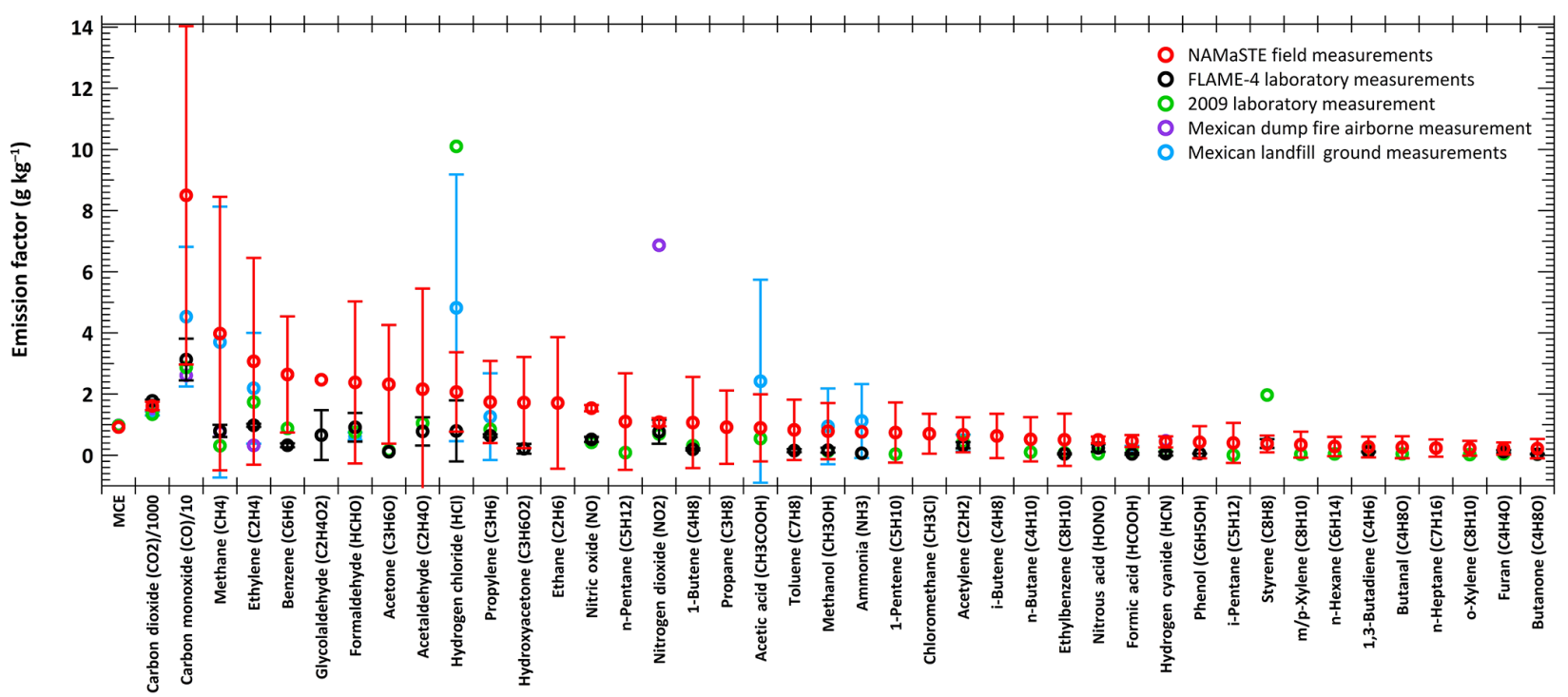

Figure 2. Garbage burning emission factors $\left(\mathrm{g} \mathrm{kg}^{-1}\right)$ compiled for laboratory measurements (Yokelson et al., 2013; Stockwell et al., 2015) (green, black), field measurements of open burning in Mexican landfills (Christian et al., 2010) (blue), a single airborne measurement from a Mexican dump fire (Yokelson et al., 2011) (purple), and our current study of mixed garbage (red). Error bars indicate 1 standard deviation of the EF for each study where available.

$\left(0.658 \mathrm{~g} \mathrm{~kg}^{-1}\right)$ for trash burning. Our 14 April fire burning "mostly plastics" in Nepal produced a very high glycolaldehyde EF $\left(4.56 \mathrm{~g} \mathrm{~kg}^{-1}\right)$. In both cases, the actual glycolaldehyde source is probably paper products, since glycolaldehyde is a product of cellulose pyrolysis (Richards, 1987). Glycolaldehyde in our first Nepal segregated plastics burn likely resulted from newspaper used as kindling for ignition. This burn also had high EFs for a few other OVOCs, especially formic and acetic acid and formaldehyde (5.30, 2.22, and $5.23 \mathrm{~g} \mathrm{~kg}^{-1}$ ). The high EFs in this study indicate that garbage burning may be an important source of these aldehydes and acids. Co-firing paper with plastics is also the likely reason our 14 April mostly plastics simulation burned at a significantly lower MCE than the pure plastic shopping bags that were burned during the FLAME-4 campaign. Most garbage is a more complex mixture than just paper and plastic, so our average EFs for garbage burning in Nepal in Table 3 are based on only the results from sampling mixed-garbage burns.

NMHCs were major emissions with ethylene and acetylene always important for both the mixed-garbage and the mostly plastic burns. Interestingly, benzene (a carcinogen) was just below ethylene as the most abundant NMHC in mixed-garbage burning emissions overall (Fig. 2). Estimates of waste burning by country for all countries are presented in Wiedinmyer et al. (2014). For Nepal, the estimated amount of waste burned is $644 \mathrm{Gg}$ per year. Based on our average benzene EF for garbage burning $\left(2.61 \pm 1.85 \mathrm{~g} \mathrm{~kg}^{-1}\right)$, we estimate that trash burning in Nepal produces $\sim 1.68 \mathrm{Gg}$ benzene (range $0.490-2.87 \mathrm{Gg}$ ) annually. The central estimate of Wiedinmyer et al. (2014) is $0.580 \mathrm{Gg} \mathrm{yr}^{-1}$ of benzene emit- ted from Nepali garbage burning; at the lower end of our range but only $34 \%$ of our mean.

As observed in Fig. 2, EF $\mathrm{HCl}$ varies significantly between experiments and within the same study. Yokelson et al. (2013) reported a lab-measured $\mathrm{EF} \mathrm{HCl}$ of $10.1 \mathrm{~g} \mathrm{~kg}^{-1}$, whereas Stockwell et al. (2014) reported their highest labmeasured $\mathrm{EF} \mathrm{HCl}$ at $1.52 \mathrm{~g} \mathrm{~kg}^{-1}$. These values are close to the upper and lower end of $\mathrm{EF} \mathrm{HCl}$ for authentic Mexican landfill fires (1.65-9.8 $\mathrm{g} \mathrm{kg}^{-1}$ ) (Christian et al., 2010). $\mathrm{HCl}$ fell below the detection limit in some FTIR grab samples collected during NAMaSTE, indicating that GB emissions can differ depending on which components are burning during a particular grab sample. Our 14 April burn with fuels that were mostly plastics had extremely high $\mathrm{EF} \mathrm{HCl}$ $\left(77.9 \mathrm{~g} \mathrm{~kg}^{-1}\right)$, suggesting that many of the bags burned were made from polyvinyl chloride (PVC). Our average EF for $\mathrm{HCl}$ for mixed $\mathrm{GB}$ was $2.32 \pm 1.01$, well within the range for Mexican GB. The other major halogenated emission detected from mixed GB was chloromethane (by WAS) at an EF up to $1.59 \mathrm{~g} \mathrm{~kg}^{-1}$ (average $0.702 \pm 0.648 \mathrm{~g} \mathrm{~kg}^{-1}$ ).

$\mathrm{HCN}$ is considered useful as a biomass burning tracer (Li et al., 2000) but was emitted by the mixed-garbage and mostly plastic burns with an EF HCN that is similar to BB. We did not collect data in Nepal for acetonitrile, which is also used as a $\mathrm{BB}$ tracer, but the high $\mathrm{CH}_{3} \mathrm{CN} / \mathrm{HCN}$ ratios in Stockwell et al. (2015) for laboratory garbage burning suggest a similar issue may occur. This should be factored into any source apportionment based on using these compounds as tracers in regions where the emission sources include BB and either or both of garbage burning and motorcycles (e.g., Sect. 3.2). 


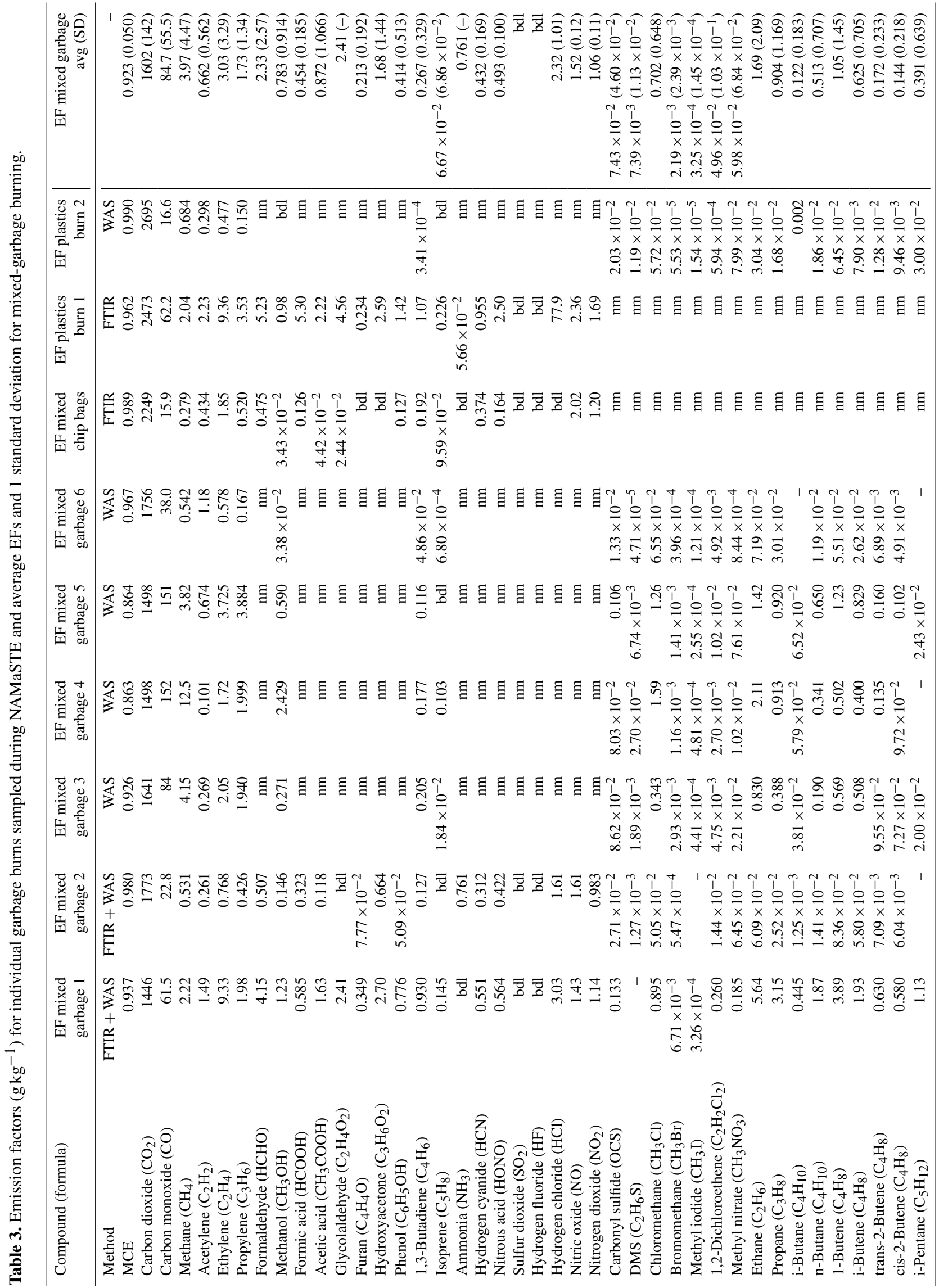




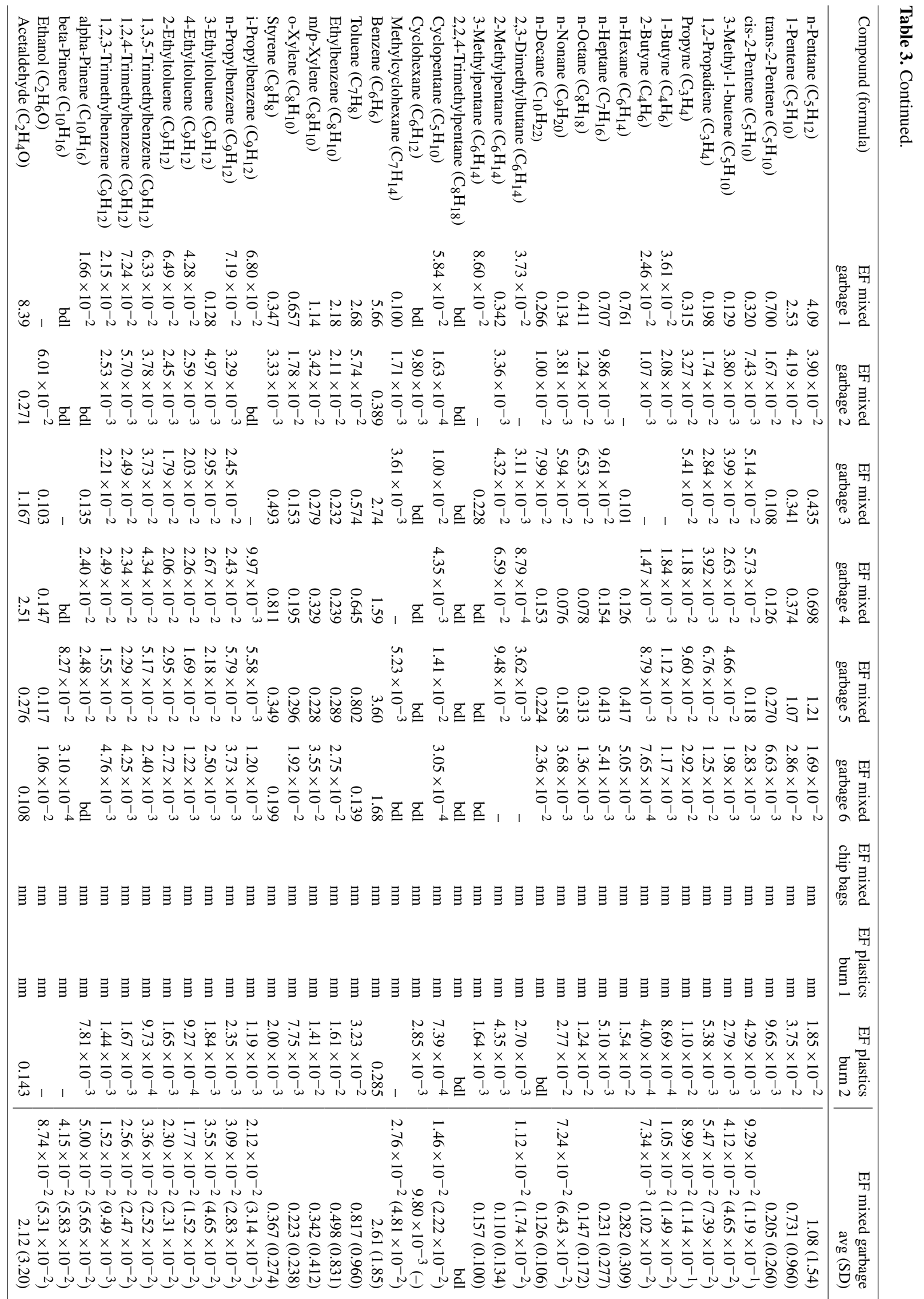




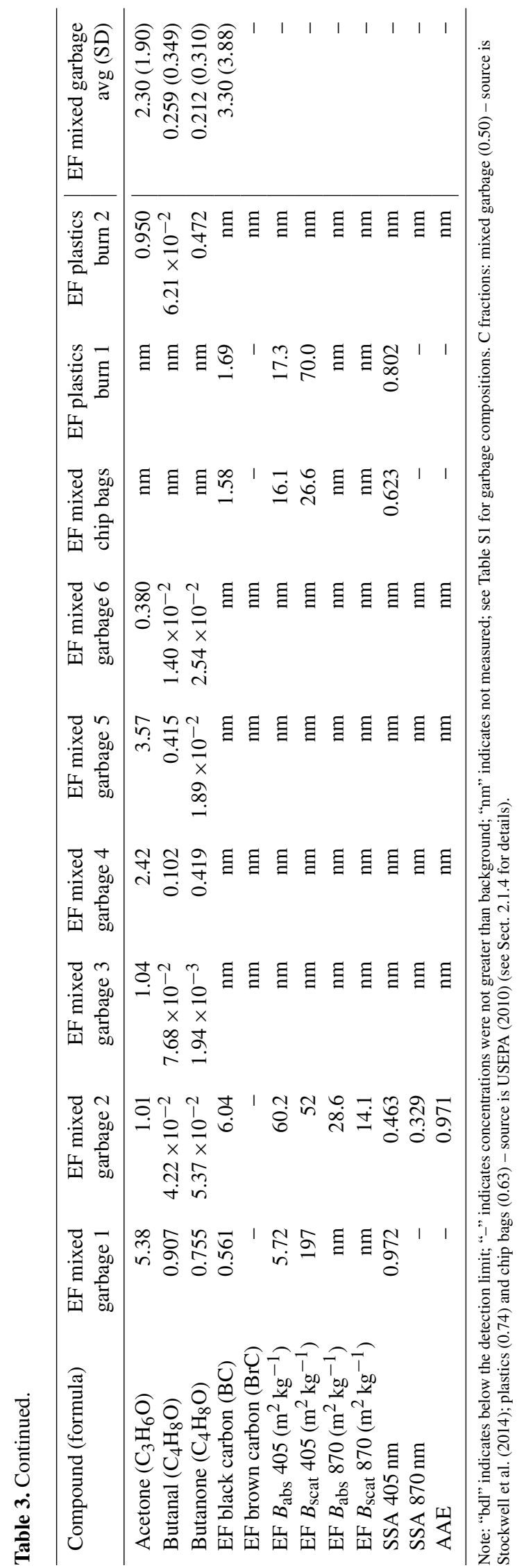

Carbonyl sulfide (OCS) is emitted by natural (oceans, volcanoes, etc.), BB, and anthropogenic (automobiles, fossil fuel combustion) sources (Kettle et al., 2002). Two of our mixed-garbage burns had high EF OCS $\left(>0.1 \mathrm{~g} \mathrm{~kg}^{-1}\right)$, and these are the first measurements reporting an EF OCS for GB. Burns 1 and 5 (Table 3) both had high OCS and both had a higher percentage of food waste. Because OCS is relatively inert in the troposphere, it freely transports into the stratosphere where it photodissociates and oxidizes and can ultimately contribute to particle mass. The other S species we could measure remained low such as dimethyl sulfide (DMS) or below detection $\left(\mathrm{SO}_{2}\right)$.

The global garbage burning inventory of Wiedinmyer et al. (2014) had to rely on the EF BC (actually a filter-based EC (elemental carbon) measurement) from just one study (0.65 $\mathrm{g} \mathrm{kg}^{-1}$, Christian et al., 2010). Both PAXs were operational during one mixed-garbage burn, and we measured an $\mathrm{EF} \mathrm{BC}$ of $6.04 \mathrm{~g} \mathrm{~kg}^{-1}$ (with an $\mathrm{AAE} \sim 1$ ) almost 10 times larger than the previously measured $\mathrm{EF}$ for $\mathrm{BC}$, suggesting a strongly $\mathrm{BC}$-dominated aerosol. In addition, we can estimate an upper limit for $\mathrm{EF} \mathrm{BC}$ for some of the other trash fires by assuming all $405 \mathrm{~nm}$ absorption is due to $\mathrm{BC}$ while the $870 \mathrm{PAX}$ was not operational. This provides our 405-estimated values in Table 3 and they range from $\sim 0.561$ to $1.69 \mathrm{~g} \mathrm{~kg}^{-1}$. Thus, our EF of $6.04 \mathrm{~g} \mathrm{~kg}^{-1}$ is likely a high-end value from a flaming-dominated garbage fire (MCE 0.980), while our lower values come from fires with more smoldering (MCE 0.96) that are probably more common. Overall our PAX data suggests an upward revision for the literature-average garbage-burning EF BC to something above $1 \mathrm{~g} \mathrm{~kg}^{-1}$. However, with only one robust PAXbased EF BC determination, we will rely on the detailed $\mathrm{EC}$ and OC (organic carbon) particulate analysis from NAMaSTE to better characterize this source in Jayarathne et al. (2016).

\subsection{Cooking-fire emissions}

There were two main goals of our cooking-fire measurements. One was to increase the amount of chemically and optically detailed trace gas and aerosol information that has been quantified in the field to allow more comprehensive assessments of the atmospheric and health impacts. The second was to obtain this type of detailed information for cooking fires that represent the most common global practice (open hardwood-fuel cooking fires); a major undersampled regional cooking practice (dung-fueled cooking fires); and, in exploratory fashion, a diverse range of stove-fuel combinations being considered as mitigation strategies.

First, we illustrate the range of cooking technologies that we sampled and support some basic observations by plotting the MCE of all the stove-fuel combinations that we tested in decreasing order in Fig. 3. Several things stand out. Firstly, the biogas, the bhuse chulo sawdust, and biobriquette-fueled stoves had the highest MCE in our (limited) testing out of the 


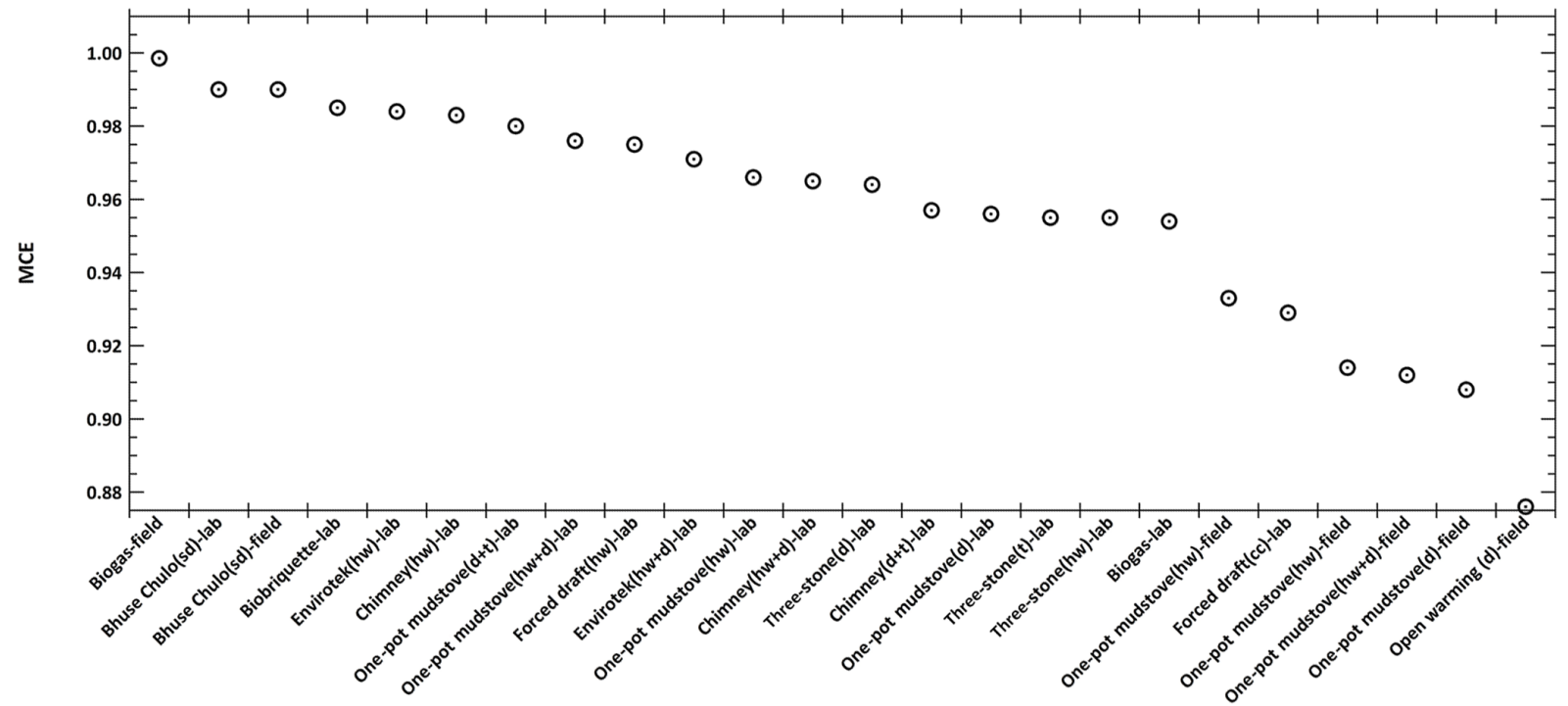

Figure 3. The modified combustion efficiency (MCE) shown in descending order for each cookstove-fuel combination measured in this study. The stove type is listed followed by the main fuel constituents and an indication whether the source was a lab or field measurement. Note: "hw" indicates hardwood fuels; "d" indicates dung; "cc" indicates charcoal; "t" indicates twigs; and "sd" indicates sawdust.

wide range of possibilities and generally had smaller gasphase EFs. The two measurements for biogas varied substantially and the differences could be a gas leak through the supply line and/or lingering BB emissions present in the laboratory room; thus, we favor the field values. Biogas has proven to be a viable alternative to traditional wood sources especially in rural Nepal, where agriculture and animal husbandry are the main sources of income (Katuwal and Bohara, 2009); however, biogas stoves remain unaffordable for poorer households. The higher MCEs in our emissions survey study suggest that more extensive testing of biogas or the bhuse chulo could be warranted. The complete individual emissions for all stoves and fuels measured during NAMaSTE are included in Supplement Table S8. Another apparent feature of Fig. 3 is the sharp drop off in MCE for the tests on the right side of the figure, which were mostly field measurements as opposed to the generally higher MCE in lab measurements. This suggests that "lower" MCE near 0.92 for wood and 0.90 for dung are apparently representative of real-world use. More field tests were planned but were not completed due to the earthquake. However, lower stove MCE in the field compared to lab testing has been reported previously (Bertschi et al., 2003; Roden et al., 2008; Stockwell et al., 2014), and the literature-average MCE for field use is close to 0.92 (Akagi et al., 2011). Thus, we are fairly confident in adjusting the lab data for open cooking to reflect lower efficiency in order to use the lab tests to augment the field data. The straightforward adjustment procedure is described next.

A frequently measured smoldering compound (e.g., $\mathrm{CO}$ or $\mathrm{CH}_{4}$ ) can be used as a reference for other smoldering compounds, and $\mathrm{CO}_{2}$ is a good reference for other flaming compounds. Similar to previous work (e.g., Yokelson et al., 2008, 2013; Stockwell et al., 2014, 2015), we obtained field representative values from the lab data by multiplying the lab ER to $\mathrm{CH}_{4}$ (measured by FTIR or WAS) for smoldering compounds and the lab ER to $\mathrm{CO}_{2}$ (measured by FTIR or WAS) for flaming compounds by the field EF for $\mathrm{CH}_{4}$ and $\mathrm{CO}_{2}$, respectively. Our full original NAMaSTE data are in Table S8, and the adjusted laboratory data for gases for traditional open hardwood and dung cooking fires were averaged together with our authentic field values to estimate our NAMaSTE-average EF for open wood and dung cooking fires. Those estimates along with values from a few other studies that reported a reasonably large number of EFs for cooking fires burning wood and dung are shown in Table 4 and form the basis for much of the ensuing discussion.

We focus next on dung cooking fires, which are prevalent in South Asia. To our knowledge, there are very few studies that report any EFs for dung burning (Akagi et al., 2011), and this work significantly expands the gas-phase emissions data. The NAMaSTE-derived dung cooking-fire average in Table 4 includes four traditional dung cooking fires (one-pot mud stoves and three-stone) and an open fire intended to represent an authentic open warming fire outside a rural home. The open warming fire had a lower MCE (0.876) than our two field dung cooking fires $(0.910 \pm 0.003)$ that was slightly closer to the low MCE (0.839) average value reported in Akagi et al. (2011) based on open pasture burning of dung in Brazil (Christian et al., 2007) and laboratory burns of Indian dung (Keene et al., 2006). 
Table 4. Compiled emission factors $\left(\mathrm{g} \mathrm{kg}^{-1}\right)$ and 1 standard deviation for open traditional cooking fires using dung and wood fuels. The NAMaSTE values include field measurements and adjusted laboratory measurements.

\begin{tabular}{|c|c|c|c|c|c|}
\hline Compound (formula) & $\begin{array}{r}\text { EF hardwood cooking } \\
\text { NAMaSTE avg } \\
(\mathrm{SD})^{\mathrm{a}}\end{array}$ & $\begin{array}{r}\text { EF dung cooking } \\
\text { NAMaSTE avg } \\
(\mathrm{SD})\end{array}$ & $\begin{array}{r}\text { EF wood open cooking } \\
\text { Akagi et al. (2011) } \\
\text { avg (SD) }\end{array}$ & $\begin{array}{r}\text { EF wood open cooking } \\
\text { Stockwell et al. }(2015) \\
\text { avg }(\mathrm{SD})^{\mathrm{b}}\end{array}$ & $\begin{array}{r}\text { EF dung burning } \\
\text { Akagi et al. (2011) } \\
\text { avg (SD) }\end{array}$ \\
\hline MCE & 0.923 & 0.898 & 0.927 & 0.927 & 0.839 \\
\hline PM & - & - & $6.73(1.61)$ & - & 22.9 \\
\hline Carbon dioxide $\left(\mathrm{CO}_{2}\right)$ & $1462(16)$ & $1129(80)$ & $1548(125)$ & $1548(125)$ & $859(15)$ \\
\hline Carbon monoxide (CO) & $77.2(13.5)$ & $80.9(13.8)$ & $77.4(26.2)$ & $77.4(26)$ & $105(10)$ \\
\hline Methane $\left(\mathrm{CH}_{4}\right)$ & $5.16(1.39)$ & $6.65(0.46)$ & $4.86(2.73)$ & $4.86(0.20)$ & $11.0(3.3)$ \\
\hline Acetylene $\left(\mathrm{C}_{2} \mathrm{H}_{2}\right)$ & $0.764(0.363)$ & $0.593(0.443)$ & $0.970(0.503)$ & $0.602(0.361)$ & $\mathrm{nm}$ \\
\hline Ethylene $\left(\mathrm{C}_{2} \mathrm{H}_{4}\right)$ & $2.70(1.17)$ & $4.23(1.39)$ & $1.53(0.66)$ & $2.21(1.40)$ & $1.12(0.23)$ \\
\hline Propylene $\left(\mathrm{C}_{3} \mathrm{H}_{6}\right)$ & $0.576(0.195)$ & $1.47(0.58)$ & $0.565(0.338)$ & $0.317(0.145)$ & $1.89(0.42)$ \\
\hline Formaldehyde (HCHO) & $1.94(0.75)$ & $2.42(1.40)$ & $2.08(0.86)$ & $1.70(0.74)$ & $\mathrm{nm}$ \\
\hline Methanol $\left(\mathrm{CH}_{3} \mathrm{OH}\right)$ & $1.92(0.61)$ & $2.38(0.90)$ & $2.26(1.27)$ & $2.05(1.63)$ & $4.14(0.88)$ \\
\hline Formic acid ( $\mathrm{HCOOH})$ & $0.179(0.071)$ & $0.341(0.308)$ & $0.220(0.168)$ & $0.620(0.533)$ & $0.460(0.308)$ \\
\hline Acetic acid $\left(\mathrm{CH}_{3} \mathrm{COOH}\right)$ & $3.14(1.11)$ & $7.32(6.59)$ & $4.97(3.32)$ & $8.90(9.27)$ & $11.7(5.1)$ \\
\hline Glycolaldehyde $\left(\mathrm{C}_{2} \mathrm{H}_{4} \mathrm{O}_{2}\right)$ & $0.238(0.155)$ & $0.499(0.260)$ & $1.42(-)$ & $0.455(0.149)$ & $\mathrm{nm}$ \\
\hline Furan $\left(\mathrm{C}_{4} \mathrm{H}_{4} \mathrm{O}\right)$ & $0.241(0.024)$ & $0.534(0.209)$ & $0.400(-)$ & $0.228(0.162)$ & $0.950(0.220)$ \\
\hline Hydroxyacetone $\left(\mathrm{C}_{3} \mathrm{H}_{6} \mathrm{O}_{2}\right)$ & $1.26(0.09)$ & $3.19(2.24)$ & $\mathrm{nm}$ & $0.480(0.367)$ & $9.60(2.38)$ \\
\hline Phenol $\left(\mathrm{C}_{6} \mathrm{H}_{5} \mathrm{OH}\right)$ & $0.496(0.159)$ & $1.008(0.348)$ & $3.32(-)$ & $0.264(0.085)$ & $2.16(0.36)$ \\
\hline 1,3-Butadiene $\left(\mathrm{C}_{4} \mathrm{H}_{6}\right)$ & $0.204(0.144)$ & $0.409(0.306)$ & $\mathrm{nm}$ & $3.37 \times 10^{-2}\left(9.67 \times 10^{-3}\right)$ & $\mathrm{nm}$ \\
\hline Isoprene $\left(\mathrm{C}_{5} \mathrm{H}_{8}\right)$ & $4.16 \times 10^{-2}\left(2.23 \times 10^{-2}\right)$ & $0.325(0.443)$ & $\mathrm{nm}$ & $0.145(0.077)$ & $\mathrm{nm}$ \\
\hline Ammonia $\left(\mathrm{NH}_{3}\right)$ & $0.259(0.253)$ & $3.00(1.33)$ & $0.865(0.404)$ & $7.88 \times 10^{-2}\left(6.90 \times 10^{-2}\right)$ & $4.75(1.00)$ \\
\hline Hydrogen cyanide (HCN) & $0.557(0.247)$ & $2.01(1.25)$ & $\mathrm{nm}$ & $0.221(0.005)$ & $0.530(0.300)$ \\
\hline Nitrous acid (HONO) & $0.452(0.068)$ & $0.276(0.101)$ & $\mathrm{nm}$ & $0.291(0.169)$ & $\mathrm{nm}$ \\
\hline Sulfur dioxide $\left(\mathrm{SO}_{2}\right)$ & bdl & bdl & $\mathrm{nm}$ & 0.499 & $6.00 \times 10^{-2}(-)$ \\
\hline Hydrogen fluoride (HF) & bdl & bdl & $\mathrm{nm}$ & bdl & $\mathrm{nm}$ \\
\hline Hydrogen chloride $(\mathrm{HCl})$ & $7.51 \times 10^{-2}\left(7.99 \times 10^{-2}\right)$ & $3.76 \times 10^{-2}\left(3.59 \times 10^{-2}\right)$ & $\mathrm{nm}$ & bdl & $\mathrm{nm}$ \\
\hline Nitric oxide $(\mathrm{NO})$ & $1.62(1.30)$ & $2.22(1.02)$ & $1.72(0.75)$ & $0.319(0.089)$ & 0.500 \\
\hline Nitrogen dioxide $\left(\mathrm{NO}_{2}\right)$ & $0.577(0.348)$ & $0.898(0.444)$ & $0.490(0.330)$ & $1.11(0.28)$ & $\mathrm{nm}$ \\
\hline Carbonyl sulfide (OCS) & $1.87 \times 10^{-2}\left(1.15 \times 10^{-2}\right)$ & $0.148(0.123)$ & $\mathrm{nm}$ & $\mathrm{nm}$ & $\mathrm{nm}$ \\
\hline $\operatorname{DMS}\left(\mathrm{C}_{2} \mathrm{H}_{6} \mathrm{~S}\right)$ & $0.255(0.359)$ & $2.37 \times 10^{-2}\left(7.67 \times 10^{-4}\right)$ & $\mathrm{nm}$ & $\mathrm{nm}$ & $\mathrm{nm}$ \\
\hline Chloromethane $\left(\mathrm{CH}_{3} \mathrm{Cl}\right)$ & $2.36 \times 10^{-2}\left(1.62 \times 10^{-2}\right)$ & $1.60(1.53)$ & $\mathrm{nm}$ & $\mathrm{nm}$ & $\mathrm{nm}$ \\
\hline Bromomethane $\left(\mathrm{CH}_{3} \mathrm{Br}\right)$ & $5.61 \times 10^{-4}\left(3.01 \times 10^{-4}\right)$ & $5.34 \times 10^{-3}\left(3.02 \times 10^{-3}\right)$ & $\mathrm{nm}$ & $\mathrm{nm}$ & $\mathrm{nm}$ \\
\hline Methyl iodide $\left(\mathrm{CH}_{3} \mathrm{I}\right)$ & $1.23 \times 10^{-4}\left(1.11 \times 10^{-4}\right)$ & $4.39 \times 10^{-4}\left(1.78 \times 10^{-4}\right)$ & $\mathrm{nm}$ & $\mathrm{nm}$ & $\mathrm{nm}$ \\
\hline 1,2-Dichloroethene $\left(\mathrm{C}_{2} \mathrm{H}_{2} \mathrm{Cl}_{2}\right)$ & $1.24 \times 10^{-4}(3.00 \mathrm{E}-5)$ & $4.97 \times 10^{-3}(-)$ & $\mathrm{nm}$ & $\mathrm{nm}$ & $\mathrm{nm}$ \\
\hline Methyl nitrate $\left(\mathrm{CH}_{3} \mathrm{NO}_{3}\right)$ & $6.96 \times 10^{-3}\left(5.73 \times 10^{-3}\right)$ & $1.46 \times 10^{-2}\left(1.94 \times 10^{-2}\right)$ & $\mathrm{nm}$ & $\mathrm{nm}$ & $\mathrm{nm}$ \\
\hline Ethane $\left(\mathrm{C}_{2} \mathrm{H}_{6}\right)$ & $0.160(0.122)$ & $1.075(0.300)$ & $1.50(0.50)$ & $\mathrm{nm}$ & $\mathrm{nm}$ \\
\hline Propane $\left(\mathrm{C}_{3} \mathrm{H}_{8}\right)$ & $0.202(0.140)$ & $0.457(0.137)$ & $\mathrm{nm}$ & $\mathrm{nm}$ & $\mathrm{nm}$ \\
\hline i-Butane $\left(\mathrm{C}_{4} \mathrm{H}_{10}\right)$ & $0.406(0.478)$ & $0.215(0.126)$ & $\mathrm{nm}$ & $\mathrm{nm}$ & $\mathrm{nm}$ \\
\hline n-Butane $\left(\mathrm{C}_{4} \mathrm{H}_{10}\right)$ & $1.11(1.48)$ & $0.29(0.09)$ & $\mathrm{nm}$ & $\mathrm{nm}$ & $\mathrm{nm}$ \\
\hline 1-Butene $\left(\mathrm{C}_{4} \mathrm{H}_{8}\right)$ & $0.726(0.904)$ & $0.399(0.331)$ & $\mathrm{nm}$ & $0.245(0.148)$ & $\mathrm{nm}$ \\
\hline i-Butene $\left(\mathrm{C}_{4} \mathrm{H}_{8}\right)$ & $0.846(1.113)$ & $0.281(0.091)$ & $\mathrm{nm}$ & $\mathrm{nm}$ & $\mathrm{nm}$ \\
\hline trans-2-Butene $\left(\mathrm{C}_{4} \mathrm{H}_{8}\right)$ & $6.78 \times 10^{-2}\left(5.98 \times 10^{-2}\right)$ & $0.151(0.010)$ & $\mathrm{nm}$ & $\mathrm{nm}$ & $\mathrm{nm}$ \\
\hline cis-2-Butene $\left(\mathrm{C}_{4} \mathrm{H}_{8}\right)$ & $5.51 \times 10^{-2}\left(4.76 \times 10^{-2}\right)$ & $0.102(0.016)$ & $\mathrm{nm}$ & $\mathrm{nm}$ & $\mathrm{nm}$ \\
\hline i-Pentane $\left(\mathrm{C}_{5} \mathrm{H}_{12}\right)$ & $8.58 \times 10^{-2}\left(1.58 \times 10^{-2}\right)$ & $0.811(0.387)$ & $\mathrm{nm}$ & $\mathrm{nm}$ & $\mathrm{nm}$ \\
\hline n-Pentane $\left(\mathrm{C}_{5} \mathrm{H}_{12}\right)$ & $2.18 \times 10^{-2}\left(1.73 \times 10^{-2}\right)$ & $0.190(0.254)$ & $\mathrm{nm}$ & $\mathrm{nm}$ & $\mathrm{nm}$ \\
\hline 1-Pentene $\left(\mathrm{C}_{5} \mathrm{H}_{10}\right)$ & $1.43 \times 10^{-2}\left(9.36 \times 10^{-3}\right)$ & $0.168(0.086)$ & $\mathrm{nm}$ & $\mathrm{nm}$ & $\mathrm{nm}$ \\
\hline trans-2-Pentene $\left(\mathrm{C}_{5} \mathrm{H}_{10}\right)$ & $1.05 \times 10^{-2}\left(8.30 \times 10^{-3}\right)$ & $0.115(0.035)$ & $\mathrm{nm}$ & $\mathrm{nm}$ & $\mathrm{nm}$ \\
\hline cis-2-Pentene $\left(\mathrm{C}_{5} \mathrm{H}_{10}\right)$ & $8.69 \times 10^{-3}(-)$ & $5.14 \times 10^{-2}\left(7.55 \times 10^{-3}\right)$ & $\mathrm{nm}$ & $\mathrm{nm}$ & $\mathrm{nm}$ \\
\hline 3-Methyl-1-butene $\left(\mathrm{C}_{5} \mathrm{H}_{10}\right)$ & $7.43 \times 10^{-3}\left(5.79 \times 10^{-3}\right)$ & $5.58 \times 10^{-2}\left(3.50 \times 10^{-2}\right)$ & $\mathrm{nm}$ & $\mathrm{nm}$ & $\mathrm{nm}$ \\
\hline 1,2-Propadiene $\left(\mathrm{C}_{3} \mathrm{H}_{4}\right)$ & $2.33 \times 10^{-2}\left(1.07 \times 10^{-2}\right)$ & $7.15 \times 10^{-2}\left(6.76 \times 10^{-2}\right)$ & $\mathrm{nm}$ & $\mathrm{nm}$ & $\mathrm{nm}$ \\
\hline Propyne $\left(\mathrm{C}_{3} \mathrm{H}_{4}\right)$ & $6.39 \times 10^{-2}\left(3.07 \times 10^{-2}\right)$ & $0.172(0.156)$ & $\mathrm{nm}$ & $\mathrm{nm}$ & $\mathrm{nm}$ \\
\hline 1-Butyne $\left(\mathrm{C}_{4} \mathrm{H}_{6}\right)$ & $1.28 \times 10^{-2}\left(4.73 \times 10^{-3}\right)$ & $2.29 \times 10^{-2}\left(1.38 \times 10^{-2}\right)$ & $\mathrm{nm}$ & $\mathrm{nm}$ & $\mathrm{nm}$ \\
\hline 2-Butyne $\left(\mathrm{C}_{4} \mathrm{H}_{6}\right)$ & $1.02 \times 10^{-2}\left(6.56 \times 10^{-3}\right)$ & $1.86 \times 10^{-2}\left(9.11 \times 10^{-3}\right)$ & $\mathrm{nm}$ & $\mathrm{nm}$ & $\mathrm{nm}$ \\
\hline n-Hexane $\left(\mathrm{C}_{6} \mathrm{H}_{14}\right)$ & $1.85 \times 10^{-2}(-)$ & $0.291(0.248)$ & $\mathrm{nm}$ & $\mathrm{nm}$ & $\mathrm{nm}$ \\
\hline n-Heptane $\left(\mathrm{C}_{7} \mathrm{H}_{16}\right)$ & $1.01 \times 10^{-2}\left(1.35 \times 10^{-2}\right)$ & $0.114(0.069)$ & $\mathrm{nm}$ & $\mathrm{nm}$ & $\mathrm{nm}$ \\
\hline n-Octane $\left(\mathrm{C}_{8} \mathrm{H}_{18}\right)$ & $1.75 \times 10^{-2}(-)$ & $4.77 \times 10^{-2}\left(9.85 \times 10^{-3}\right)$ & $\mathrm{nm}$ & $\mathrm{nm}$ & $\mathrm{nm}$ \\
\hline n-Nonane $\left(\mathrm{C}_{9} \mathrm{H}_{20}\right)$ & $4.87 \times 10^{-2}\left(6.40 \times 10^{-2}\right)$ & $4.68 \times 10^{-2}\left(2.55 \times 10^{-2}\right)$ & $\mathrm{nm}$ & $\mathrm{nm}$ & $\mathrm{nm}$ \\
\hline n-Decane $\left(\mathrm{C}_{10} \mathrm{H}_{22}\right)$ & $6.90 \times 10^{-2}\left(9.61 \times 10^{-2}\right)$ & $4.71 \times 10^{-2}\left(4.03 \times 10^{-2}\right)$ & $\mathrm{nm}$ & $\mathrm{nm}$ & $\mathrm{nm}$ \\
\hline 2,3-Dimethylbutane $\left(\mathrm{C}_{6} \mathrm{H}_{14}\right)$ & $1.57 \times 10^{-2}\left(1.16 \times 10^{-2}\right)$ & $0.112(0.105)$ & $\mathrm{nm}$ & $\mathrm{nm}$ & $\mathrm{nm}$ \\
\hline 2-Methylpentane $\left(\mathrm{C}_{6} \mathrm{H}_{14}\right)$ & $9.93 \times 10^{-3}\left(1.29 \times 10^{-2}\right)$ & $0.231(0.192)$ & $\mathrm{nm}$ & $\mathrm{nm}$ & $\mathrm{nm}$ \\
\hline 3-Methylpentane $\left(\mathrm{C}_{6} \mathrm{H}_{14}\right)$ & $6.79 \times 10^{-3}\left(6.63 \times 10^{-3}\right)$ & $0.155(0.137)$ & $\mathrm{nm}$ & $\mathrm{nm}$ & $\mathrm{nm}$ \\
\hline 2,2,4-Trimethylpentane $\left(\mathrm{C}_{8} \mathrm{H}_{18}\right)$ & $-(-)$ & $0.100(0.080)$ & $\mathrm{nm}$ & $\mathrm{nm}$ & $\mathrm{nm}$ \\
\hline Cyclopentane $\left(\mathrm{C}_{5} \mathrm{H}_{10}\right)$ & $4.06 \times 10^{-3}(-)$ & $0.146(0.178)$ & $\mathrm{nm}$ & $\mathrm{nm}$ & $\mathrm{nm}$ \\
\hline Cyclohexane $\left(\mathrm{C}_{6} \mathrm{H}_{12}\right)$ & $1.16 \times 10^{-2}(-)$ & $0.224(0.255)$ & $\mathrm{nm}$ & $\mathrm{nm}$ & $\mathrm{nm}$ \\
\hline Methylcyclohexane $\left(\mathrm{C}_{7} \mathrm{H}_{14}\right)$ & $1.62 \times 10^{-2}(-)$ & $4.76 \times 10^{-2}\left(3.96 \times 10^{-2}\right)$ & $\mathrm{nm}$ & $\mathrm{nm}$ & $\mathrm{nm}$ \\
\hline Benzene $\left(\mathrm{C}_{6} \mathrm{H}_{6}\right)$ & $1.05(0.19)$ & $1.96(0.45)$ & $\mathrm{nm}$ & $2.58(2.68)$ & $\mathrm{nm}$ \\
\hline Toluene $\left(\mathrm{C}_{7} \mathrm{H}_{8}\right)$ & $0.241(0.160)$ & $1.26(0.05)$ & $\mathrm{nm}$ & $0.290(0.311)$ & $\mathrm{nm}$ \\
\hline Ethylbenzene $\left(\mathrm{C}_{8} \mathrm{H}_{10}\right)$ & $4.19 \times 10^{-2}\left(4.25 \times 10^{-2}\right)$ & $0.366(0.085)$ & $\mathrm{nm}$ & $\mathrm{nm}$ & $\mathrm{nm}$ \\
\hline
\end{tabular}


Table 4. Continued.

\begin{tabular}{|c|c|c|c|c|c|}
\hline Compound (formula) & $\begin{array}{r}\text { EF hardwood cooking } \\
\text { NAMaSTE avg } \\
(\mathrm{SD})^{\mathrm{a}}\end{array}$ & $\begin{array}{r}\text { EF dung cooking } \\
\text { NAMaSTE avg } \\
(\mathrm{SD})\end{array}$ & $\begin{array}{r}\text { EF wood open cooking } \\
\text { Akagi et al. (2011) } \\
\text { avg (SD) }\end{array}$ & $\begin{array}{r}\text { EF wood open cooking } \\
\text { Stockwell et al. (2015) } \\
\text { avg (SD) }\end{array}$ & $\begin{array}{r}\text { EF dung burning } \\
\text { Akagi et al. (2011) } \\
\text { avg (SD) }\end{array}$ \\
\hline $\mathrm{m} / \mathrm{p}$-Xylene $\left(\mathrm{C}_{8} \mathrm{H}_{10}\right)$ & $9.57 \times 10^{-2}\left(7.99 \times 10^{-2}\right)$ & $0.601(0.294)$ & $\mathrm{nm}$ & $0.265(0.380)$ & $\mathrm{nm}$ \\
\hline o-Xylene $\left(\mathrm{C}_{8} \mathrm{H}_{10}\right)$ & $3.93 \times 10^{-2}\left(4.31 \times 10^{-2}\right)$ & $0.228(0.083)$ & $\mathrm{nm}$ & $\mathrm{nm}$ & $\mathrm{nm}$ \\
\hline Styrene $\left(\mathrm{C}_{8} \mathrm{H}_{8}\right)$ & $8.71 \times 10^{-2}\left(6.69 \times 10^{-2}\right)$ & $0.255(0.091)$ & $\mathrm{nm}$ & $0.234(0.306)$ & $\mathrm{nm}$ \\
\hline i-Propylbenzene $\left(\mathrm{C}_{9} \mathrm{H}_{12}\right)$ & $1.70 \times 10^{-2}\left(1.67 \times 10^{-2}\right)$ & $1.87 \times 10^{-2}\left(1.40 \times 10^{-2}\right)$ & $\mathrm{nm}$ & $\mathrm{nm}$ & $\mathrm{nm}$ \\
\hline n-Propylbenzene $\left(\mathrm{C}_{9} \mathrm{H}_{12}\right)$ & $1.78 \times 10^{-2}\left(1.58 \times 10^{-2}\right)$ & $3.10 \times 10^{-2}\left(1.45 \times 10^{-2}\right)$ & $\mathrm{nm}$ & $\mathrm{nm}$ & $\mathrm{nm}$ \\
\hline 3-Ethyltoluene $\left(\mathrm{C}_{9} \mathrm{H}_{12}\right)$ & $2.62 \times 10^{-2}\left(5.41 \times 10^{-3}\right)$ & $5.61 \times 10^{-2}\left(2.38 \times 10^{-2}\right)$ & $\mathrm{nm}$ & $\mathrm{nm}$ & $\mathrm{nm}$ \\
\hline 4-Ethyltoluene $\left(\mathrm{C}_{9} \mathrm{H}_{12}\right)$ & $2.07 \times 10^{-2}\left(1.19 \times 10^{-2}\right)$ & $3.57 \times 10^{-2}\left(1.74 \times 10^{-2}\right)$ & $\mathrm{nm}$ & $\mathrm{nm}$ & $\mathrm{nm}$ \\
\hline 2-Ethyltoluene $\left(\mathrm{C}_{9} \mathrm{H}_{12}\right)$ & $2.10 \times 10^{-2}\left(1.16 \times 10^{-2}\right)$ & $3.39 \times 10^{-2}\left(1.34 \times 10^{-2}\right)$ & $\mathrm{nm}$ & $\mathrm{nm}$ & $\mathrm{nm}$ \\
\hline 1,3,5-Trimethylbenzene $\left(\mathrm{C}_{9} \mathrm{H}_{12}\right)$ & $2.14 \times 10^{-2}(-)$ & $1.79 \times 10^{-2}\left(8.32 \times 10^{-3}\right)$ & $\mathrm{nm}$ & $7.01 \times 10^{-2}\left(9.27 \times 10^{-2}\right)$ & $\mathrm{nm}$ \\
\hline $1,2,4$-Trimethylbenzene $\left(\mathrm{C}_{9} \mathrm{H}_{12}\right)$ & $1.74 \times 10^{-2}\left(2.35 \times 10^{-2}\right)$ & $3.91 \times 10^{-2}\left(1.65 \times 10^{-2}\right)$ & $\mathrm{nm}$ & $\mathrm{nm}$ & $\mathrm{nm}$ \\
\hline 1,2,3-Trimethylbenzene $\left(\mathrm{C}_{9} \mathrm{H}_{12}\right)$ & $2.16 \times 10^{-2}(-)$ & $2.34 \times 10^{-2}\left(4.30 \times 10^{-3}\right)$ & $\mathrm{nm}$ & $\mathrm{nm}$ & $\mathrm{nm}$ \\
\hline alpha-Pinene $\left(\mathrm{C}_{10} \mathrm{H}_{16}\right)$ & $2.02 \times 10^{-2}\left(2.33 \times 10^{-2}\right)$ & $0.348(0.487)^{\mathrm{c}}$ & $\mathrm{nm}$ & $0.197(0.257)$ & $\mathrm{nm}$ \\
\hline beta-Pinene $\left(\mathrm{C}_{10} \mathrm{H}_{16}\right)$ & $4.67 \times 10^{-2}(-)$ & $0.471(-)^{\mathrm{c}}$ & $\mathrm{nm}$ & $\mathrm{nm}$ & $\mathrm{nm}$ \\
\hline Ethanol $\left(\mathrm{C}_{2} \mathrm{H}_{6} \mathrm{O}\right)$ & $0.128(0.017)$ & $0.563(0.589)$ & $\mathrm{nm}$ & $\mathrm{nm}$ & $\mathrm{nm}$ \\
\hline Acetaldehyde $\left(\mathrm{C}_{2} \mathrm{H}_{4} \mathrm{O}\right)$ & $0.541(0.362)$ & $1.88(1.63)$ & $\mathrm{nm}$ & $0.792(0.439)$ & $\mathrm{nm}$ \\
\hline Acetone $\left(\mathrm{C}_{3} \mathrm{H}_{6} \mathrm{O}\right)$ & $0.524(0.256)$ & $1.63(0.38)$ & $\mathrm{nm}$ & $\mathrm{nm}$ & $\mathrm{nm}$ \\
\hline Butanal $\left(\mathrm{C}_{4} \mathrm{H}_{8} \mathrm{O}\right)$ & $8.28 \times 10^{-3}\left(6.27 \times 10^{-3}\right)$ & $5.40 \times 10^{-2}\left(2.19 \times 10^{-2}\right)$ & $\mathrm{nm}$ & $\mathrm{nm}$ & $\mathrm{nm}$ \\
\hline Butanone $\left(\mathrm{C}_{4} \mathrm{H}_{8} \mathrm{O}\right)$ & $0.232(0.286)$ & $0.262(0.109)$ & $\mathrm{nm}$ & $8.04 \times 10^{-2}\left(4.98 \times 10^{-2}\right)$ & $\mathrm{nm}$ \\
\hline EF black carbon (BC) & $0.221(0.127)$ & $4.15 \times 10^{-2}\left(3.18 \times 10^{-2}\right)$ & $0.833(0.453)$ & $\mathrm{nm}$ & $\mathrm{nm}$ \\
\hline EF brown carbon $(\mathrm{BrC})$ & $8.59(5.62)$ & $5.54(1.66)$ & $\mathrm{nm}$ & $\mathrm{nm}$ & $\mathrm{nm}$ \\
\hline $\mathrm{EF} B_{\mathrm{abs}} 405\left(\mathrm{~m}^{2} \mathrm{~kg}^{-1}\right)$ & $10.6(6.8)$ & $5.85(1.95)$ & $\mathrm{nm}$ & $\mathrm{nm}$ & $\mathrm{nm}$ \\
\hline EF $B_{\text {scat }} 405\left(\mathrm{~m}^{2} \mathrm{~kg}^{-1}\right)$ & $40.4(23.8)$ & $49.5(5.8)$ & $\mathrm{nm}$ & $\mathrm{nm}$ & $\mathrm{nm}$ \\
\hline $\mathrm{EF} B_{\mathrm{abs}} 870\left(\mathrm{~m}^{2} \mathrm{~kg}^{-1}\right)$ & $1.04(0.60)$ & $0.197(0.151)$ & $\mathrm{nm}$ & $\mathrm{nm}$ & $\mathrm{nm}$ \\
\hline EF $B_{\text {scat }} 870\left(\mathrm{~m}^{2} \mathrm{~kg}^{-1}\right)$ & $1.51(0.52)$ & $0.922(0.324)$ & $\mathrm{nm}$ & $\mathrm{nm}$ & $\mathrm{nm}$ \\
\hline $\mathrm{EF} B_{\mathrm{abs}} 405$ just $\mathrm{BrC}\left(\mathrm{m}^{2} \mathrm{~kg}^{-1}\right)$ & $8.40(5.48)$ & $5.43(1.62)$ & $\mathrm{nm}$ & $\mathrm{nm}$ & $\mathrm{nm}$ \\
\hline $\mathrm{EF} B_{\text {abs }} 405$ just $\mathrm{BC}\left(\mathrm{m}^{2} \mathrm{~kg}^{-1}\right)$ & $2.24(1.28)$ & $0.423(0.324)$ & $\mathrm{nm}$ & $\mathrm{nm}$ & $\mathrm{nm}$ \\
\hline SSA $405 \mathrm{~nm}$ & $0.605(0.061)$ & $0.811(0.164)$ & $\mathrm{nm}$ & $\mathrm{nm}$ & $\mathrm{nm}$ \\
\hline SSA $870 \mathrm{~nm}$ & $0.794(0.009)$ & $0.893(0.043)$ & $\mathrm{nm}$ & $\mathrm{nm}$ & $\mathrm{nm}$ \\
\hline AAE & $3.01(0.10)$ & $4.63(0.68)$ & $\mathrm{nm}$ & $\mathrm{nm}$ & $\mathrm{nm}$ \\
\hline
\end{tabular}

values. Aerosol values include field measurements only (see Sect. 3.6). ${ }^{\mathrm{b}}$ This includes laboratory adjusted values (see Stockwell et al., 2014, 2015); additional gas-phase compounds are reported therein. ${ }^{\mathrm{c}}$ High monoterpene values likely due to wood kindling.

As shown for dung-fuel cooking fires in Table 4, our EFs for $\mathrm{CH}_{4}\left(6.65 \pm 0.46 \mathrm{~g} \mathrm{~kg}^{-1}\right)$ are lower than the literature average reported in Akagi et al. (2011) $\left(11 \mathrm{~g} \mathrm{~kg}^{-1}\right)$, although both are within the range $\left(3-18 \mathrm{~g} \mathrm{~kg}^{-1}\right)$ reported by Smith et al. (2000) for simulated rural cooking in India. OVOCs were major emissions, and we provide the first EFs for many OVOCs (e.g., formaldehyde, acetone, glycolaldehyde, acetaldehyde). Acetic acid and hydroxyacetone were the most abundant OVOCs, though the Nepal EFs (7.32 and $3.19 \mathrm{~g} \mathrm{~kg}^{-1}$ ) are lower than the Brazil EFs (14.3 and $9.6 \mathrm{~g} \mathrm{~kg}^{-1}$ ) reported by Christian et al. (2007) at a lower MCE. This work considerably expands our knowledge of NMHCs from this source and reports a much higher EF for $\mathrm{C}_{2} \mathrm{H}_{4}\left(4.23 \mathrm{~g} \mathrm{~kg}^{-1}\right)$ and also many previously unobserved NMHCs at high levels. In particular, our new NMHC data include high emissions for BTEX compounds, especially benzene and toluene $\left(1.96,1.26 \mathrm{~g} \mathrm{~kg}^{-1}\right)$. Other notable compounds with high emissions that were previously unobserved include chloromethane $\left(1.60 \mathrm{~g} \mathrm{~kg}^{-1}\right)$ and carbonyl sulfide $\left(0.148 \mathrm{~g} \mathrm{~kg}^{-1}\right)$. This is consistent with the elevated $\mathrm{Cl}$ and $\mathrm{S}$ content in the dung sample from Montana $(0.19 \% \mathrm{~S}$, $0.05 \% \mathrm{Cl}$; Table S3). Chloromethane is the main form of organic chlorine in the atmosphere (Lobert et al., 1999) and is discussed more below.
As expected, the high $\mathrm{N}$ content of dung (1.9\%, Table S3) led to high emissions for $\mathrm{N}$-containing gases including $\mathrm{NH}_{3}$ $\left(3 \mathrm{~g} \mathrm{~kg}^{-1}\right), \mathrm{NO}_{x}\left(\sim 3 \mathrm{~g} \mathrm{~kg}^{-1}\right)$, and $\mathrm{HCN}\left(\sim 2 \mathrm{~g} \mathrm{~kg}^{-1}\right)$. Our $\mathrm{NO}_{x} \mathrm{EF}$ is higher than previously reported and this is an EPA-regulated criteria pollutant that is an important precursor to ozone, acid rain, and nitrate aerosols. The high $\mathrm{NH}_{3}$ $\left(3.00 \pm 1.33 \mathrm{~g} \mathrm{~kg}^{-1}\right)$ and acetic acid $\left(7.32 \pm 6.59 \mathrm{~g} \mathrm{~kg}^{-1}\right)$ emissions we observed, also previously observed in Brazil dung-fire emissions, might lead to ammonium acetate in secondary aerosol. Laboratory measurements during FLAME-4 were the first to report $\mathrm{HCN}$ from wood cooking fires (Stockwell et al., 2014), though the ERs to CO were about 5 times lower than what is typically observed for other BB fuels. The NAMaSTE real-world wood cooking fires had higher $\mathrm{HCN}$ EFs $\left(0.557 \pm 0.247 \mathrm{~g} \mathrm{~kg}^{-1}\right)$ than in the lab $\left(0.221 \mathrm{~g} \mathrm{~kg}^{-1}\right)$; however, our HCN-to-CO ratio for dung burning is 3.5 times higher than for wood. Despite the lower ER for wood, its dominance as a fuel means both should be considered an important source of $\mathrm{HCN}$ in the atmosphere. The cooking source continues during the monsoon, when open burning is reduced, and likely contributes to the large HCN anomaly observed by satellite in the anticyclone over the Asian monsoon (Park et al., 2008; Randel et al., 2010; Glatthor et al., 2015). The NAMaSTE $\triangle \mathrm{HCN} / \triangle \mathrm{CO}$ ratios should be considered 
when using $\mathrm{HCN}$ in any source apportionment of pollution sources in areas subject to biomass burning and dung cooking along with the motorcycles and garbage burning mentioned above.

Yevich and Logan (2003) estimated annual Asian use of dung as a biofuel in 1985 at $123( \pm 50 \%) \mathrm{Tg}$, with India accounting for $93 \mathrm{Tg}$. The NAMaSTE field measurements of dung burning were conducted in the Tarai region, which makes up the southern part of Nepal and likely represents similar cooking conditions to those in northern India. Fernandes et al. (2007) estimated that only $75 \mathrm{Tg} \mathrm{yr}^{-1}$ of dung is burned globally, while Yevich and Logan (2003) estimated a slightly higher global value $(136 \mathrm{Tg})$. If we take the average of these two studies as an estimate of dung biofuel use $(106 \mathrm{Tg})$, then we estimate from our EFs that $0.78 \mathrm{Tg}$ acetic acid, $0.21 \mathrm{Tg} \mathrm{HCN}$, and $0.17 \mathrm{Tg} \mathrm{CH}_{3} \mathrm{Cl}$ are emitted from dung burning each year. This accounts for $\sim 33,51$, and over $100 \%$ of the previously estimated total biofuel burning emissions for these species in the late 1990s (Andreae and Merlet, 2001). Our estimate of HCN emitted solely from burning dung accounts for $\sim 4-8 \%$ of HCN thought to be emitted by total BB annually in earlier work ( $\mathrm{Li}$ et al., 2000). Our estimate of $\mathrm{CH}_{3} \mathrm{Cl}$ emitted by dung burning alone is $\sim 18 \%$ of the total global $\mathrm{CH}_{3} \mathrm{Cl}$ emitted by $\mathrm{BB}$ in the inventory of Lobert et al. (1999). They also cited a high $\mathrm{Cl}$ content of dung ( $4360 \mathrm{mg} \mathrm{kg}^{-1}$ ) and concluded that BB was the largest source of $\mathrm{CH}_{3} \mathrm{Cl}$ in the atmosphere. The contribution of dung burning to acetic acid, $\mathrm{HCN}, \mathrm{CH}_{3} \mathrm{Cl}$, and other species should be included in updated inventories of global $\mathrm{BB}$ and biofuel emissions.

We report the first $\mathrm{BrC}$ emissions data from dung burning (to our knowledge) in Table 4 based on our NAMaSTE fieldmeasured values only. Our EF BrC of $5.54 \pm 1.66 \mathrm{~g} \mathrm{~kg}^{-1}$ is qualitative but substantial, and our more rigorously measured AAE $(4.63 \pm 0.68)$ is higher than our NAMaSTE value for wood cooking (3.01 \pm 0.10$)$. Expressed in terms of light absorption, BrC accounted for $\sim 93 \%$ of aerosol absorption at $405 \mathrm{~nm}$ for dung burning and $79 \%$ for wood burning. In addition, for dung burning the BC absorption EF at $870 \mathrm{~nm}$ was only $3.5 \%$ of the "BrC-only" absorption EF at $405 \mathrm{~nm}$. Even for wood burning, the BC absorption EF at $870 \mathrm{~nm}$ was just $12 \%$ of the $\mathrm{BrC}$ absorption $\mathrm{EF}$ at $405 \mathrm{~nm}$. From these values we see that dung cooking fires are an important $\mathrm{BrC}$ source in South Asia and that BrC from cooking fires in general is of great importance for understanding their climate impacts. Our EF BC $\left(0.04 \mathrm{~g} \mathrm{~kg}^{-1}\right)$ for dung is lower than the suggested EF reported in Venkataraman et al. (2005) $\left(0.12 \mathrm{~g} \mathrm{~kg}^{-1}\right)$ for lab-burned cattle dung, though it is within the low end of the range estimated by Xiao et al. (2015) (0.03-0.3 $\left.\mathrm{g} \mathrm{kg}^{-1}\right)$ for dung cooking fires. The sum of our BC and $\mathrm{BrC}$ emissions $\left(\sim 5.5 \mathrm{~g} \mathrm{~kg}^{-1}\right)$ is significantly lower than total carbon $\left(\mathrm{EC}+\mathrm{OC}, 22 \mathrm{~g} \mathrm{~kg}^{-1}\right)$ reported for lab measurements of dung cooking fires in Keene et al. (2006), but the methods used are difficult to compare. Both studies highlight the need for more measurements of this source. The SSA for dung cooking fires is statistically higher at both wavelengths than for wood cooking, but both sources produced fresh smoke with $\mathrm{SSA}<0.9$, indicating it would (initially) warm the atmosphere and cool the surface, impacting climate (Praveen et al., 2012). Our values of EF $B_{\text {abs }}$, EF $B_{\text {scat }}$, AAE, and SSA at 405 and $870 \mathrm{~nm}$ shown in Table 4 for dung and wood burning are independent of MAC estimates and can be used in models directly to estimate the optical properties, forcing, etc.

Open cooking fires using hardwood fuel are the most common cooking technology globally. Our NAMaSTE measurements significantly increase the number of gases that have been measured in hardwood open cooking-fire emissions in the field. We report a few new OVOCs with high EF such as acetone $\left(0.524 \mathrm{~g} \mathrm{~kg}^{-1}\right)$ and many new EFs for NMHCs (Table 4). The NAMaSTE results include lower emissions of total BTEX compounds from wood cooking fires $\left(\sim 1.5 \mathrm{~g} \mathrm{~kg}^{-1}\right)$ than dung cooking fires $\left(\sim 4.5 \mathrm{~g} \mathrm{~kg}^{-1}\right)$ but confirm the high EF for these species previously reported in lab studies $\left(\sim 3.2 \mathrm{~g} \mathrm{~kg}^{-1}\right.$, Stockwell et al., 2015). DMS emissions have not been reported previously for open cooking with wood, and our EF is relatively high $\left(0.255 \mathrm{~g} \mathrm{~kg}^{-1}\right)$ for a BB source (Simpson et al., 2011). Rather than walk the reader through all the data in Table 4 , we reiterate the main result, which is that models can now use much improved speciation of the trace gases emitted by cooking fires. This can be seen by comparing columns 2 and 4 (the literature average) in Table 4 . The agreement is good for most species previously measured in the field. For example, the NAMaSTEaverage MCE (0.923) is very close to the Akagi et al. (2011) field average MCE (0.927). In addition, NAMaSTE provides data in column 2 for about 70 gases not previously measured in field work to our knowledge.

The numerous trace gas EFs we measured for openhardwood cooking fires in Nepal also present an important validation opportunity for cooking-fire trace gas measurements made on simulated cooking fires in a lab study that featured many advanced instruments mostly never deployed on field cooking fires. In FLAME-4, the lab cooking-fire EFs for trace gases were adjusted to the field average MCE (0.927) and reported in Table S3 of Stockwell et al. (2015). In Table 4 we show the overlap species between NAMaSTE and FLAME-4. There are a few noticeable deviations between the lab and NAMaSTE EF for NMOC. The lab / field EF ratios are shown in parentheses for acetic acid (2.8), hydroxyacetone (0.38), BTEX (2), and HCN (0.40). However, comparing columns 2 and 5 shows agreement within 1 standard deviation of the mean for more than $70 \%$ of the $\sim 26$ overlap species. Fuel $\mathrm{S}$ and $\mathrm{N}$ content differences may explain the EF differences for $\mathrm{SO}_{2}$ and $\mathrm{NO}_{x}$. In general the agreement suggests the FLAME-4 trace gas EF are useful, especially for the $>100$ species that the study measured that were not measured in the field (Stockwell et al., 2015; Hatch et al., 2015). The FLAME-4 and NAMaSTE data will be used to update 
the tables in Akagi et al. (2011), creating a new literature average.

As noted earlier, aerosol emissions from wood cooking fires are a major global issue. Our EF BC $\left(0.221 \pm 0.127 \mathrm{~g} \mathrm{~kg}^{-1}\right)$ for hardwood cooking fires is significantly lower than the Akagi et al. (2011) literature average $\left(0.833 \pm 0.025 \mathrm{~g} \mathrm{~kg}^{-1}\right)$ based on EC measurements but was within the range reported in Christian et al. (2010) (0.205$0.674 \mathrm{~g} \mathrm{~kg}^{-1}$ ). Our BC and $\mathrm{BrC}$ combine to $\sim 9 \mathrm{~g} \mathrm{~kg}^{-1}$, which is $\sim 40 \%$ larger than the typical value for $\mathrm{PM}_{2.5}$ from biofuel sources $\left(\sim 7 \mathrm{~g} \mathrm{~kg}^{-1}\right.$, Akagi et al., 2011). To our knowledge we report the first field-measured $\mathrm{EF} B_{\mathrm{abs}}$ and EF $B_{\text {scat }}$ for wood cooking fires at 405 and $870 \mathrm{~nm}$ (Table 4), which can be used in models without MAC assumptions. We also provide rare measurements of SSA and AAE for fresh cooking-fire aerosol in Tables 4 and S8. Our AAE for hardwood cooking fires $(3.01 \pm 0.10)$ is higher than that which Praveen et al. (2012) measured in hardwood cookingfire smoke (2.2) in the IGP in northern India. More work is required to examine how methodological differences, aging, and sample size vs. real regional variability affect measurements of regional averages. Our hardwood cooking SSAs $(0.794,870 \mathrm{~nm} ; 0.605,405 \mathrm{~nm})$ indicate an absorbing fresh aerosol, but SSA has been seen to increase rapidly with aging in BB plumes (Abel et al., 2003; Yokelson et al., 2009; Akagi et al., 2012). In summary, our PAX data from Nepal increase the total amount of sampling and approaches used to estimate regional average cooking-fire aerosol properties. Incorporating our data would nudge the regional average for hardwood cooking fires towards higher $\mathrm{BrC} / \mathrm{BC}$ ratios, and we show that dung cooking fires are also an important $\mathrm{BrC}$ source. Additional NAMaSTE aerosol data will be reported in companion papers (Jayarathne et al., 2016; Goetz et al., 2016).

Health impacts of indoor cooking-fire emissions are a major global concern (e.g., Davidson et al., 1986, and Fullerton et al., 2008). We did not target exposure assessment in NAMaSTE, but our data can be used in a piggyback approach with studies focused on longer-term exposure to a key indoor air pollutant to estimate exposure to other air toxic gases not measured in those exposure studies following Akagi et al. (2014). We give one example. Based on our measurements it is possible to extrapolate concentrations of trace species not measured in previous studies. For example, assuming similar emission profiles, we can scale indoor $\mathrm{CO}$ measured by Davidson et al. (1986) to estimate indoor benzene concentrations and exposures. In their study indoor concentrations of $\mathrm{CO}$ were $21 \mathrm{ppm}$, which would equate to $183 \mathrm{ppb}$ benzene using the ER (benzene / CO) from our study for dung cooking. The same approach can be extended to any of the gases we measured for any of the stove and fuel types. Overall, we were able to survey a very large variety of cooking technologies, practices, and fuel options representative of a diverse region and to identify candidate technologies for further testing and possible wider use. The large amount of new gas and aerosol data from NAMaSTE as a whole should improve model representation and help to better understand the local and regional climate, chemistry, and health impacts of domestic and industrial biofuel use.

\subsection{Crop residue fire emissions}

We present the first detailed measurements of trace gas chemistry and aerosol properties for burning authentic Nepali crop residues, and we also significantly expand the field emissions characterization for global agricultural residue fires. The EFs for each fire are compiled in Supplement Table S9. We examine the representativeness of our trace gas grab sampling, justify a small adjustment to the trace gas data, and then discuss the implications of the trace gas and aerosol results.

A detailed suite of EFs for several crop residues commonly burned in the US and globally that is based on continuous lab measurements over the course of whole fires is reported in Stockwell et al. (2014, 2015). A few fuels they measured overlap with our Nepal study, including wheat and rice straw. The average MCE (0.954) for our Nepal grab samples burning wheat varieties is very close to the lab-measured wheat straw burning MCE (0.956), though other crop types do not compare as well. When we compare our Nepal-average MCE for all our crop residue fire grab samples (0.952) to earlier field measurements, we find that the MCEs reported in Mexico (0.925) by Yokelson et al. (2011) and in the US (0.930) by Liu et al. (2016) are significantly lower. In addition, the previous field studies obtained more grab samples of a larger number of fires and sampled from the air, which is unlikely to return too low an MCE. The MCE that we obtained from the real-time FTIR $\mathrm{CO}$ and $\mathrm{CO}_{2}$ measurements that supported filter collection was also lower (e.g., $\sim 0.933$ ) and closer to the abovementioned field MCE values. Thus, we believe our Nepal-average MCE based on grab samples is likely biased upwards. Thus, to make our Nepal EFs more representative of the likely Nepal (and regional) average, we have adjusted it to the average airborne-measured field MCE (0.925) observed for crop residue burning in another developing country (Mexico) according to procedures similar to Stockwell et al. (2014) and also described in Sect. 3.6 above. These adjusted EFs for selected compounds are included in Table 5 along with values from selected other previous studies. Additional compounds measured in this study (both original and adjusted) are included in Supplement Table S9.

Figure 4 shows the top OVOCs, NMHCs, and S- or Ncontaining compounds emitted and shows good agreement with literature values for overlap species. As noted in Stockwell et al. (2014), glycolaldehyde (the simplest "sugar-like" molecule) is a major emission from crop residue fires and Fig. 4 shows that glycolaldehyde is the dominant NMOC by mass from the NAMaSTE crop residue fires. When we compare them to other fuel types, the EFs of glycolaldehyde from our study, smoldering Indonesian rice straw (Christian et al., 2003), and an assortment of US crop residue fuels (Stock- 
Table 5. Summary of emission factors $\left(\mathrm{g} \mathrm{kg}^{-1}\right)$ and 1 standard deviation for crop residue burns from this study and others.

\begin{tabular}{|c|c|c|c|}
\hline Compound (formula) & $\begin{array}{r}\text { EF crop residue } \\
\text { Yokelson et al. }(2011) \\
\text { avg }(\mathrm{SD})^{\mathrm{a}}\end{array}$ & $\begin{array}{r}\text { EF crop residue (food fuels) } \\
\text { Stockwell et al. (2015) } \\
\text { avg (SD) }\end{array}$ & $\begin{array}{r}\text { EF crop residue } \\
\text { NAMaSTE } \\
\text { avg }(\mathrm{SD})^{\mathrm{b}, \mathrm{c}}\end{array}$ \\
\hline MCE & 0.925 & 0.925 & 0.925 \\
\hline Carbon dioxide $\left(\mathrm{CO}_{2}\right)$ & $1398(55)$ & $1353(80)$ & $1401(68)$ \\
\hline Carbon monoxide (CO) & $71.9(28.4)$ & $68.7(25.2)$ & $72.3(23.9)$ \\
\hline Methane $\left(\mathrm{CH}_{4}\right)$ & $4.21(3.53)$ & $3.49(2.19)$ & $2.79(0.85)$ \\
\hline Acetylene $\left(\mathrm{C}_{2} \mathrm{H}_{2}\right)$ & $0.193(0.059)$ & $0.331(0.277)$ & $0.216(0.063)$ \\
\hline Ethylene $\left(\mathrm{C}_{2} \mathrm{H}_{4}\right)$ & $0.974(0.470)$ & $1.34(0.80)$ & $0.890(0.230)$ \\
\hline Propylene $\left(\mathrm{C}_{3} \mathrm{H}_{6}\right)$ & $0.417(0.224)$ & $0.576(0.415)$ & $0.492(0.094)$ \\
\hline Formaldehyde (HCHO) & $1.55(0.78)$ & $1.93(1.32)$ & $0.865(0.298)$ \\
\hline Methanol $\left(\mathrm{CH}_{3} \mathrm{OH}\right)$ & $2.24(1.33)$ & $1.87(1.53)$ & $1.01(0.37)$ \\
\hline Formic acid (HCOOH) & $0.840(0.571)$ & $0.633(0.846)$ & $0.119(0.055)$ \\
\hline Acetic acid $\left(\mathrm{CH}_{3} \mathrm{COOH}\right)$ & $3.80(2.35)$ & $3.88(3.64)$ & $0.871(0.719)$ \\
\hline Glycolaldehyde $\left(\mathrm{C}_{2} \mathrm{H}_{4} \mathrm{O}_{2}\right)$ & - & $2.29(3.04)$ & $4.07(4.03)$ \\
\hline Furan $\left(\mathrm{C}_{4} \mathrm{H}_{4} \mathrm{O}\right)$ & - & $0.355(0.445)$ & $0.116(0.049)$ \\
\hline Hydroxyacetone $\left(\mathrm{C}_{3} \mathrm{H}_{6} \mathrm{O}_{2}\right)$ & - & $1.69(2.03)$ & $1.48(0.62)$ \\
\hline Phenol $\left(\mathrm{C}_{6} \mathrm{H}_{5} \mathrm{OH}\right)$ & - & $0.494(0.480)$ & $0.341(0.170)$ \\
\hline 1,3-Butadiene $\left(\mathrm{C}_{4} \mathrm{H}_{6}\right)$ & $0.127(0.060)$ & $3.63 \times 10^{-3}\left(4.51 \times 10^{-3}\right)$ & $0.180(0.068)$ \\
\hline Isoprene $\left(\mathrm{C}_{5} \mathrm{H}_{8}\right)$ & - & $0.220(0.170)$ & $1.97 \times 10^{-2}\left(1.57 \times 10^{-2}\right)$ \\
\hline Ammonia $\left(\mathrm{NH}_{3}\right)$ & $1.48(1.13)$ & $1.10(1.05)$ & $1.32(1.10)$ \\
\hline Hydrogen cyanide $(\mathrm{HCN})$ & $0.134(0.252)$ & $0.381(0.259)$ & $0.630(0.463)$ \\
\hline Nitrous acid (HONO) & - & $0.395(0.221)$ & $0.377(0.084)$ \\
\hline Sulfur dioxide $\left(\mathrm{SO}_{2}\right)$ & - & $1.06(0.36)$ & $2.54(1.09)$ \\
\hline Hydrogen fluoride (HF) & - & - & bdl \\
\hline Hydrogen chloride $(\mathrm{HCl})$ & - & $0.472(0.320)$ & $2.65 \times 10^{-2}(-)$ \\
\hline Nitric oxide (NO) & $1.73(0.66)$ & $1.44(0.42)$ & $1.72(0.93)$ \\
\hline Nitrogen dioxide $\left(\mathrm{NO}_{2}\right)$ & $2.92(1.77)$ & $1.65(0.47)$ & $0.630(0.203)$ \\
\hline Ethane $\left(\mathrm{C}_{2} \mathrm{H}_{6}\right)$ & $0.764(0.414)$ & - & $0.566(-)$ \\
\hline Propane $\left(\mathrm{C}_{3} \mathrm{H}_{8}\right)$ & $0.237(0.126)$ & - & $0.186(-)$ \\
\hline 1-Butene $\left(\mathrm{C}_{4} \mathrm{H}_{8}\right)$ & $0.113(0.050)$ & $0.134(0.100)$ & $0.119(0.007)$ \\
\hline Benzene $\left(\mathrm{C}_{6} \mathrm{H}_{6}\right)$ & - & $0.301(0.177)$ & $0.379(0.091)$ \\
\hline Toluene $\left(\mathrm{C}_{7} \mathrm{H}_{8}\right)$ & - & $0.296(0.228)$ & $0.224(0.041)$ \\
\hline Ethylbenzene $\left(\mathrm{C}_{8} \mathrm{H}_{10}\right)$ & - & - & $6.24 \times 10^{-2}\left(4.05 \times 10^{-3}\right)$ \\
\hline m/p-Xylene $\left(\mathrm{C}_{8} \mathrm{H}_{10}\right)$ & - & $0.107(0.088)$ & $0.297(0.319)$ \\
\hline PM & $5.26(1.98)$ & - & - \\
\hline EF black carbon (BC) & - & - & $0.831(0.497)$ \\
\hline EF brown carbon $(\mathrm{BrC})$ & - & - & $10.9(6.5)$ \\
\hline $\mathrm{EF} B_{\mathrm{abs}} 405\left(\mathrm{~m}^{2} \mathrm{~kg}^{-1}\right)$ & - & - & $19.2(8.0)$ \\
\hline EF $B_{\text {scat }} 405\left(\mathrm{~m}^{2} \mathrm{~kg}^{-1}\right)$ & - & - & $116(80)$ \\
\hline $\mathrm{EF} B_{\mathrm{abs}} 870\left(\mathrm{~m}^{2} \mathrm{~kg}^{-1}\right)$ & - & - & $3.94(2.36)$ \\
\hline EF $B_{\text {scat }} 870\left(\mathrm{~m}^{2} \mathrm{~kg}^{-1}\right)$ & - & - & $33.1(29.5)$ \\
\hline $\mathrm{EF} B_{\text {abs }} 405$ just $\mathrm{BrC}\left(\mathrm{m}^{2} \mathrm{~kg}^{-1}\right)$ & - & - & $10.7(6.3)$ \\
\hline EF $B_{\text {abs }} 405$ just $\mathrm{BC}\left(\mathrm{m}^{2} \mathrm{~kg}^{-1}\right)$ & - & - & $8.47(5.06)$ \\
\hline SSA $405 \mathrm{~nm}$ & - & - & $0.818(0.146)$ \\
\hline SSA $870 \mathrm{~nm}$ & - & - & $0.825(0.082)$ \\
\hline AAE & - & - & $2.15(0.79)$ \\
\hline
\end{tabular}

a Yokelson et al. (2011) data are adjusted to a lower carbon fraction (0.42). ${ }^{\mathrm{b}}$ NAMaSTE gas-phase EF values are adjusted to MCE 0.925 (see Sect. 3.7).

${ }^{\mathrm{c}}$ Additional gas-phase compounds are in Table S9.

well et al., 2014) are significantly higher than from other BB sources (Burling et al., 2011; Johnson et al., 2013; Akagi et al., 2013). Glycolaldehyde was below the detection limit for one NAMaSTE crop type (mustard residue), sug- gesting emissions variability by fuel type and/or fuel properties. Our average glycolaldehyde EF $\left(4.07 \mathrm{~g} \mathrm{~kg}^{-1} \pm 4.03\right)$ is similar to typical EFs for total PM from BB, and glycolaldehyde has also been shown to be an efficient aque- 


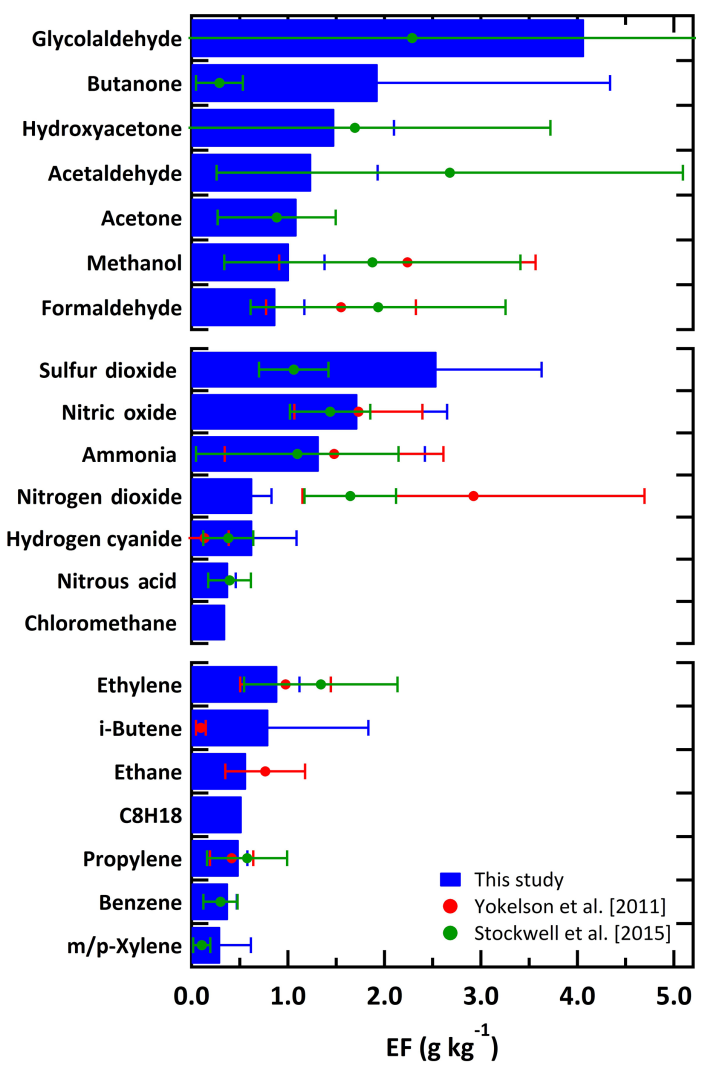

Figure 4. The emission factors $\left(\mathrm{g} \mathrm{kg}^{-1}\right)$ and \pm 1 standard deviation for the most abundant OVOCs, NMHCs, and S- or N-containing compounds emitted from crop residue burns. The crop residue fires from other studies (Yokelson et al., 2011; Stockwell et al., 2015) are shown in red and green.

ous phase SOA precursor (Ortiz-Montalvo et al., 2012). Other oxygenated species emitted in large amounts by the crop residues burned in NAMaSTE include butanone (methyl ethyl ketone) $\left(1.93 \pm 2.41 \mathrm{~g} \mathrm{~kg}^{-1}\right)$ and hydroxyacetone $\left(1.48 \pm 0.62 \mathrm{~g} \mathrm{~kg}^{-1}\right)$. The Nepal data are higher or similar to previous data for many OVOCs but noticeably lower for methanol, formaldehyde, and organic acids. As expected the emissions of OVOCs were greater than NMHCs, though there are also large emissions of $\mathrm{C}_{2}$ NMHCs and BTEX compounds.

Figure 4 shows several major S- and N-containing compounds including significant $\mathrm{SO}_{2}$ emissions $\left(2.54 \mathrm{~g} \mathrm{~kg}^{-1}\right)$. While the $\mathrm{SO}_{2}$ emissions are large compared to most $\mathrm{BB}$ types, the emissions from other S-containing compounds (OCS, DMS) are limited. $\mathrm{SO}_{2}$ is an important precursor of sulfate aerosols and was also a significant emission from grasses and crop residue in Stockwell et al. (2014). This update is important to include in emissions inventories as many global and regional estimates rely on the much smaller value $\left(0.4 \mathrm{~g} \mathrm{~kg}^{-1}\right)$ reported by Andreae and Merlet (2001) (Streets et al., 2003). Yokelson et al. (2011) noted high emissions of $\mathrm{NO}_{x}$ from crop residue fires sampled near the beginning of the Mexican dry season when plant $\mathrm{N}$ content may be higher. Our Nepal $\mathrm{NO}_{x}\left(\sim 2.5 \mathrm{~g} \mathrm{~kg}^{-1}\right)$ emissions for this fire type were measured in April, 6 months after the dry season started in October, and may reflect lower fuel $\mathrm{N}$ content. The higher $\mathrm{NO}_{x}$ emissions $\left(4.65 \mathrm{~g} \mathrm{~kg}^{-1}\right)$ in Mexico may have also reflected higher wind speed as an important mechanism, but one that requires airborne sampling to probe.

Unlike US crop residue fires (Stockwell et al., 2014), $\mathrm{HCl}$ remained below the detection limit in nearly every crop residue burn. As a landlocked country these crops are not as influenced by chlorine-rich maritime air. Additionally, in comparison to US crops, most rural agriculture in Nepal may be less augmented by chemical pesticides. There are, however, detectable emissions of $\mathrm{CH}_{3} \mathrm{Cl}$, which have not been measured previously in the field for crop residue burning. This new information for $\mathrm{CH}_{3} \mathrm{Cl}$ should be considered when assessing global emissions of reactive chlorine (Lobert et al., 1999).

The absorption and scattering coefficients at 405 and $870 \mathrm{~nm}$ were measured for five of the six crop residue fires. The fire-average SSA at $870 \mathrm{~nm}$ and AAE for these crop residue fires span a wide range. SSA (870) ranges from $0.579-0.981$ (average 0.82 for both 870 and $405 \mathrm{~nm}$ ), and AAE ranges from $\sim 1.58-3.53$ (average near 2). The AAE as a function of SSA colored by MCE is shown in Fig. 5 for all the real-time $1 \mathrm{~s}$ data collected during crop residue fires. The AAE increases sharply at high SSA, while the MCE distinctly decreases at increasing SSA. These observations support previous interpretations that $\mathrm{BrC}$ is produced primarily by smoldering combustion at lower MCEs for most BB fuel types (Liu et al., 2014; McMeeking et al., 2014). Similar trends were observed for all other fuel types except for the zigzag brick kiln, which will be discussed in the next section. The BC and OC literature average for crop residue fires reported by Akagi et al. (2011) was based on only two fires. Our average EF BC $\left(0.831 \pm 0.497 \mathrm{~g} \mathrm{~kg}^{-1}\right)$ from five crop residue fires is similar to the literature value $\left(0.75 \mathrm{~g} \mathrm{~kg}^{-1}\right)$, while we report the $\mathrm{EF}$ for $\mathrm{BrC}$ for the first time $\left(10.9 \pm 6.5 \mathrm{~g} \mathrm{~kg}^{-1}\right)$, which is considerably larger than the global average OC reported in Akagi et al. (2011) but in good agreement with the NAMaSTE, simultaneously measured filter organic mass $\left(\sim 10 \mathrm{~g} \mathrm{~kg}^{-1}\right)$ (Jayarathne et al., 2016). More importantly from an absorption standpoint, we report EFs for $B_{\text {abs }}$ and $B_{\text {scat }}$ at both wavelengths for this fuel type in column 4 of Table 5 .

\subsection{Brick kiln emissions}

Very little is known about the chemical composition of brick kiln emissions. There are very few studies and most of what is reported focuses on a few key pollutants including $\mathrm{CO}$, PM, and BC (Weyant et al., 2014). A previous study measured a larger suite of emissions from authentic brick kilns in Mexico (Christian et al., 2010); however, the fuel burned in those kilns was primarily biomass and the NMOC emissions 


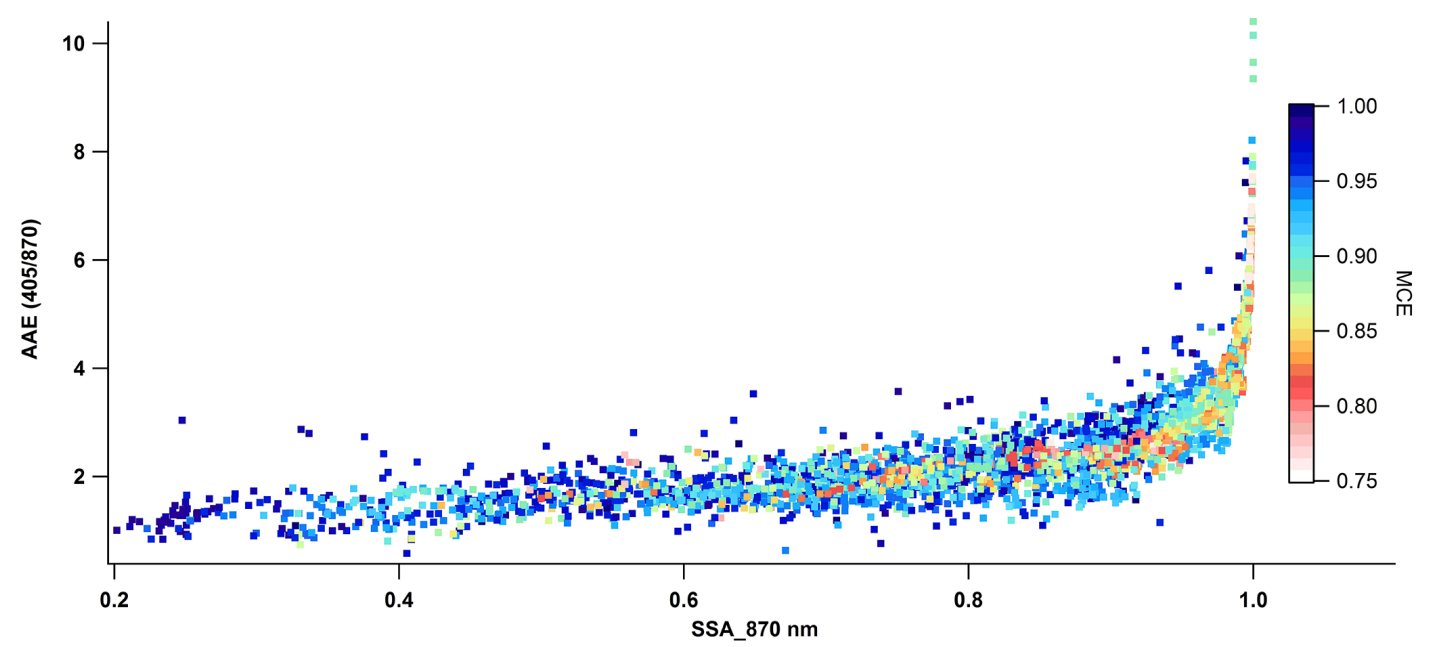

Figure 5. The AAE calculated at 405 and $870 \mathrm{~nm}$ vs. SSA at $870 \mathrm{~nm}$ for all crop residue burn samples measured every second during emissions collection. Each data point is colored by MCE. The AAE increases sharply at high SSA, while the MCE distinctly decreases at increasing SSA. BC emissions are associated mostly with high MCE flaming and BrC emissions are associated mostly with low MCE smoldering. Most source types demonstrated a similar trend.

were somewhat comparable to those from biomass burns. Coal is the main fuel used in brick kilns globally and to our knowledge NAMaSTE produced the first quantitative emissions data for numerous atmospherically significant species from authentic coal-fired brick kilns in a region heavily influenced by this source. The individual EFs for both brick kilns sampled in this study are reported in Table 6 . There are large differences between the two kilns types that stand out in Table 6 despite our lack of opportunity to measure inherent kiln variability. We will first discuss the kiln emissions individually and then follow with a detailed kiln comparison.

\subsubsection{Zigzag emissions}

The zigzag kiln emissions had a very high average MCE (0.994), and the EFs for most smoldering compounds (e.g., most NMOC) were much reduced. Not surprisingly, the EFs for flaming compounds including $\mathrm{HCl}, \mathrm{HF}, \mathrm{NO}_{x}$, and $\mathrm{SO}_{2}$ were high. High emissions of $\mathrm{NO}_{x}$ and S-containing gases are important as ozone and aerosol precursors and because they can enhance deposition and $\mathrm{O}_{3}$ impacts on nearby crops and negatively impact crop yield. The latter issue is especially relevant since brick kilns are commonly seasonal and located on land leased from farmers, where the depletion of the soil to collect clay for bricks is already another agricultural productivity issue.

The zigzag kiln was the only source in our NAMaSTE study that emitted detectable quantities of HF. It has been suspected that brick kilns are an important source of atmospheric fluorides since fluorine is typically present in raw brick materials (USEPA, 1997). We found that HF was a major emission from the zigzag brick kiln with an average EF of $0.629 \mathrm{~g} \mathrm{~kg}^{-1}$ and a peak concentration of $\sim 13 \mathrm{ppm}$. HF is a phytotoxic air pollutant, and agricultural areas with visible foliar damage in Pakistan were suspected to be impacted by HF emissions from nearby brick kilns (Ahmad et al., 2012). While HF is rapidly transformed to particulate fluoride, much previous work confirms adverse effects of HF or particulate fluoride from various sources on crops (Haidouti et al., 1993; Ahmad et al., 2012). Since many brick kilns are present in agricultural regions, this first confirmation of high HF emissions is an important finding and should also be included in assessments of kiln impacts on agriculture. HF emissions from brick kilns likely vary considerably depending on the $\mathrm{F}$ content of the clay (and possibly the coal) being fired (as discussed further below). HF is also very reactive, but perhaps particle fluoride could serve as a regional indicator for brick kilns with more work.

Because of the large number of FTIR grab samples over the sampling day, which lasted approximately $5 \mathrm{~h}$, we can construct a rough time series of the kiln emissions, with resolution averaging about $12 \mathrm{~min}$. To emphasize chemistry, normalize for fuel consumption rates, and account for somewhat arbitrary grab sample dilution, in Fig. S1 we plot selected ERs to $\mathrm{CO}_{2}$. The ERs of $\mathrm{HCl}$ and $\mathrm{HF}$ to $\mathrm{CO}_{2}$ rise first and track together over time. The ERs of $\mathrm{NO}$ and $\mathrm{SO}_{2}$ rise next, and their observed peak is about $2 \mathrm{~h}$ after the halogens. This is consistent with the halogens being driven from clay at 500-600 ${ }^{\circ} \mathrm{C}$ (USEPA, 1997). The halogen peaks are then followed by a peak in the $\mathrm{NO}_{x}$ and $\mathrm{SO}_{2}$ emissions likely from the coal fuel.

As noted in Sect. 2.1.7, in hopes of obtaining representative emissions from this particular brick kiln, we sampled the smoke coming out of the top of the chimney stack, but we also sampled the lesser amount of emissions escaping the coal-feeder stoke holes located on the "roof" of the kiln. Ta- 
Table 6. Emission factors $\left(\mathrm{g} \mathrm{kg}^{-1}\right)$ for a single clamp kiln, zigzag kiln, and stoke holes on the zigzag kiln.

\begin{tabular}{|c|c|c|c|}
\hline Compound (formula) & EF clamp kiln & EF zigzag kiln & $\begin{array}{r}\text { EF coal stoke holes } \\
\text { at zigzag kiln }\end{array}$ \\
\hline Method & FTIR + WAS & FTIR + WAS & FTIR \\
\hline MCE & 0.950 & 0.994 & 0.861 \\
\hline Carbon dioxide $\left(\mathrm{CO}_{2}\right)$ & 2102 & 2620 & 2234 \\
\hline Carbon monoxide (CO) & 70.9 & 10.1 & 230 \\
\hline Methane $\left(\mathrm{CH}_{4}\right)$ & 19.5 & $8.73 \times 10^{-2}$ & 4.59 \\
\hline Acetylene $\left(\mathrm{C}_{2} \mathrm{H}_{2}\right)$ & $5.58 \times 10^{-2}$ & $1.65 \times 10^{-2}$ & $1.87 \times 10^{-2}$ \\
\hline Ethylene $\left(\mathrm{C}_{2} \mathrm{H}_{4}\right)$ & 1.27 & $4.32 \times 10^{-2}$ & 0.445 \\
\hline Propylene $\left(\mathrm{C}_{3} \mathrm{H}_{6}\right)$ & 1.49 & $6.58 \times 10^{-2}$ & 0.808 \\
\hline Formaldehyde (HCHO) & $8.21 \times 10^{-2}$ & bdl & bdl \\
\hline Methanol $\left(\mathrm{CH}_{3} \mathrm{OH}\right)$ & 1.77 & 0.112 & 0.437 \\
\hline Formic acid $(\mathrm{HCOOH})$ & 0.241 & $5.84 \times 10^{-2}$ & 0.180 \\
\hline Acetic acid $\left(\mathrm{CH}_{3} \mathrm{COOH}\right)$ & 0.430 & 0.471 & 11.3 \\
\hline Glycolaldehyde $\left(\mathrm{C}_{2} \mathrm{H}_{4} \mathrm{O}_{2}\right)$ & bdl & bdl & bdl \\
\hline Furan $\left(\mathrm{C}_{4} \mathrm{H}_{4} \mathrm{O}\right)$ & 0.383 & bdl & bdl \\
\hline Hydroxyacetone $\left(\mathrm{C}_{3} \mathrm{H}_{6} \mathrm{O}_{2}\right)$ & 1.81 & bdl & 1.61 \\
\hline Phenol $\left(\mathrm{C}_{6} \mathrm{H}_{5} \mathrm{OH}\right)$ & 0.429 & $1.54 \times 10^{-2}$ & bdl \\
\hline 1,3-Butadiene $\left(\mathrm{C}_{4} \mathrm{H}_{6}\right)$ & 0.103 & $1.51 \times 10^{-2}$ & bdl \\
\hline Isoprene $\left(\mathrm{C}_{5} \mathrm{H}_{8}\right)$ & $8.66 \times 10^{-2}$ & $2.46 \times 10^{-2}$ & 1.47 \\
\hline Ammonia $\left(\mathrm{NH}_{3}\right)$ & 0.317 & bdl & bdl \\
\hline Hydrogen cyanide (HCN) & 1.39 & 0.446 & 2.28 \\
\hline Nitrous acid (HONO) & 0.320 & $4.45 \times 10^{-2}$ & 1.33 \\
\hline Sulfur dioxide $\left(\mathrm{SO}_{2}\right)$ & 13.0 & 12.7 & 28.5 \\
\hline Hydrogen fluoride (HF) & bdl & 0.629 & 0.888 \\
\hline Hydrogen chloride $(\mathrm{HCl})$ & bdl & 1.24 & 1.86 \\
\hline Nitric oxide (NO) & bdl & 1.28 & 10.4 \\
\hline Nitrogen dioxide $\left(\mathrm{NO}_{2}\right)$ & 0.297 & $8.21 \times 10^{-2}$ & 1.36 \\
\hline Carbonyl sulfide (OCS) & - & $3.42 \times 10^{-3}$ & $\mathrm{~nm}$ \\
\hline $\operatorname{DMS}\left(\mathrm{C}_{2} \mathrm{H}_{6} \mathrm{~S}\right)$ & - & $3.68 \times 10^{-5}$ & $\mathrm{~nm}$ \\
\hline Chloromethane $\left(\mathrm{CH}_{3} \mathrm{Cl}\right)$ & - & $2.22 \times 10^{-2}$ & $\mathrm{~nm}$ \\
\hline Bromomethane $\left(\mathrm{CH}_{3} \mathrm{Br}\right)$ & $2.62 \times 10^{-3}$ & $2.59 \times 10^{-3}$ & $\mathrm{~nm}$ \\
\hline Methyl iodide $\left(\mathrm{CH}_{3} \mathrm{I}\right)$ & bdl & $2.01 \times 10^{-3}$ & $\mathrm{~nm}$ \\
\hline 1,2-Dichloroethene $\left(\mathrm{C}_{2} \mathrm{H}_{2} \mathrm{Cl}_{2}\right)$ & - & $4.45 \times 10^{-5}$ & $\mathrm{~nm}$ \\
\hline Methyl nitrate $\left(\mathrm{CH}_{3} \mathrm{NO}_{3}\right)$ & $2.36 \times 10^{-5}$ & $2.92 \times 10^{-3}$ & $\mathrm{~nm}$ \\
\hline Ethane $\left(\mathrm{C}_{2} \mathrm{H}_{6}\right)$ & 5.37 & $2.06 \times 10^{-3}$ & $\mathrm{~nm}$ \\
\hline Propane $\left(\mathrm{C}_{3} \mathrm{H}_{8}\right)$ & 3.00 & $1.97 \times 10^{-3}$ & $\mathrm{~nm}$ \\
\hline i-Butane $\left(\mathrm{C}_{4} \mathrm{H}_{10}\right)$ & 0.342 & $1.60 \times 10^{-3}$ & $\mathrm{~nm}$ \\
\hline n-Butane $\left(\mathrm{C}_{4} \mathrm{H}_{10}\right)$ & 1.16 & $1.92 \times 10^{-3}$ & $\mathrm{~nm}$ \\
\hline 1-Butene $\left(\mathrm{C}_{4} \mathrm{H}_{8}\right)$ & 0.347 & $1.68 \times 10^{-3}$ & $\mathrm{~nm}$ \\
\hline i-Butene $\left(\mathrm{C}_{4} \mathrm{H}_{8}\right)$ & 0.428 & $1.47 \times 10^{-3}$ & $\mathrm{~nm}$ \\
\hline trans-2-Butene $\left(\mathrm{C}_{4} \mathrm{H}_{8}\right)$ & 0.346 & $1.44 \times 10^{-3}$ & $\mathrm{~nm}$ \\
\hline cis-2-Butene $\left(\mathrm{C}_{4} \mathrm{H}_{8}\right)$ & 0.214 & $9.65 \times 10^{-4}$ & $\mathrm{~nm}$ \\
\hline i-Pentane $\left(\mathrm{C}_{5} \mathrm{H}_{12}\right)$ & 0.349 & $3.70 \times 10^{-2}$ & $\mathrm{~nm}$ \\
\hline n-Pentane $\left(\mathrm{C}_{5} \mathrm{H}_{12}\right)$ & 0.811 & $3.26 \times 10^{-2}$ & $\mathrm{~nm}$ \\
\hline 1-Pentene $\left(\mathrm{C}_{5} \mathrm{H}_{10}\right)$ & 0.233 & $1.60 \times 10^{-3}$ & $\mathrm{~nm}$ \\
\hline trans-2-Pentene $\left(\mathrm{C}_{5} \mathrm{H}_{10}\right)$ & 0.249 & $2.64 \times 10^{-3}$ & $\mathrm{~nm}$ \\
\hline cis-2-Pentene $\left(\mathrm{C}_{5} \mathrm{H}_{10}\right)$ & 0.093 & $9.01 \times 10^{-4}$ & $\mathrm{~nm}$ \\
\hline 3-Methyl-1-butene $\left(\mathrm{C}_{5} \mathrm{H}_{10}\right)$ & $5.72 \times 10^{-2}$ & $3.32 \times 10^{-4}$ & $\mathrm{~nm}$ \\
\hline 1,2-Propadiene $\left(\mathrm{C}_{3} \mathrm{H}_{4}\right)$ & $4.97 \times 10^{-4}$ & $2.15 \times 10^{-5}$ & $\mathrm{~nm}$ \\
\hline Propyne $\left(\mathrm{C}_{3} \mathrm{H}_{4}\right)$ & $1.80 \times 10^{-3}$ & bdl & $\mathrm{nm}$ \\
\hline 1-Butyne $\left(\mathrm{C}_{4} \mathrm{H}_{6}\right)$ & bdl & bdl & $\mathrm{nm}$ \\
\hline 2-Butyne $\left(\mathrm{C}_{4} \mathrm{H}_{6}\right)$ & bdl & bdl & $\mathrm{nm}$ \\
\hline n-Hexane $\left(\mathrm{C}_{6} \mathrm{H}_{14}\right)$ & 0.670 & $2.16 \times 10^{-2}$ & $\mathrm{~nm}$ \\
\hline n-Heptane $\left(\mathrm{C}_{7} \mathrm{H}_{16}\right)$ & 0.617 & $3.04 \times 10^{-3}$ & $\mathrm{~nm}$ \\
\hline
\end{tabular}


Table 6. Continued.

\begin{tabular}{|c|c|c|c|}
\hline Compound (formula) & EF clamp kiln & EF zigzag kiln & $\begin{array}{r}\text { EF coal stoke holes } \\
\text { at zigzag kiln }\end{array}$ \\
\hline n-Octane $\left(\mathrm{C}_{8} \mathrm{H}_{18}\right)$ & 0.549 & $1.58 \times 10^{-3}$ & $\mathrm{~nm}$ \\
\hline n-Nonane $\left(\mathrm{C}_{9} \mathrm{H}_{20}\right)$ & 0.434 & $2.42 \times 10^{-3}$ & $\mathrm{~nm}$ \\
\hline n-Decane $\left(\mathrm{C}_{10} \mathrm{H}_{22}\right)$ & 0.428 & $2.02 \times 10^{-3}$ & $\mathrm{~nm}$ \\
\hline 2,3-Dimethylbutane $\left(\mathrm{C}_{6} \mathrm{H}_{14}\right)$ & 0.127 & $3.59 \times 10^{-3}$ & $\mathrm{~nm}$ \\
\hline 2-Methylpentane $\left(\mathrm{C}_{6} \mathrm{H}_{14}\right)$ & 0.398 & $4.84 \times 10^{-3}$ & $\mathrm{~nm}$ \\
\hline 3-Methylpentane $\left(\mathrm{C}_{6} \mathrm{H}_{14}\right)$ & 0.312 & $1.17 \times 10^{-2}$ & $\mathrm{~nm}$ \\
\hline 2,2,4-Trimethylpentane $\left(\mathrm{C}_{8} \mathrm{H}_{18}\right)$ & bdl & $8.02 \times 10^{-4}$ & $\mathrm{~nm}$ \\
\hline Cyclopentane $\left(\mathrm{C}_{5} \mathrm{H}_{10}\right)$ & 0.134 & $8.53 \times 10^{-4}$ & $\mathrm{~nm}$ \\
\hline Cyclohexane $\left(\mathrm{C}_{6} \mathrm{H}_{12}\right)$ & $5.55 \times 10^{-2}$ & $2.98 \times 10^{-3}$ & $\mathrm{~nm}$ \\
\hline Methylcyclohexane $\left(\mathrm{C}_{7} \mathrm{H}_{14}\right)$ & $5.84 \times 10^{-2}$ & bdl & $\mathrm{nm}$ \\
\hline Benzene $\left(\mathrm{C}_{6} \mathrm{H}_{6}\right)$ & 1.68 & $8.25 \times 10^{-3}$ & $\mathrm{~nm}$ \\
\hline Toluene $\left(\mathrm{C}_{7} \mathrm{H}_{8}\right)$ & 1.05 & $2.80 \times 10^{-2}$ & $\mathrm{~nm}$ \\
\hline Ethylbenzene $\left(\mathrm{C}_{8} \mathrm{H}_{10}\right)$ & 0.279 & $1.35 \times 10^{-2}$ & $\mathrm{~nm}$ \\
\hline m/p-Xylene $\left(\mathrm{C}_{8} \mathrm{H}_{10}\right)$ & 1.06 & $5.74 \times 10^{-2}$ & $\mathrm{~nm}$ \\
\hline o-Xylene $\left(\mathrm{C}_{8} \mathrm{H}_{10}\right)$ & 0.377 & $2.18 \times 10^{-2}$ & $\mathrm{~nm}$ \\
\hline Styrene $\left(\mathrm{C}_{8} \mathrm{H}_{8}\right)$ & $2.62 \times 10^{-3}$ & $4.56 \times 10^{-3}$ & $\mathrm{~nm}$ \\
\hline i-Propylbenzene $\left(\mathrm{C}_{9} \mathrm{H}_{12}\right)$ & $2.84 \times 10^{-2}$ & $4.07 \times 10^{-4}$ & $\mathrm{~nm}$ \\
\hline n-Propylbenzene $\left(\mathrm{C}_{9} \mathrm{H}_{12}\right)$ & $3.82 \times 10^{-2}$ & $1.82 \times 10^{-3}$ & $\mathrm{~nm}$ \\
\hline 3-Ethyltoluene $\left(\mathrm{C}_{9} \mathrm{H}_{12}\right)$ & 0.091 & $6.93 \times 10^{-3}$ & $\mathrm{~nm}$ \\
\hline 4-Ethyltoluene $\left(\mathrm{C}_{9} \mathrm{H}_{12}\right)$ & $3.55 \times 10^{-2}$ & $3.69 \times 10^{-3}$ & $\mathrm{~nm}$ \\
\hline 2-Ethyltoluene $\left(\mathrm{C}_{9} \mathrm{H}_{12}\right)$ & $2.76 \times 10^{-2}$ & $2.30 \times 10^{-3}$ & $\mathrm{~nm}$ \\
\hline 1,3,5-Trimethylbenzene $\left(\mathrm{C}_{9} \mathrm{H}_{12}\right)$ & $5.88 \times 10^{-2}$ & $4.30 \times 10^{-3}$ & $\mathrm{~nm}$ \\
\hline 1,2,4-Trimethylbenzene $\left(\mathrm{C}_{9} \mathrm{H}_{12}\right)$ & $8.46 \times 10^{-2}$ & $5.59 \times 10^{-3}$ & $\mathrm{~nm}$ \\
\hline 1,2,3-Trimethylbenzene $\left(\mathrm{C}_{9} \mathrm{H}_{12}\right)$ & $2.76 \times 10^{-2}$ & $2.03 \times 10^{-3}$ & $\mathrm{~nm}$ \\
\hline alpha-Pinene $\left(\mathrm{C}_{10} \mathrm{H}_{16}\right)$ & bdl & $1.49 \times 10^{-3}$ & $\mathrm{~nm}$ \\
\hline beta-Pinene $\left(\mathrm{C}_{10} \mathrm{H}_{16}\right)$ & bdl & $1.31 \times 10^{-3}$ & $\mathrm{~nm}$ \\
\hline Ethanol $\left(\mathrm{C}_{2} \mathrm{H}_{6} \mathrm{O}\right)$ & - & $4.84 \times 10^{-3}$ & $\mathrm{~nm}$ \\
\hline Acetaldehyde $\left(\mathrm{C}_{2} \mathrm{H}_{4} \mathrm{O}\right)$ & $4.13 \times 10^{-2}$ & $6.94 \times 10^{-2}$ & $\mathrm{~nm}$ \\
\hline Acetone $\left(\mathrm{C}_{3} \mathrm{H}_{6} \mathrm{O}\right)$ & - & $1.46 \mathrm{E}-01$ & $\mathrm{~nm}$ \\
\hline Butanal $\left(\mathrm{C}_{4} \mathrm{H}_{8} \mathrm{O}\right)$ & bdl & $2.19 \times 10^{-3}$ & $\mathrm{~nm}$ \\
\hline Butanone $\left(\mathrm{C}_{4} \mathrm{H}_{8} \mathrm{O}\right)$ & - & $2.29 \times 10^{-3}$ & $\mathrm{~nm}$ \\
\hline EF black carbon (BC) & $1.72 \times 10^{-2}\left(7.50 \times 10^{-3}\right)$ & $0.112(0.063)$ & $\mathrm{nm}$ \\
\hline EF brown carbon $(\mathrm{BrC})$ & $1.74(0.34)$ & $0.913(0.278)$ & $\mathrm{nm}$ \\
\hline EF $B_{\text {abs }} 405\left(\mathrm{~m}^{2} \mathrm{~kg}^{-1}\right)$ & $1.86(0.24)$ & $2.03(0.70)$ & $\mathrm{nm}$ \\
\hline EF $B_{\text {scat }} 405\left(\mathrm{~m}^{2} \mathrm{~kg}^{-1}\right)$ & $32.8(2.1)$ & $21.2(12.8)$ & $\mathrm{nm}$ \\
\hline $\mathrm{EF} B_{\mathrm{abs}} 870\left(\mathrm{~m}^{2} \mathrm{~kg}^{-1}\right)$ & $8.16 \times 10^{-2}\left(3.56 \times 10^{-2}\right)$ & $0.530(0.300)$ & $\mathrm{nm}$ \\
\hline EF $B_{\text {scat }} 870\left(\mathrm{~m}^{2} \mathrm{~kg}^{-1}\right)$ & $0.670(0.129)$ & $1.75(0.25)$ & $\mathrm{nm}$ \\
\hline $\mathrm{EF} B_{\mathrm{abs}} 405$ just $\mathrm{BrC}\left(\mathrm{m}^{2} \mathrm{~kg}^{-1}\right)$ & $1.70(0.33)$ & $0.895(0.273)$ & $\mathrm{nm}$ \\
\hline EF $B_{\text {abs }} 405$ just $\mathrm{BC}\left(\mathrm{m}^{2} \mathrm{~kg}^{-1}\right)$ & $0.155(0.102)$ & $1.14(0.64)$ & $\mathrm{nm}$ \\
\hline SSA $405 \mathrm{~nm}$ & $0.946(0.007)$ & $0.881(0.098)$ & $\mathrm{nm}$ \\
\hline SSA $870 \mathrm{~nm}$ & $0.895(0.029)$ & $0.779(0.103)$ & $\mathrm{nm}$ \\
\hline AAE & $4.19(0.73)$ & $1.92(0.50)$ & $\mathrm{nm}$ \\
\hline
\end{tabular}

Note: "bdl" indicates below the detection limit; "-_" indicates concentrations were not greater than background; "nm" indicates not measured; C fractions: zigzag kiln (0.722), clamp kiln (0.644) (see Sect. 2.4).

ble 6 also includes the EFs specific to the emissions from the stoke holes. The MCE is significantly reduced (0.861); consequently, the EFs of smoldering compounds are much higher with, e.g., high EF CO $\left(230 \mathrm{~g} \mathrm{~kg}^{-1}\right)$. Oddly, the stoke hole smoke also had higher $\mathrm{EFs}$ for $\mathrm{HF}, \mathrm{HCl}, \mathrm{NO}_{x}$, and $\mathrm{SO}_{2}$, compounds normally emitted during flaming combustion.
This is probably because the stoke holes are much closer to the combustion zone, and many internally generated species are scavenged in the kiln and stack walls before being emitted from the stack. Some kilns have internal water reservoirs below the stack to scavenge the smoke as rudimentary emissions control. However, these stoke hole emissions do not 


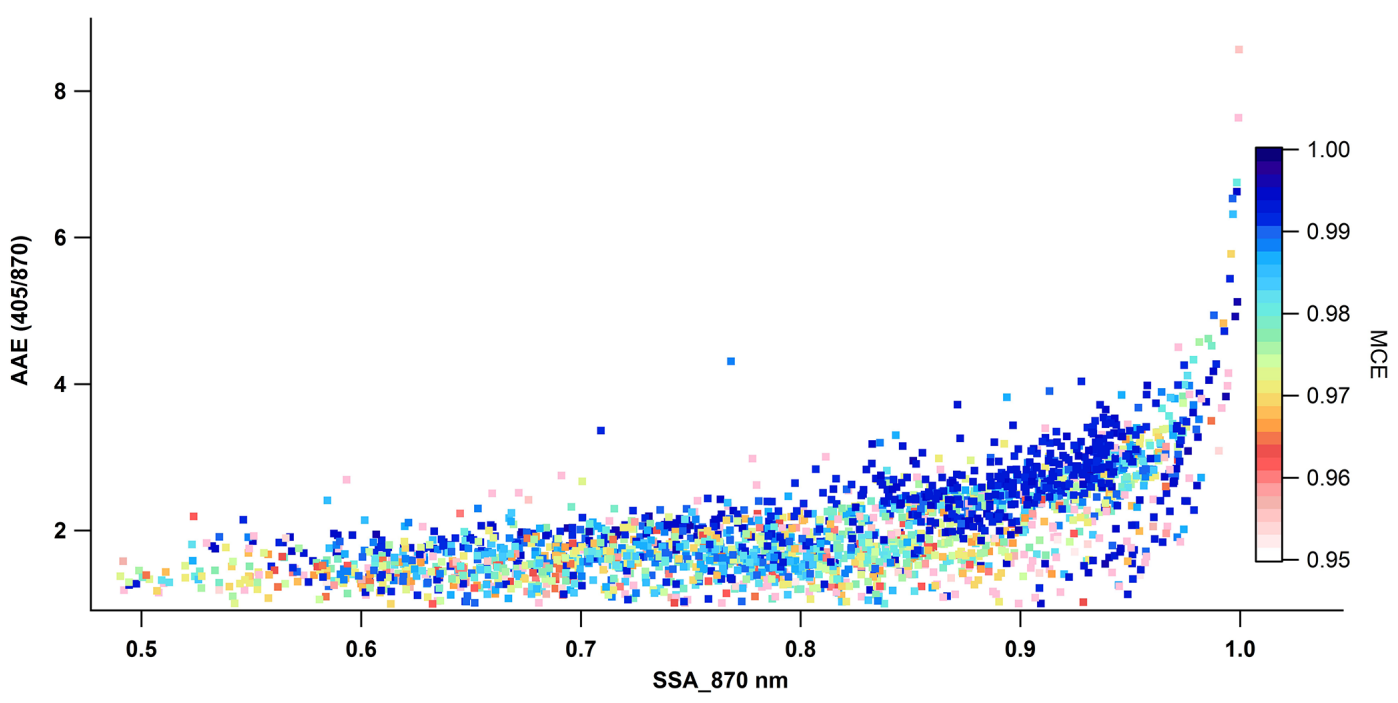

Figure 6. The AAE calculated at 405 and $870 \mathrm{~nm}$ vs. SSA at $870 \mathrm{~nm}$ for the zigzag kiln measured every second during emissions collection. Each data point is colored by MCE. This deviates from the typical trend in that the highest MCEs are not clustered at the lowest SSA or AAEs. Some BrC is emitted at a variety of "higher" MCEs.

need to be weighted much if at all in an assessment of overall emissions as the vents are normally closed.

Table 6 includes the $\mathrm{EFs}$ for $\mathrm{BC}$ and $\mathrm{BrC}$, and the $\mathrm{EFs}$ for scattering and absorption at 405 and $870 \mathrm{~nm}$, calculated from all the real-time PAX (and colocated $\mathrm{CO}_{2}$ ) data above background for separate plumes throughout the sampling day, that we then averaged together. The SSA at $870 \mathrm{~nm}$ $(0.779 \pm 0.103)$ indicates that $\mathrm{BC}$ contributes to the absorption in the fresh emissions, while the AAE (1.92 \pm 0.50$)$ implies that the emissions are not pure BC. The PAX data suggest that a little under half the absorption at $405 \mathrm{~nm}$ is due to BrC. Weyant et al. (2014) reported a range of EFs for EC for South Asian brick kilns $\left(0.01-3.7 \mathrm{~g} \mathrm{~kg}^{-1}\right)$ and our EF BC $\left(0.112 \mathrm{~g} \mathrm{~kg}^{-1}\right)$ falls within the range they report. We note that for all the other sources sampled in NAMaSTE and in the BB literature, high values of SSA and AAE are mostly associated with a low MCE (smoldering) and low SSA and AAE is associated with high MCE (flaming). This is illustrated for crop residues in Fig. 5. For the zigzag kiln this pattern is less pronounced. In the zigzag kiln, the highest MCE values are not clustered at the lowest SSA and AAE (Fig. 6). Nearly all the real-time data from the zigzag kilns was at high MCE (>0.95) but accompanied by some evidence for $\mathrm{BrC}$ emissions. Given the plethora of possible UV-absorbing compounds in $\mathrm{OA}$, characterizing the variety of primary and secondary "BrC types" with different absorption intensities, abundances, and lifetimes is an important area for future research (Saleh et al., 2014).

\subsubsection{Clamp kiln emissions}

The clamp kiln emissions had a lower average MCE (0.950) than the zigzag kiln (though still reflecting primarily efficient combustion), which is not surprising since we estimate that the fuel had a larger component of biomass. Consequently the EFs for most products of incomplete combustion are $\sim 5-$ 3000 times higher than those from the zigzag kiln and also higher than values reported for a clamp kiln in Mexico that burned mostly sawdust at an average MCE of 0.968 (Christian et al., 2010). Even though the MCE was lower, the clamp kiln $\mathrm{EF} \mathrm{SO}_{2}\left(13.0 \mathrm{~g} \mathrm{~kg}^{-1}\right)$ was almost the same as the zigzag kiln. This is most likely rationalized at least in part by the higher sulfate emission factors for the zigzag kiln (Jayarathne et al., 2016). For all grab samples of the clamp kiln, the NO remained below the detection limit, while $\mathrm{NO}_{2}$ only had detectable quantities for three grab samples near the end of the day. $\mathrm{HCl}$ and $\mathrm{HF}$ probably remained below the detection limit because of lower halogen content in the clay (vide infra and Table S3).

If we convert and sum the $\mathrm{NO}_{2}, \mathrm{NO}$, and $\mathrm{HONO}$ emissions to " $\mathrm{NO}_{x}$ as NO", this quantity is more than 3.5 times higher from the zigzag kiln. The coal from both kilns had similar $\mathrm{N}$ content, so the difference in $\mathrm{NO}_{x}$ emissions is most likely traced to the higher MCE in the zigzag kiln. However, we cannot completely rule out a different contribution of "thermal $\mathrm{NO}_{x}$ " between the kilns. Co-firing coal with biomass is a common practice in power plants as it has been shown to decrease combustion zone temperature and thermally dependent $\mathrm{NO}_{x}$ formation, thereby reducing several criteria pollutants including $\mathrm{NO}_{x}$ (USEPA, 2007; Al-Naiema et al., 2015). Thus, the lower $\mathrm{NO}_{x}$ EFs from the clamp kiln could be partly due to co-firing with more biomass.

The differences in NMOC emissions for the two kiln types were dramatic. We simply list some common pollutants and precursors of concern and include the approximate clampkiln-to-zigzag-kiln EF ratio in parentheses after each: $\mathrm{CO}$ 
(7), $\mathrm{CH}_{4}$ (223), ethane (2604), ethylene (30), benzene (203), methanol (16), and phenol (28). In addition, many species were emitted at high levels from the clamp kiln but were below the detection limit from the zigzag kiln, including formaldehyde, furan, hydroxyacetone, and ammonia. The main emissions overall from the clamp kiln in order of mass were $\mathrm{CO}_{2}, \mathrm{CO}, \mathrm{CH}_{4}, \mathrm{SO}_{2}$, ethane, propane, hydroxyacetone, $\mathrm{BrC}$, methanol, and benzene. Methane is an important shortlived climate pollutant, and the $\mathrm{CH}_{4} \mathrm{EF}$ for the clamp kiln $\left(19.5 \mathrm{~g} \mathrm{~kg}^{-1}\right)$ is among the highest seen for any combustion source. The other alkanes were also extremely enhanced all the way through $n$-decane, which had an EF of $0.428 \mathrm{~g} \mathrm{~kg}^{-1}$. These enormous EFs for alkanes are not typical for BB and might reflect burning coal inefficiently. Another possible explanation is that used motor oil is reportedly sometimes disposed of as fuel in brick kilns or added to the fuel to impart color to bricks (USEPA, 1997; Christian et al., 2010). The enhancement observed for the alkanes throughout the $\mathrm{C}_{1}-\mathrm{C}_{10}$ size range that we could measure suggests that even larger alkanes are also enhanced. Large alkanes have recently attracted attention as important SOA precursors (Presto et al., 2010). In our clamp kiln data, the sum of the EFs for NMOCs we measured that are known to have high yields for SOA (BTEX plus phenol) is $\sim 5 \mathrm{~g} \mathrm{~kg}^{-1}$, which is already much larger than the initial EF OA as crudely approximated from the $\mathrm{EF} \operatorname{BrC}\left(\sim 2.0 \pm 0.4 \mathrm{~g} \mathrm{~kg}^{-1}\right)$.

The EF BC $\left(0.02 \mathrm{~g} \mathrm{~kg}^{-1}\right)$ for the clamp kiln was much lower than for the zigzag kiln, and the co-collected filter data are consistent with this result. Weyant et al. (2014) also noted similar "low" EFs for EC for several brick kilns measured in that study. The $\mathrm{EF} \mathrm{BrC}$ was greater for the clamp kiln than the zigzag kiln, which is consistent with the filter OC and an expected result given a more significant biomass contribution to overall fuel. The AAE and SSA were much greater for the clamp kiln than the zigzag kiln (Table 6).

We had only one sample of the coal from each kiln, and the elemental analysis is shown in Table S3. The likely higher fuel variability for the non-C trace substances limits us to a few general comments. The measured emissions of the sulfur species from both kilns (including stoke holes) accounted for about $60-111 \%$ of the nominal $\mathrm{S}$ in the coal, which is a good match given experimental uncertainty. The measured emissions of N-containing species from both kilns were significantly lower than the nominal coal N. Much of the missing N was likely emitted as $\mathrm{N}_{2}$, especially at high MCE (Kuhlbusch et al., 1991; Burling et al., 2010). Finally, the zigzag kiln emissions had significantly higher halogen content than the $0.3 \mathrm{~g} \mathrm{~kg}^{-1}$ upper limit for the zigzag coal. This is consistent with our speculation above that much of the halogen emissions come from the clay and that this is a source of kiln-tokiln variability.

This is by no means an exhaustive evaluation of South Asian brick kiln emissions. However, because there are so few studies detailing the chemical composition of brick kiln emissions, this is a valuable addition to the current body of measurements. In terms of comparative pollution between the two technologies, there are some trade-offs. The clamp kiln we sampled produced far more $\mathrm{BrC}$ and a large suite of NMOC pollutants and precursors typically associated with inefficient combustion of biomass (e.g., HCHO and benzene) or (likely) inefficient combustion of motor oil or coal (e.g., alkanes). The zigzag kiln we sampled produced significantly more $\mathrm{BC}, \mathrm{NO}_{x}, \mathrm{HCl}$, and $\mathrm{HF}$, where the latter two could be larger partly because of the clay and not only the kiln design. For $\mathrm{SO}_{2}$ the kilns were not significantly different. Ultimately, since the zigzag kiln is thought to produce significantly more bricks per unit fuel use than the clamp kiln (e.g., Weyant et al., 2014), this ratio should be further investigated for scaling emissions (on a per brick basis). The zigzag kiln is very likely preferred from the standpoint of pollutants emitted per brick produced, which is a major factor in selecting mitigation strategies. More measurement and modeling studies will clearly be needed to fully assess the impact of brick kiln emissions and subsequent atmospheric chemistry in the region.

\section{Conclusions}

We investigated the trace gas and aerosol emissions from a large suite of major undersampled sources around Kathmandu and the Indo-Gangetic plain of southern Nepal. Our source characterization included motorcycles, kilns, wood and dung cooking fires, crop residue burning, diesel and gasoline generators, agricultural pumps, and open garbage burning. We report the emission factors (grams of compound emitted per kilogram of dry fuel burned) for $\sim 80$ important trace gases measured by FTIR and WAS, including important NMHCs up to $\mathrm{C}_{10}$ and many oxygenated organic compounds. We also measured aerosol mass and optical properties using two PAX systems at 405 and $870 \mathrm{~nm}$. We report important aerosol optical properties that include emission factors (in $\mathrm{m}^{2} \mathrm{~kg}^{-1}$ ) for scattering and absorption at 405 and $870 \mathrm{~nm}$, single scattering albedo, and absorption Ångström exponent. From the direct measurements of absorption we estimated black and brown carbon emission factors (in $\mathrm{g} \mathrm{kg}^{-1}$ ).

Although we were not able to sample the transport sector extensively due to the Gorkha earthquake, we were able to measure several motorbikes pre- and post-service. The minor maintenance led to minimal if any reduction in gaseous pollutants, consistent with the idea that more major servicing is needed to reduce gas-phase pollutants. Motorcycles were in general among the least efficient sources sampled, and the CO EF was on the order of $\sim 700 \mathrm{~g} \mathrm{~kg}^{-1}$, about 10 times that of a typical biomass fire. For most fossil fuel sources, including generators and agricultural pumps, diesel burned more efficiently than gas but produced more $\mathrm{NO}_{x}, \mathrm{HCHO}$, and aerosol. 
Numerous trace gas emissions (many for the first time in the field) were quantified for open cooking fires and several improved cooking stoves with several fuel variations. Authentic open dung cooking fires emitted high levels of $\operatorname{BrC}\left(5.54 \pm 1.66 \mathrm{~g} \mathrm{~kg}^{-1}\right), \mathrm{NH}_{3}\left(3.00 \pm 1.33 \mathrm{~g} \mathrm{~kg}^{-1}\right)$, organic acids $\left(7.66 \pm 6.90 \mathrm{~g} \mathrm{~kg}^{-1}\right)$, and $\mathrm{HCN}\left(2.01 \pm 1.25 \mathrm{~g} \mathrm{~kg}^{-1}\right)$, where the latter could contribute to space-based observations of high levels of $\mathrm{HCN}$ in the lower stratosphere above the Asian monsoon. $\mathrm{HCN}$ and some alkynes $>\mathrm{C}_{2}$ (previously linked to $\mathrm{BB}$ ) were also observed from several non-biomass burning sources. BTEX compounds were major emissions of both dung $\left(\sim 4.5 \mathrm{~g} \mathrm{~kg}^{-1}\right)$ and wood $\left(\sim 1.5 \mathrm{~g} \mathrm{~kg}^{-1}\right)$ cooking fires and a simple method to estimate indoor exposure to the many important air toxics we measured in the emissions is described. Our PAX data suggest relatively more absorption by $\mathrm{BrC}$ as opposed to $\mathrm{BC}$ from cooking fires than may be currently recognized, especially for dung burning. Biogas, as expected, emerged as the most efficient and least polluting cooking technology out of approximately a dozen types subjected to limited testing.

The first global garbage burning inventory relied on measurements from very few studies and information for many compounds is often limited to laboratory simulations (Wiedinmyer et al., 2014). Our authentic Nepali garbage burning data shift the global average observed for this source to lower $\mathrm{MCE}$ and significantly more BC and BTEX emissions than in previous measurements, while supporting previous measurements of high $\mathrm{HCl}$. Crop residue burning produced EFs in good agreement with literature values with relatively high emissions of oxygenated organic compounds $\left(\sim 12 \mathrm{~g} \mathrm{~kg}^{-1}\right)$ and $\mathrm{SO}_{2}\left(2.54 \pm 1.09 \mathrm{~g} \mathrm{~kg}^{-1}\right)$. We observed an $\mathrm{EF}$ for $\mathrm{BrC}$ of $\sim 11 \mathrm{~g} \mathrm{~kg}^{-1}$ or about 4 times higher than the previous organic carbon literature average, which was based on fewer data. Our $\mathrm{EF} \mathrm{BrC}$ is qualitative but in agreement with our absorption data and SSA in showing that $\mathrm{BrC}$ absorption is important for this major global BB type.

There are very few studies detailing the chemical emissions from brick kilns. While we were only able to sample two brick kilns in this study, we present a significant expansion in chemical speciation data. The two brick kilns sampled had different designs and utilized different clay, coal, and amounts of biomass for co-firing with the main coal fuel. Consequently the two kilns produced very different emissions. A zigzag kiln burning primarily coal at high efficiency produced larger amounts of $\mathrm{BC}, \mathrm{NO}_{x}, \mathrm{HF}$, and $\mathrm{HCl}$, (the halogen compounds likely mostly from the clay), while the clamp kiln (with relatively more biomass fuel) produced dramatically more organic gases, organic aerosol (BrC), and aerosol precursors including large alkanes. Both kilns were significant $\mathrm{SO}_{2}$ sources, with their emission factors averaging $\sim 13 \mathrm{~g} \mathrm{~kg}^{-1}$.

Overall, we report the first, or in any case rare, optically and chemically detailed emissions data for many undersampled biomass burning sources and other undersampled sources in developing countries. Companion papers will re- port results from other co-deployed techniques, such as filter sampling and mini-AMS, a source apportionment for a fixed supersite, and model interpretation as guidance for mitigation strategies. In summary, we have provided the first extensive suite of gases for most of the sources. For cooking fires and crop residue burning, which are major South Asian and global sources, we have shown that absorption by both $\mathrm{BrC}$ and $\mathrm{BC}$ is significant, with $\mathrm{BrC}$ absorption even more pronounced for dung fuel compared to wood fuel. On the other hand, though we have begun to address these undersampled sources, given the diversity and abundance of the sources, much more work is needed, especially for gensets, pumps, traffic, and brick kilns. Future measurements and modeling are also needed to better understand the evolution of the emissions we report here.

\section{Data availability}

Additional "raw" data not in the tables or Supplement will be archived and available after publication of our initial papers. Contact the corresponding author or future NAMaSTE papers for updates or details.

\section{The Supplement related to this article is available online at doi:10.5194/acp-16-11043-2016-supplement.}

Acknowledgements. Chelsea E. Stockwell, Ted J. Christian, Robert J. Yokelson, purchase of the PAXs, WAS analyses, and many other NAMaSTE-associated expenses were supported by NSF grant AGS-1349976. Robert J. Yokelson, Donald R. Blake, and Isobel J. Simpson were also supported by NASA Earth Science Division Award NNX14AP45G. Thilina Jayarathne and Elizabeth A. Stone were supported by NSF grant AGS-1351616. J. Douglas Goetz and Peter F. DeCarlo were supported by NSF grant AGS-1461458. Prakash V. Bhave, Puppala S. Praveen, Sagar Adhikari, Rashmi Maharjan, and Arnico K. Panday were partially supported by core funds of ICIMOD contributed by the governments of Afghanistan, Australia, Austria, Bangladesh, Bhutan, China, India, Myanmar, Nepal, Norway, Pakistan, Switzerland, and the United Kingdom. Eri Saikawa was supported by NSF grant AGS-1350021. We thank G. McMeeking, J. Walker, and S. Murphy for helpful discussions on the PAX instruments and data; S. B. Dangol, S. Dhungel, S. Ghimire, and M. Rai for identifying and arranging access to the field sampling sites; B. R. Khanal for assisting with the lab-based cooking tests; and Nawraj and K. Sherpa for logistic support.

Edited by: Sachin S. Gunthe

Reviewed by: three anonymous referees 


\section{References}

Abel, S. J., Haywood, J. M., Highwood, E. J., Li, J., and Buseck, P. R.: Evolution of biomass burning aerosol properties from an agricultural fire in southern Africa, Geophys. Res. Lett., 30, 1783, doi:10.1029/2003GL017342, 2003.

Adhikary, B., Carmichael, G. R., Tang, Y., Leung, L. R., Qian, Y., Schauer, J. J., Stone, E. A., Ramanathan, V., and Ramana, M. V.: Characterization of the seasonal cycle of south Asian aerosols: A regional-scale modeling analysis, J. Geophys. Res., 112, D22S22, doi:10.1029/2006JD008143, 2007.

Adhikary, B., Carmichael, G. R., Kulkarni, S., Wei, C., Tang, Y., D'Allura, A., Mena-Carrasco, M., Streets, D. G., Zhang, Q., Pierce, R. B., Al-Saadi, J. A., Emmons, L. K., Pfister, G. G., Avery, M. A., Barrick, J. D., Blake, D. R., Brune, W. H., Cohen, R. C., Dibb, J. E., Fried, A., Heikes, B. G., Huey, L. G., O'Sullivan, D. W., Sachse, G. W., Shetter, R. E., Singh, H. B., Campos, T. L., Cantrell, C. A., Flocke, F. M., Dunlea, E. J., Jimenez, J. L., Weinheimer, A. J., Crounse, J. D., Wennberg, P. O., Schauer, J. J., Stone, E. A., Jaffe, D. A., and Reidmiller, D. R.: A regional scale modeling analysis of aerosol and trace gas distributions over the eastern Pacific during the INTEX-B field campaign, Atmos. Chem. Phys., 10, 2091-2115, doi:10.5194/acp-10-20912010, 2010.

Ahmad, M. N., van den Berg, L. J. L., Shah, H. U., Masood, T., Büker, P., Emberson, L., and Ashmore, M.: Hydrogen fluoride damage to vegetation from peri-urban brick kilns in Asia: A growing but unrecognised problem?, Environ. Pollut., 162, 319324, doi:10.1016/j.envpol.2011.11.017, 2012.

Akagi, S. K., Yokelson, R. J., Wiedinmyer, C., Alvarado, M. J., Reid, J. S., Karl, T., Crounse, J. D., and Wennberg, P. O.: Emission factors for open and domestic biomass burning for use in atmospheric models, Atmos. Chem. Phys., 11, 4039-4072, doi:10.5194/acp-11-4039-2011, 2011.

Akagi, S. K., Craven, J. S., Taylor, J. W., McMeeking, G. R., Yokelson, R. J., Burling, I. R., Urbanski, S. P., Wold, C. E., Seinfeld, J. H., Coe, H., Alvarado, M. J., and Weise, D. R.: Evolution of trace gases and particles emitted by a chaparral fire in California, Atmos. Chem. Phys., 12, 1397-1421, doi:10.5194/acp-12-13972012, 2012.

Akagi, S. K., Yokelson, R. J., Burling, I. R., Meinardi, S., Simpson, I., Blake, D. R., McMeeking, G. R., Sullivan, A., Lee, T., Kreidenweis, S., Urbanski, S., Reardon, J., Griffith, D. W. T., Johnson, T. J., and Weise, D. R.: Measurements of reactive trace gases and variable $\mathrm{O}_{3}$ formation rates in some South Carolina biomass burning plumes, Atmos. Chem. Phys., 13, 1141-1165, doi:10.5194/acp-13-1141-2013, 2013.

Akagi, S. K., Burling, I. R., Mendoza, A., Johnson, T. J., Cameron, M., Griffith, D. W. T., Paton-Walsh, C., Weise, D. R., Reardon, J., and Yokelson, R. J.: Field measurements of trace gases emitted by prescribed fires in southeastern US pine forests using an open-path FTIR system, Atmos. Chem. Phys., 14, 199-215, doi:10.5194/acp-14-199-2014, 2014.

Allen, R. J., Sherwood, S. C., Norris, J. R., and Zender, C. S.: Recent Northern Hemisphere tropical expansion primarily driven by black carbon and tropospheric ozone, Nature, 485, 350-354, doi:10.1038/nature11097, 2012.

Al-Naiema, I., Estillore, A. D., Mudunkotuwa, I. A., Grassian, V. H., and Stone, E. A.: Impacts of co-firing biomass on emis- sions of particulate matter to the atmosphere, Fuel, 162, 111120, doi:10.1016/j.fuel.2015.08.054, 2015.

Alvarado, M. J., Lonsdale, C. R., Yokelson, R. J., Akagi, S. K., Coe, H., Craven, J. S., Fischer, E. V., McMeeking, G. R., Seinfeld, J. H., Soni, T., Taylor, J. W., Weise, D. R., and Wold, C. E.: Investigating the links between ozone and organic aerosol chemistry in a biomass burning plume from a prescribed fire in California chaparral, Atmos. Chem. Phys., 15, 6667-6688, doi:10.5194/acp15-6667-2015, 2015.

Andreae, M. O. and Merlet, P.: Emission of trace gases and aerosols from biomass burning, Global Biogeochem. Cy., 15, 955-966, doi:10.1029/2000GB001382, 2001.

Arnott, W. P., Moosmüller, H., and Walker, J. W.: Nitrogen dioxide and kerosene-flame soot calibration of photoacoustic instruments for measurement of light absorption by aerosols, Rev. Sci. Instrum. 71, 4545-4552, 2000.

Arnott, W. P., Walker, J. W., Moosmüller, H., Elleman, R. A., Jonsson, H. H., Buzorius, G., Conant, W. C., Flagan, R. C., and Seinfeld, R. H.: Photoacoustic insight for aerosol light absorption aloft from meteorological aircraft and comparison with particle soot absorption photometer measurements: DOE Southern Great Plains climate research facility and the coastal stratocumulus imposed perturbation experiments, J. Geophys. Res., 111, 1-16, doi:10.1029/2005JD005964, 2006.

Arola, A., Schuster, G., Myhre, G., Kazadzis, S., Dey, S., and Tripathi, S. N.: Inferring absorbing organic carbon content from AERONET data, Atmos. Chem. Phys., 11, 215-225, doi:10.5194/acp-11-215-2011, 2011.

Barker, R. and Molle, F.: Evolution of Irrigation in South and Southeast Asia, Comprehensive Assessment of Water Management in Agriculture Research Report No. 5, International Water management Institute, Colombo, Sri Lanka, 2004.

Beaton, S. P., Bishop, G. A., and Stedman, D. H.: Emissions characteristics of Mexico City vehicles, J. Air Waste Manage., 42, 1424-1429, doi:10.1080/10473289.1992.10467088, 1992.

Bertschi, I. T., Yokelson, R. J., Ward, D. E., Christian, T. J., and Hao, W. M.: Trace gas emissions from the production and use of domestic biofuels in Zambia measured by open-path Fourier transform infrared spectroscopy, J. Geophys. Res., 108, 8469, doi:1029/2002/D002158, 2003.

Bond, T. C. and Bergstrom, R.: Light absorption by carbonaceous particles: An investigative review, Aerosol Sci. Technol., 40, 2767, doi:10.1080/02786820500421521, 2006.

Bond, T. C., Doherty, S. J., Fahey, D.W., Forster, P. M., Berntsen, T., DeAngelo, B. J., Flanner, M. G.,Ghan, S., Kärcher, B., Koch, D., Kinne, S., Kondo, Y., Quinn, P. K., Sarofim, M. C., Schultz, M. G., Schulz, M., Venkataraman, C., Zhang, H., Zhang, S., Bellouin, N., Guttikunda, S. K., Hopke, P. K., Jacobson, M. Z., Kaiser, J. W., Klimont, Z., Lohmann, U., Schwarz, J. P., Shindell, D., Storelvmo, T., Warren, S. G., and Zender, C. S.: Bounding the role of black carbon in the climate system: A scientific assessment, J. Geophys. Res., 118, 5380-5552, doi:10.1002/jgrd.50171, 2013.

Burling, I. R., Yokelson, R. J., Griffith, D. W. T., Johnson, T. J., Veres, P., Roberts, J. M., Warneke, C., Urbanski, S. P., Reardon, J., Weise, D. R., Hao, W. M., and de Gouw, J.: Laboratory measurements of trace gas emissions from biomass burning of fuel types from the southeastern and southwestern United 
States, Atmos. Chem. Phys., 10, 11115-11130, doi:10.5194/acp10-11115-2010, 2010.

Burling, I. R., Yokelson, R. J., Akagi, S. K., Urbanski, S. P., Wold, C. E., Griffith, D. W. T., Johnson, T. J., Reardon, J., and Weise, D. R.: Airborne and ground-based measurements of the trace gases and particles emitted by prescribed fires in the United States, Atmos. Chem. Phys., 11, 12197-12216, doi:10.5194/acp11-12197-2011, 2011.

Chen, P., Kang, S., Li, C., Rupakheti, M., Yan, F., Li, Q., Ji, Z., Zhang, Q., Luo, W., and Sillanpää, M.: Characteristics and sources of polycyclic aromatic hydrocarbons in atmospheric aerosols in the Kathmandu Valley, Nepal, Sci. Total Environ., 538, 86-92, doi:10.1016/j.scitotenv.2015.08.006, 2015.

Chen, Y. and Bond, T. C.: Light absorption by organic carbon from wood combustion, Atmos. Chem. Phys., 10, 1773-1787, doi:10.5194/acp-10-1773-2010, 2010.

Chiang, H., Tsai, J., Yao, Y., and Ho, W.: Deterioration of gasoline vehicle emissions and effectiveness of tune-up for high-polluted vehicles, Transport Res. D-Tr. E., 13, 47-53, doi:10.1016/j.trd.2007.07.004, 2008.

Christian, T., Kleiss, B., Yokelson, R. J., Holzinger, R., Crutzen, P. J., Hao, W. M., Saharjo, B. H., and Ward, D. E.: Comprehensive laboratory measurements of biomass-burning emissions: 1. Emissions from Indonesian, African, and other fuels, J. Geophys. Res., 108, 4719, doi:10.1029/2003JD003704, 2003.

Christian, T. J., Yokelson, R. J., Carvalho Jr., J. A., Griffith, D. W. T., Alvarado, E. C., Santos, J. C., Neto, T. G. S., Veras, C. A. G., and Hao, W. M.: The tropical forest and fire emissions experiment: Trace gases emitted by smoldering logs and dung on deforestation and pasture fires in Brazil, J. Geophys. Res., 112, D18308, doi:10.1029/2006JD008147, 2007.

Christian, T. J., Yokelson, R. J., Cárdenas, B., Molina, L. T., Engling, G., and Hsu, S.-C.: Trace gas and particle emissions from domestic and industrial biofuel use and garbage burning in central Mexico, Atmos. Chem. Phys., 10, 565-584, doi:10.5194/acp10-565-2010, 2010.

Clairotte, M., Adam, T. W., Chirico, R., Giechaskiel, B., Manfredi, U., Elsasser, M., Sklorz, M., DeCarlo, P. F., Heringa, M. F., Zimmermann, R., Martini, G., Krasenbrink, A., Vicet, A., Tournié, E., Prevot, A. S. H., and Astorga, C.: Online characterization of regulated and unregulated gaseous and particulate exhaust emissions from two-stroke mopeds: A chemometric approach, Anal. Chim. Acta, 717, 28-38, doi:10.1016/j.aca.2011.12.029, 2012.

Clarke, A. D., Noone, K. J., Heintzenberg, J., Warren, S. G., and. Covert, D. S: Aerosol light absorption measurement techniques: Analysis and intercomparisons, Atmos. Environ., 21, 1455-1465, doi:10.1016/0004-6981(67)90093-5, 1987.

Collins, W. J., Fry, M. M., Yu, H., Fuglestvedt, J. S., Shindell, D. T., and West, J. J.: Global and regional temperature-change potentials for near-term climate forcers, Atmos. Chem. Phys., 13, 2471-2485, doi:10.5194/acp-13-2471-2013, 2013.

Costner, P.: Estimating Releases and Prioritizing Sources in the Context of the Stockholm Convention: Dioxin Emission Factors for Forest Fires, Grassland and Moor Fires, Open Burning of Agricultural Residues, Open Burning of Domestic Waste, Landfill and Dump Fires, The International POPs Elimination Project, Mexico, 1-40, 2005.

Crounse, J. D., DeCarlo, P. F., Blake, D. R., Emmons, L. K., Campos, T. L., Apel, E. C., Clarke, A. D., Weinheimer, A. J., Mc-
Cabe, D. C., Yokelson, R. J., Jimenez, J. L., and Wennberg, P. O.: Biomass burning and urban air pollution over the Central Mexican Plateau, Atmos. Chem. Phys., 9, 4929-4944, doi:10.5194/acp-9-4929-2009, 2009.

Davidson, C. I., Lin, S., Osborn, J. F., Pandey, M. R., Rasmussen, R. A., and Khalil, M. A. K.: Indoor and outdoor air pollution in the Himalayas, Environ. Sci. Technol., 20, 561-567, doi:10.1021/es00148a003, 1986.

Dickerson, R. R., Andreae, M. O., Campos, T., Mayol-Bracero, O. L., Neusuess C., and Streets, D. G.: Analysis of black carbon and carbon monoxide observed over the Indian Ocean: Implications for emissions and photochemistry, J. Geophys. Res., 107, 8017, doi:10.1029/2001JD000501, 2002.

Duffy, B. L. and Nelson, P. F.: Non-methane exhaust composition in the Sydney harbor tunnel: A focus on benzene and 1,3butadiene, Atmos. Environ., 30, 2759-2768, doi:10.1016/13522310(95)00372-X, 1996.

Dunmore, R. E., Hopkins, J. R., Lidster, R. T., Lee, J. D., Evans, M. J., Rickard, A. R., Lewis, A. C., and Hamilton, J. F.: Diesel-related hydrocarbons can dominate gas phase reactive carbon in megacities, Atmos. Chem. Phys., 15, 9983-9996, doi:10.5194/acp-15-9983-2015, 2015.

Escalambre, R: A Technican's Guide to Advanced Automotive Emissions Systems, Delmar, Publishers, Albany, USA, 256 pp. 1995.

Feng, Y., Ramanathan, V., and Kotamarthi, V. R.: Brown carbon: a significant atmospheric absorber of solar radiation?, Atmos. Chem. Phys., 13, 8607-8621, doi:10.5194/acp-13-8607-2013, 2013.

Fernandes, S. M., Trautmann, N. M., Streets, D. G., Roden, C. A., and Bond, T. C.: Global biofuel use, 1850-2000, Global Biogeochem. Cy., 21, GB2019, doi:10.1029/2006GB002836, 2007.

Franco, V., Kousoulidou, M., Muntean, M., Ntziachristos, L., Hausberger, S., and Dilara, P.: Road vehicle emission factors development: A review, Atmos. Environ., 70, 84-97, doi:10.1016/j.atmosenv.2013.01.006, 2013.

Fullerton, D. G., Bruce, N., and Gordon, S. B.: Indoor air pollution from biomass fuel smoke is a major health concern in the developing world, T. Roy. Soc. Trop. Med. H., 102, 843-851, doi:10.1016/j.trstmh.2008.05.028, 2008.

Glatthor, N., Höpfner, M., Stiller, G. P., von Clarmann, T., Funke, B., Lossow, S., Eckert, E., Grabowski, U., Kellmann, S., Linden, A., A. Walker, K., and Wiegele, A.: Seasonal and interannual variations in $\mathrm{HCN}$ amounts in the upper troposphere and lower stratosphere observed by MIPAS, Atmos. Chem. Phys., 15, 563582, doi:10.5194/acp-15-563-2015, 2015.

Goetz, J. D., Giordano, M. R., Stockwell, C. E., Maharjan, R., Adhikari, S., Bhave, P. V., Praveen, P. S., Panday, A. K., Jayarathne, T., Stone, E. A., Yokelson, R. J., and DeCarlo, P. F.: Speciated aerosol emission factors and mass spectral characterization of South Asian combustion sources, in preparation, 2016.

Griffith, D. W. T.: Synthetic calibration and quantitative analysis of gas phase infrared spectra, Appl. Spectrosc., 50, 59-70, 1996.

Gullett, B. K., Touati, A., Oudejans, L., and Ryan, S. P.: Real-time emission characterization of organic air toxic pollutants during steady state and transient operation of a medium duty diesel engine, Atmos. Environ., 40, 4037-4047, doi:10.1016/j.atmosenv.2006.03.031, 2006. 
Guo, H., Wang, T., Blake, D. R., Simpson, I. J., Kwok, Y. H., and Li, Y. S.: Regional and local contributions to ambient nonmethane volatile organic compounds at a polluted rural/coastal site in Pearl River Delta, China, Atmos. Environ., 40, 23452359, doi:10.1016/j.atmosenv.2005.12.011, 2006.

Haidouti, C., Chronopoulou, A., and Chronopoulos, J.: Effects of fluoride emissions from industry on the fluoride concentration of soils and vegetation, Biochem. Syst. Ecol., 21, 195-208, doi:10.1016/0305-1978(93)90037-R, 1993.

Hatch, L. E., Luo, W., Pankow, J. F., Yokelson, R. J., Stockwell, C. E., and Barsanti, K. C.: Identification and quantification of gaseous organic compounds emitted from biomass burning using two-dimensional gas chromatography-time-of-flight mass spectrometry, Atmos. Chem. Phys., 15, 1865-1899, doi:10.5194/acp15-1865-2015, 2015.

Hecobian, A., Zhang, X., Zheng, M., Frank, N., Edgerton, E. S., and Weber, R. J.: Water-Soluble Organic Aerosol material and the light-absorption characteristics of aqueous extracts measured over the Southeastern United States, Atmos. Chem. Phys., 10, 5965-5977, doi:10.5194/acp-10-5965-2010, 2010.

Ho, K. F., Lee, S. C., Ho, W. K., Blake, D. R., Cheng, Y., Li, Y. S., Ho, S. S. H., Fung, K., Louie, P. K. K., and Park, D.: Vehicular emission of volatile organic compounds (VOCs) from a tunnel study in Hong Kong, Atmos. Chem. Phys., 9, 7491-7504, doi:10.5194/acp-9-7491-2009, 2009.

Holmén, B. A. and Niemeier, D. A.: Characterizing the effects of driver variability on real-world vehicle emissions, Transport Res. D-Tr. E., 3, 117-128, doi:10.1016/S1361-9209(97)00032$1,1998$.

Iyer, N. V.: A Technical Assessment of Emissions and Fuel Consumption Reduction Potential from Two and Three Wheelers in India, The International Council on Clean Transportation, Washington, D. C., USA, available at: http://www.theicct.org/sites/default/files/publications/Iyer_ two-three-wheelers_India_August2012.pdf (last access: 2 September 2016), 2012.

Jayarathne, T., Stockwell, C. E., Christian, T. J., Bhave, P. V., Rathnayake, C.; Islam, M. R.; Praveen, P. S., Panday, A. K., Adhikari, S., Maharjan, R., Goetz, J. D., DeCarlo, P. F., Saikawa, E., Yokelson, R. J., and Stone E. A.: Nepal Ambient Monitoring and Source Testing Experiment (NAMaSTE): Emissions of particulate matter from wood and dung cooking fires, garbage and crop residue burning, and other sources, in preparation, 2016.

Johnson, T. J., Sams, R. L., Profeta, L. T. M., Akagi, S. K., Burling, I. R., Williams, S. D., and Yokelson, R. J.: Quantitative IR spectrum and vibrational assignments for glycolaldehyde: Application to measurements in biomass burning plumes, J. Phys. Chem. A, 117, 4096-4107, doi:10.1021/jp311945p, 2013.

Katuwal, H. and Bohara, A. K.: Biogas: A promising renewable technology and its impact on rural households in Nepal, Renew. Sust. Energ. Rev., 13, 2668-2674, doi:10.1016/j.rser.2009.05.002, 2009.

Keene, W. C., Lobert, J. M., Crutzen, P. J., Maben, J. R., Scharffe, D. H., Landmann, T., Hély, C., and Brain, C.: Emissions of major gaseous and particulate species during experimental burns of southern African biomass, J. Geophys. Res., 111, D04301, doi:10.1029/2005JD006319, 2006.

Kettle, A. J., Kuhn, U., von Hobe, M., Kesselmeier, J., and Andreae, M. O.: Global budget of atmospheric carbonyl sulfide: Temporal and spatial variations of the dominant sources and sinks, J. Geophys. Res., 107, 4658, doi:10.1029/2002JD002187, 2002.

Kirchstetter, T. W., Harley, R. A., Kreisberg, N. M., Stolzenburg, M. R., and Hering, S. V.: On-road measurement of fine particle and nitrogen oxide emission from light- and heavy-duty motor vehicles, Atmos. Environ., 33, 2955-2968, doi:10.1016/S13522310(99)00089-8, 1999.

Kirchstetter, T. W., Novakov, T., and Hobbs, P. V.: Evidence that the spectral dependence of light absorption by aerosols is affected by organic carbon, J. Geophys. Res., 109, D21208, doi:10.1029/2004JD004999, 2004.

Kuhlbusch, T. A., Lobert, J. M., Crutzen, P. J., and Warneck, P.: Molecular nitrogen emissions from denitrification during biomass burning, Nature, 351, 135-137, doi:10.1038/351135a0, 1991.

Lack, D. A. and Langridge, J. M.: On the attribution of black and brown carbon light absorption using the Ångström exponent, Atmos. Chem. Phys., 13, 10535-10543, doi:10.5194/acp13-10535-2013, 2013.

Lei, W., Li, G., and Molina, L. T.: Modeling the impacts of biomass burning on air quality in and around Mexico City, Atmos. Chem. Phys., 13, 2299-2319, doi:10.5194/acp-13-2299-2013, 2013.

Lewis, K., Arnott, W. P., Moosmüller, H., and Wold, C. E.: Strong spectral variation of biomass smoke light absorption and single scattering albedo observed with a novel dual-wavelength photoacoustic instrument, J. Geophys. Res., 113, D16203, doi:10.1029/2007jd009699, 2008.

Li, G., Lei, W., Bei, N., and Molina, L. T.: Contribution of garbage burning to chloride and $\mathrm{PM}_{2.5}$ in Mexico City, Atmos. Chem. Phys., 12, 8751-8761, doi:10.5194/acp-12-8751-2012, 2012.

Li, Q., Jacob, D. J., Bey, I., Yantosca, R. M., Zhao, Y., Kondo, Y., and Notholt, J.: Atmospheric hydrogen cyanide (HCN): biomass burning source, ocean sink?, Geophys. Res. Lett., 27, 357-360, doi:10.1029/1999GL010935, 2000.

Liu, S., Aiken, A. C., Arata, C., Manvendra, K. D., Stockwell, C. E., Yokelson, R. J., Stone, E. A., Jayarathne, T., Robinson, A. L., DeMott, P. J., and Kreidenweis, S. M.: Aerosol single scattering albedo dependence on biomass combustion efficiency: Laboratory and field studies, Geophys. Res. Lett., 41, 742-748, doi:10.1002/2013GL058392, 2014.

Liu, X., Zhang, Y., Huey, L. G., Yokelson, R. J., Wang, Y., Jimenez, J.-L., Campuzano-Jost, P., Beyersdorf, A., Blake, D., Choi, Y., St. Clair, J., Crounse, J., Day, D. A., Diskin, G., Fried, A., Hall, S., Hanisco, T., King, L., Meinardi, S., Mikoviny, T., Palm, B., Peischl, J., Perring, A., Pollack, I., Ryerson, T., Sachse, G., Schwarz, J., Simpson, I., Tanner, D., Thornhill, K., Ullmann, K., Weber, R., Wennberg, P., Wisthaler, A., Wolfe, G., and Ziemba, L.: Agricultural fires in the southeastern US during SEAC ${ }^{4} \mathrm{RS}$ : Emissions of trace gases and particles and evolution of ozone, reactive nitrogen, and organic aerosol, J. Geophys. Res., 121, 7383-7414, doi:10.1002/2016JD025040, 2016.

Liu, Y., Shao, M., Fu, L., Lu, S., Zeng, L., and Tang, D.: Source profiles of volatile organic compounds (VOCs) measured in China: Part I, Atmos. Environ., 42, 6247-6260, doi:10.1016/j.atmosenv.2008.01.070, 2008.

Lloyd, A. C. and Cackette, T. A.: Diesel engines: Environmental impact and control, J. Air Waste Manage., 51, 809-847, doi:10.1080/10473289.2001.10464315, 2001. 
Lobert, J. M., Keene, W. C., Logan, J. A., and Yevich, R.: Global chlorine emissions from biomass burning: Reactive Chlorine Emissions Inventory, J. Geophys. Res., 104, 8373-8389, doi:10.1029/1998JD100077, 1999.

Lüthi, Z. L., Škerlak, B., Kim, S.-W., Lauer, A., Mues, A., Rupakheti, M., and Kang, S.: Atmospheric brown clouds reach the Tibetan Plateau by crossing the Himalayas, Atmos. Chem. Phys., 15, 6007-6021, doi:10.5194/acp-15-6007-2015, 2015.

Lyu, X., Guo, H., Simpson, I. J., Meinardi, S., Louie, P. K. K., Ling, Z., Wang, Y., Liu, M., Luk, C. W. Y., Wang, N., and Blake, D. R.: Effectiveness of replacing catalytic converters in LPG-fueled vehicles in Hong Kong, Atmos. Chem. Phys., 16, 6609-6626, doi:10.5194/acp-16-6609-2016, 2016.

Maithel, S., Lalchandani, D., Malhotra, G., Bhanware, P., Uma, R., Ragavan, S., Athalye, V., Bindiya, K. R, Reddy, S., Bond, T., Weyant, C., Baum, E., Thoa, V. T. K., Phuong, N. T., and Thanh, T. K.: Brick Kilns Performance Assessment, Greentech, New Delhi, India, 164 pp., 2012.

May, A. A., Lee, T., McMeeking, G. R., Akagi, S., Sullivan, A. P., Urbanski, S., Yokelson, R. J., and Kreidenweis, S. M.: Observations and analysis of organic aerosol evolution in some prescribed fire smoke plumes, Atmos. Chem. Phys., 15, 6323-6335, doi:10.5194/acp-15-6323-2015, 2015.

McMeeking, G. R., Fortner, E., Onasch T. B., Taylor, J. W., Flynn, M., Coe, H., and Kreidenweis, S. M.: Impacts of nonrefractory material on light absorption by aerosols emitted from biomass burning, J. Geophys. Res.-Atmos., 119, 12272-12286, doi:10.1002/2014JD021750, 2014.

Menon, S., Koch, D., Beig, G., Sahu, S., Fasullo, J., and Orlikowski, D.: Black carbon aerosols and the third polar ice cap, Atmos. Chem. Phys., 10, 4559-4571, doi:10.5194/acp-10-4559-2010, 2010.

Molina, L. T. and Molina, M. J. (Eds.): Air Quality in the Mexico Megacity: An Integrated Assessment, Kluwer Academic Publishers, Dordrecht, the Netherlands, 2002.

Molina, M. J. and Molina, L. T.: Megacities and Atmospheric Pollution, J. Air Waste Manage., 54, 6, 644-680, 2004.

Molina, L. T., Kolb, C. E., de Foy, B., Lamb, B. K., Brune, W. H., Jimenez, J. L., Ramos-Villegas, R., Sarmiento, J., ParamoFigueroa, V. H., Cardenas, B., Gutierrez-Avedoy, V., and Molina, M. J.: Air quality in North America's most populous city overview of the MCMA-2003 campaign, Atmos. Chem. Phys., 7, 2447-2473, doi:10.5194/acp-7-2447-2007, 2007.

MOPIT: Details of Registration of Transport Fiscal Year 2046/472070/74, Ministry of Physical Infrastructure and Transport, Government of Nepal, Kathmandu, 2014.

Morikawa, T., Wakamatsu, S., Tanaka, M., Uno, I., Kamiura, T., and Maeda, T.: $\mathrm{C}_{2}-\mathrm{C}_{5}$ Hydrocarbon concentrations in central Osaka, Atmos. Environ., 32, 2007-2016, doi:10.1016/S13522310(97)00509-8, 1998.

Moussa, S. G., Leithead, A., Li, S.-M., Chan, T. W., Wentzell, J. J. B., Stroud, C., Zhang, J., Lee, P., Lu, G., Brook, J. R., Hayden, K., Narayan, J., and Liggio J.: Emissions of hydrogen cyanide from on-road gasoline and diesel vehicles, Atmos. Environ., 131, 185-195, 2016.

Nakayama, T. Suzuki, H., Kagamitani, S., and Ikeda, Y.: Characterization of a three wavelength Photoacoustic Soot Spectrometer (PASS-3) and a Photoacoustic Extinctiometer (PAX), J. Meteorol. Soc. Japan, 93, 285-308, doi:10.2151/jmsj.2015-016, 2015.
Nepal Oil Corporation Limited: Import and Sales, available at: http://www.nepaloil.com.np/import-and-sales-22.html, last access: 8 January 2015.

Ng, N. L., Kroll, J. H., Chan, A. W. H., Chhabra, P. S., Flagan, R. C., and Seinfeld, J. H.: Secondary organic aerosol formation from $m$-xylene, toluene, and benzene, Atmos. Chem. Phys., 7, 3909-3922, doi:10.5194/acp-7-3909-2007, 2007.

Ntziachristos, L., Mamakos, A., Samaras, Z., Xanthopoulos, A., and Iakovou, E.: Emission control options for power two wheelers in Europe, Atmos. Environ., 40, 4547-4561, doi:10.1016/j.atmosenv.2006.04.003, 2006.

Ntziachristos, L., Geivanidis, S., Samaras, Z., Xanthopoulos, A., Steven, H., and Bugsel, B.: Study on possible new measures concerning motorcycle emissions, Revised Version, Report No. 08.RE.0019.V4, European Commission, Brussels, available at: http://righttoride.eu/regulationdocuments/report_ measures_motorcycle_emissions_en.pdf (last access: 2 September 2016), 2009.

Oanh, N. T. K., Phuong, M. T. T., and Permadi, D. A.: Analysis of motorcycle fleet in Hanoi for estimation of air pollution emission and climate mitigation co-benefit of technology implementation, Atmos. Environ., 59, 438-448, doi:10.1016/j.atmosenv.2012.04.057, 2012.

Organic Matter in Clays: Detailed Overview, available at: https://digitalfire.com/4sight/education/organic_matter_in_ clays_detailed_overview_325.html, last access: 11 January 2015.

Ortiz-Montalvo, D. L., Lim, Y. B., Perri, M. J., Seitzinger, S. P., and Turpin, B. J.: Volatility and yield of glycolaldehyde SOA formed through aqueous photochemistry and droplet evaporation, Aerosol Sci. Tech., 46, 1002-1014, doi:10.1080/02786826.2012.686676, 2012.

Ortega, J., Turnipseed, A., Guenther, A. B., Karl, T. G., Day, D. A., Gochis, D., Huffman, J. A., Prenni, A. J., Levin, E. J. T., Kreidenweis, S. M., DeMott, P. J., Tobo, Y., Patton, E. G., Hodzic, A., Cui, Y. Y., Harley, P. C., Hornbrook, R. S., Apel, E. C., Monson, R. K., Eller, A. S. D., Greenberg, J. P., Barth, M. C., CampuzanoJost, P., Palm, B. B., Jimenez, J. L., Aiken, A. C., Dubey, M. K., Geron, C., Offenberg, J., Ryan, M. G., Fornwalt, P. J., Pryor, S. C., Keutsch, F. N., DiGangi, J. P., Chan, A. W. H., Goldstein, A. H., Wolfe, G. M., Kim, S., Kaser, L., Schnitzhofer, R., Hansel, A., Cantrell, C. A., Mauldin, R. L., and Smith, J. N.: Overview of the Manitou Experimental Forest Observatory: site description and selected science results from 2008 to 2013, Atmos. Chem. Phys., 14, 6345-6367, doi:10.5194/acp-14-6345-2014, 2014.

Owen, E. and Jayasuriya, M. C. N.: Use of crop residues as animal feed in developing countries, Res. Dev. Agric., 6, 129-138, 1989.

Pang, Y., Fuentes, M., and Rieger, P.: Trends in the emissions of volatile organic compounds (VOCs) from lightduty gasoline vehicles tested on chassis dynamometers in Southern California, Atmos. Environ., 83, 127-135, doi:10.1016/j.atmosenv.2013.11.002, 2014.

Park, M., Randel, W. J., Emmons, L. K., Bernath, P. F., Walker, K. A., and Boone, C. D.: Chemical isolation in the Asian monsoon anticyclone observed in Atmospheric Chemistry Experiment (ACE-FTS) data, Atmos. Chem. Phys., 8, 757-764, doi:10.5194/acp-8-757-2008, 2008.

Pelkmans, L. and Debal, P.: Comparison of on-road emissions with emissions measured on chassis dynamometer test cycles, Trans- 
port Res. D-Tr. E., 11, 233-241,doi:10.1016/j.trd.2006.04.001, 2006.

Perry, R. and Gee, I. L.: Vehicle emissions in relation to fuel composition, Sci. Total Environ., 169, 149-156, doi:10.1016/00489697(95)04643-F, 1995.

Platt, S. M., El Haddad, I., Zardini, A. A., Clairotte, M., Astorga, C., Wolf, R., Slowik, J. G., Temime-Roussel, B., Marchand, N., Ježek, I., Drinovec, L., Mocnik, G., Möhler, O., Richter, R., Barmet, P., Bianchi, F., Baltensperger, U., and Prévôt, A. S. H.: Secondary organic aerosol formation from gasoline vehicle emissions in a new mobile environmental reaction chamber, Atmos. Chem. Phys., 13, 9141-9158, doi:10.5194/acp-13-91412013, 2013.

Platt, S. M., Haddad, I. E., Pieber, R.-J., Zardini, A. A., Clairotte, M., Suarez-Bertoa, R., Barmet, P., Pfaffenberger, L., Wolf, R., Slowik, J. G., Fuller, S. J., Kalberer, M., Chirico, R., Dommen, J., Astorga, C., Zimmermann, R., Marchand, N., Hellebust, S., Temime-Roussel, B., Baltensperger, U., and Prévôt, A. S. H.: Two-stroke scooters are a dominant source of air pollution in many cities, Nat. Commun., 5, 3749, doi:10.1038/ncomms4749, 2014.

Pokhrel, D. and Viraraghavan, T.: Municipal solid waste management in Nepal: practices and challenges, Waste Manage., 25, 555-562, doi:10.1016/j.wasman.2005.01.020, 2005.

Popp, P. J., Bishop, G. A., and Stedman, D. H.: Development of a high-speed ultraviolet spectrometer for remote sensing of mobil source nitric oxide emissions, J. Air Waste Manage., 49, 14631468, doi:10.1080/10473289.1999.10463978, 1999.

Praveen, P. S., Ahmed, T., Kar, A., Rehman, I. H., and Ramanathan, V.: Link between local scale BC emissions in the Indo-Gangetic Plains and large scale atmospheric solar absorption, Atmos. Chem. Phys., 12, 1173-1187, doi:10.5194/acp-12-1173-2012, 2012.

Presto, A. A., Miracolo, M. A., Donahue, N. M., and Robinson, A. L.: Secondary organic aerosol formation from high $\mathrm{NO}_{x}$ photooxidation of low volatility precursors: n-Alkanes, Environ. Sci. Technol., 44, 2029-2034, doi:10.1021/es903712r, 2010.

Putero, D., Cristofanelli, P., Marinoni, A., Adhikary, B., Duchi, R., Shrestha, S. D., Verza, G. P., Landi, T. C., Calzolari, F., Busetto, M., Agrillo, G., Biancofiore, F., Di Carlo, P., Panday, A. K., Rupakheti, M., and Bonasoni, P.: Seasonal variation of ozone and black carbon observed at Paknajol, an urban site in the Kathmandu Valley, Nepal, Atmos. Chem. Phys., 15, 13957-13971, doi:10.5194/acp-15-13957-2015, 2015.

Ramanathan, V. and Carmichael, G.: Global and regional climate changes due to black carbon, Nat. Geosci., 1, 221-227, doi:10.1038/ngeo156, 2008.

Randel, W. J., Park, M., Emmons, L., Kinnison, D., Bernath, P., Walker, K. A., Boone, C., and Pumphrey, H.: Asian monsoon transport of pollution to the stratosphere, Science, 328, 611-613, doi:10.1126/science.1182274, 2010.

Reid, J. S., Eck, T. F., Christopher, S. A., Koppmann, R., Dubovik, O., Eleuterio, D. P., Holben, B. N., Reid, E. A., and Zhang, J.: A review of biomass burning emissions part III: intensive optical properties of biomass burning particles, Atmos. Chem. Phys., 5, 827-849, doi:10.5194/acp-5-827-2005, 2005.

Richards, G. N.: Glycolaldehyde from pyrolysis of cellulose, J. Anal. Appl. Pyrol., 10, 251-255, doi:10.1016/01652370(87)80006-2, 1987.
Roden, C. A., Bond, T. C., Conway, S., Pinel, A. B. O., MacCarty, N., and Still, D.: Laboratory and field investigations of particulate and carbon monoxide emissions from traditional and improved cookstoves, Atmos. Environ., 43, 1170-1181, doi:10.1016/j.atmosenv.2008.05.041, 2008.

Ryerson, T. B., Andrews, A. E., Angevine, W. M., Bates, T. S., Brock, C. A., Cairns, B., Cohen, R. C., Cooper, O. R., de Gouw, J. A., Fehsenfeld, F. S., Ferrare, R. A., Fischer, M. L., Flagan, R. C., Goldstein, A. H., Hair, J. W., Hardesty, R. M., Hostetler, C. A., Jimenez, J. L., Langford, A. O., McCauley, E., McKeen, S. A., Molina, L. T., Nenes, A., Oltmans, S. J., Parrish, D. D., Pederson, J. R., Pierce, R. B., Prather, K., Quinn, P. K., Seinfeld, J. H., Senff, C. J., Sorooshian, A., Stutz, J., Surratt, J. D., Trainer, M., Volkamer, R., Williams, E. J., and Wofsy, S. C.: The 2010 California Research at the Nexus of Air Quality and Climate Change (CalNex) field study, J. Geophys. Res.-Atmos., 118, 5830-5866, doi:10.1002/jgrd.50331, 2013.

Saleh, R., Robinson, E. S., Tkacik, D. S., Ahern, A. T., Liu, S., Aiken, A. C., Sullivan, R. C., Presto, A. A., Dubey, M. K., Yokelson, R. J., Donahue, N. M., and Robinson, A. L.: Brownness of organics in aerosols from biomass burning linked to their black carbon content, Nat. Geosci., 7, 647-650, doi:10.1038/NGEO2220, 2014.

Sand, M., Berntsen, T. K., Kay, J. E., Lamarque, J. F., Seland, Ø., and Kirkevåg, A.: The Arctic response to remote and local forcing of black carbon, Atmos. Chem. Phys., 13, 211-224, doi:10.5194/acp-13-211-2013, 2013.

Sarkar, C., Sinha, V., Kumar, V., Rupakheti, M., Panday, A., Mahata, K. S., Rupakheti, D., Kathayat, B., and Lawrence, M. G.: Overview of VOC emissions and chemistry from PTR-TOFMS measurements during the SusKat-ABC campaign: high acetaldehyde, isoprene and isocyanic acid in wintertime air of the Kathmandu Valley, Atmos. Chem. Phys., 16, 3979-4003, doi:10.5194/acp-16-3979-2016, 2016.

Shah, T., Molden, D., Sakthivadivel, R., and Seckler, D.: The Global Groundwater Situation: Overview and Opportunities and Challenges, International Water Management Institute, Colombo, Sri Lanka, 2000.

Shrestha, S. R., Oanh, N. T. K., Zu, Q., Rupakheti, M., and Lawrence, M. G.: Analysis of the vehicle fleet in the Kathmandu Valley for estimation of environment and climate cobenefits of technology intrusions, Atmos. Environ., 81, 579-590, doi:10.1016/j.atmosenv.2013.09.050, 2013.

Simpson, I. J., Rowland, F. S., Meinardi, S., and Blake, D. R.: Influence of biomass burning during recent fluctuations in the slow growth of global tropospheric methane, Geophys. Res. Lett., 33, L22808, doi:10.1029/2006GL027330, 2006.

Simpson, I. J., Akagi, S. K., Barletta, B., Blake, N. J., Choi, Y., Diskin, G. S., Fried, A., Fuelberg, H. E., Meinardi, S., Rowland, F. S., Vay, S. A., Weinheimer, A. J., Wennberg, P. O., Wiebring, P., Wisthaler, A., Yang, M., Yokelson, R. J., and Blake, D. R.: Boreal forest fire emissions in fresh Canadian smoke plumes: $\mathrm{C}_{1}-\mathrm{C}_{10}$ volatile organic compounds (VOCs), $\mathrm{CO}_{2}, \mathrm{CO}, \mathrm{NO}_{2}$, $\mathrm{NO}, \mathrm{HCN}$ and $\mathrm{CH}_{3} \mathrm{CN}$, Atmos. Chem. Phys., 11, 6445-6463, doi:10.5194/acp-11-6445-2011, 2011.

Sinha, V., Kumar, V., and Sarkar, C.: Chemical composition of premonsoon air in the Indo-Gangetic Plain measured using a new air quality facility and PTR-MS: high surface ozone and strong 
influence of biomass burning, Atmos. Chem. Phys., 14, 59215941, doi:10.5194/acp-14-5921-2014, 2014.

Smith, K., Uma, R., Kishore, V. V. N., Lata, K., Joshi, V., Zhang, J., Rasmussen, R. A., and Khalil, M. A. K.: Greenhouse gases from small-scale combustion devices in developing countries: Household stoves in India, Rep. EPA-600/R-00-052, U.S. Environ. Prot. Agency, Research Triangle Park, NC, USA, 2000.

Smith, K. R., Frumkin, H., Balakrishnan, K., Butler, C. D., Chafe, Z. A., Fairlie, I., Kinney, P., Kjellstrom, T., Mauzerall, D. L., McKone, T. E., McMichael, A. J., and Schneider, M.: Energy and human health, Annu. Rev. Public Health, 34, 1-25, doi:10.1146/annurev-publhealth-031912-114404, 2013.

Stockwell, C. E., Yokelson, R. J., Kreidenweis, S. M., Robinson, A. L., DeMott, P. J., Sullivan, R. C., Reardon, J., Ryan, K. C., Griffith, D. W. T., and Stevens, L.: Trace gas emissions from combustion of peat, crop residue, domestic biofuels, grasses, and other fuels: configuration and Fourier transform infrared (FTIR) component of the fourth Fire Lab at Missoula Experiment (FLAME4), Atmos. Chem. Phys., 14, 9727-9754, doi:10.5194/acp-149727-2014, 2014.

Stockwell, C. E., Veres, P. R., Williams, J., and Yokelson, R. J.: Characterization of biomass burning emissions from cooking fires, peat, crop residue, and other fuels with high-resolution proton-transfer-reaction time-of-flight mass spectrometry, Atmos. Chem. Phys., 15, 845-865, doi:10.5194/acp-15-845-2015, 2015.

Streets, D. G., Yarber, K. F., Woo, J. H., and Carmichael, G. R.: Biomass burning in Asia: annual and seasonal estimates and atmospheric emissions, Global Biogeochem. Cy., 17, 1099, doi:10.1029/2003GB002040, 2003.

Subramanian, R., Roden, C. A., Boparai, P., and Bond, T. C.: Yellow beads and missing particles: Trouble ahead for filter-based absorption measurements, Aerosol Sci. Technol., 41, 630-637, doi:10.1080/02786820701344589, 2007.

Tsai, W. Y., Chan, L. Y., Blake, D. R., and Chu, K. W.: Vehicular fuel composition and atmospheric emissions in South China: Hong Kong, Macau, Guangzhou, and Zhuhai, Atmos. Chem. Phys., 6, 3281-3288, doi:10.5194/acp-6-3281-2006, 2006.

USEPA: Motor vehicle-related air toxics study, United States Environmental Protection Agency, available at: http://www3.epa.gov/ otaq/regs/toxics/airtox1a.pdf (last access: 11 November 2015), 1993.

USEPA: Compilation of air pollutant emission factors (AP-42), Section 11.3: Brick and structural clay product manufacturing, Midwest Research Institute for the Office of Air Quality Planning and Standards, U.S. Environmental Protection Agency, Research Triangle Park, North Carolina, USA, 1997.

USEPA: An inventory of sources and environmental releases of dioxin-like compounds in the United States for the years 1987, 1995, and 2000, EPA/600/P-03/002F, National Center for Environmental Assessment, Office of Research and Development, Washington, DC, USA, 677 pp., 2006.

USEPA: Environmental and sustainable technology evaluation: Biomass co-firing in industrial boilers - Minnesota Power's Rapids Energy Center, United States Environmental Protection Agency, EPA/600/R-08/057, Washington, DC, USA, 2007.

USEPA: Plastics, United States Environmental Protection Agency, available at: http://www3.epa.gov/climatechange/wycd/ waste/downloads/plastics-chapter10-28-10.pdf (last access: 11 November 2015), 2010.

USEPA: The Compilation of Air Pollutant Emission Factors, Volume I: Stationary Point and Area Sources, United States Environmental Protection Agency, available at: http://www3.epa.gov/ ttnchie1/ap42/ (last access: 2 September 2016), 2015.

Vaughan, T. L., Strader, C., Davis, S., and Daling, J. R.: Formaldehyde and cancers of the pharynx, sinus and nasal cavity: II. Residential exposures, Int. J. Cancer, 38, 685-688, doi:10.1002/ijc.2910380511, 1986.

Venkataraman, C., Habib, G., Eiguren-Fernandez, A., Miguel A. H., and Friedlander S. K.: Residential Biofuels in South Asia: Carbonaceous Aerosol Emissions and Climate Impacts, Science, 307, 1454-1456, doi:10.1126/science.1104359, 2005.

Vestreng, V., Ntziachristos, L., Semb, A., Reis, S., Isaksen, I. S. A., and Tarrasón, L.: Evolution of $\mathrm{NO}_{x}$ emissions in Europe with focus on road transport control measures, Atmos. Chem. Phys., 9, 1503-1520, doi:10.5194/acp-9-1503-2009, 2009.

Volkamer, R., Sheehy, P., Molina, L. T., and Molina, M. J.: Oxidative capacity of the Mexico City atmosphere - Part 1: A radical source perspective, Atmos. Chem. Phys., 10, 6969-6991, doi:10.5194/acp-10-6969-2010, 2010.

Ward, D. E. and Radke, L. F.: Emissions measurements from vegetation fires: A Comparative evaluation of methods and results, in: Fire in the Environment: The Ecological, Atmospheric and Climatic Importance of Vegetation Fires, edited by: Crutzen, P. J. and Goldammer, J. G., John Wiley, New York, USA, 53-76, 1993.

Wattel-Koekkoek, E. J. W., van Genuchten, P. P. L., Buurman, P., and van Lagen, B.: Amount and composition of clay-associated soil organic matter in a range of kaolinitic and smectitic soils, 99, 27-49, doi:10.1016/S0016-7061(00)00062-8, 2001.

WECS: Energy consumption situation in Nepal (Year 2011/12), Water and Energy Commission Secretariat, Government of Nepal, Kathmandu, 2014.

Weyant, C., Athalye, V., Ragavan, S., Rajarathnam, U., Lalchandani, D., Maithel, S., Baum, E., and Bond, T. C.: Emissions from South Asian Brick Production, Environ. Sci. Technol., 48, 64776483, doi:10.1021/es500186g, 2014.

Wiedinmyer, C., Yokelson, R. J., and Gullett, B. K.: Global emissions of trace gases, particulate matter, and hazardous air pollutants from open burning of domestic waste, Environ. Sci. Technol., 48, 9523-9530, doi:10.1021/es502250z, 2014.

World Bank: Diesel Power Generation: Inventories and black carbon emissions in Kathmandu Valley, Nepal, International Bank for Reconstruction and Development, Washington DC, USA, 2014.

Xiao, Q., Saikawa, E., Yokelson, R. J., Chen, P., Li, C., and Kang, S.: Indoor air pollution from burning yak dung as a household fuel in Tibet, Atmos. Environ., 102, 406-412, doi:10.1016/j.atmosenv.2014.11.060, 2015.

Yanowitz, J., Graboski, M. S., Ryan, L. B. A., Alleman, T., and McCormick, R.: Chassis dynamometer study of emissions from 21 in-use heavy-duty diesel vehicles, Environ. Sci. Technol., 33, 209-216, doi:10.1021/es980458p, 1999.

Yevich, R. and Logan, J. A.: An assessment of biofuel use and burning of agricultural waste in the developing world, Global Biogeochem. Cy., 17, 1095, doi:10.1029/2002GB001952, 2003. 
Yokelson, R. J., Griffith, D. W. T., and Ward, D. E.: Open path Fourier transform infrared studies of large-scale laboratory biomass fires, J. Geophys. Res., 101, 21067-21080, doi:10.1029/96JD01800, 1996.

Yokelson, R. J., Ward, D. E., Susott, R. A., Reardon, J., and Griffith, D. W. T.: Emissions from smoldering combustion of biomass measured by open-path Fourier transform infrared spectroscopy, J. Geophys. Res., 102, 18865-18877, doi:10.1029/97JD00852, 1997.

Yokelson, R. J., Goode, J. G., Ward, D. E., Susott, R. A., Babbitt, R. E., Wade, D. D., Bertschi, I., Griffith, D. W. T., and Hao, W. M.: Emissions of formaldehyde, acetic acid, methanol, and other trace gases from biomass fires in North Carolina measured by airborne Fourier transform infrared spectroscopy, J. Geophys. Res., 104, 30109-30125, doi:10.1029/1999jd900817, 1999.

Yokelson, R. J., Christian, T. J., Bertschi, I. T., and Hao, W. M.: Evaluation of adsorption effects on measurements of ammonia, acetic acid, and methanol, J. Geophys. Res., 108, 4649, doi:10.1029/2003JD003549, 2003.

Yokelson, R. J., Karl, T., Artaxo, P., Blake, D. R., Christian, T. J., Griffith, D. W. T., Guenther, A., and Hao, W. M.: The Tropical Forest and Fire Emissions Experiment: overview and airborne fire emission factor measurements, Atmos. Chem. Phys., 7, 5175-5196, doi:10.5194/acp-7-5175-2007, 2007

Yokelson, R. J., Christian, T. J., Karl, T. G., and Guenther, A.: The tropical forest and fire emissions experiment: laboratory fire measurements and synthesis of campaign data, Atmos. Chem. Phys., 8, 3509-3527, doi:10.5194/acp-8-3509-2008, 2008.

Yokelson, R. J., Crounse, J. D., DeCarlo, P. F., Karl, T., Urbanski, S., Atlas, E., Campos, T., Shinozuka, Y., Kapustin, V., Clarke, A. D., Weinheimer, A., Knapp, D. J., Montzka, D. D., Holloway, J., Weibring, P., Flocke, F., Zheng, W., Toohey, D., Wennberg, P. O., Wiedinmyer, C., Mauldin, L., Fried, A., Richter, D., Walega, J., Jimenez, J. L., Adachi, K., Buseck, P. R., Hall, S. R., and Shetter, R.: Emissions from biomass burning in the Yucatan, Atmos. Chem. Phys., 9, 5785-5812, doi:10.5194/acp-9-5785-2009, 2009.
Yokelson, R. J., Burling, I. R., Urbanski, S. P., Atlas, E. L., Adachi, K., Buseck, P. R., Wiedinmyer, C., Akagi, S. K., Toohey, D. W., and Wold, C. E.: Trace gas and particle emissions from open biomass burning in Mexico, Atmos. Chem. Phys., 11, 67876808, doi:10.5194/acp-11-6787-2011, 2011.

Yokelson, R. J., Burling, I. R., Gilman, J. B., Warneke, C., Stockwell, C. E., de Gouw, J., Akagi, S. K., Urbanski, S. P., Veres, P., Roberts, J. M., Kuster, W. C., Reardon, J., Griffith, D. W. T. Johnson, T. J., Hosseini, S., Miller, J. W., Cocker III, D. R., Jung, H., and Weise, D. R.: Coupling field and laboratory measurements to estimate the emission factors of identified and unidentified trace gases for prescribed fires, Atmos. Chem. Phys., 13, 89-116, doi:10.5194/acp-13-89-2013, 2013.

Zachariadis, T., Ntziachristos, L., and Samaras, Z.: The effect of age and technological change on motor vehicle emissions, Transport Res. D-Tr. E., 6, 221-227, doi:10.1016/S1361-9209(00)00025-0, 2001.

Zavala, M., Herndon, S. C., Slott, R. S., Dunlea, E. J., Marr, L. C., Shorter, J. H., Zahniser, M., Knighton, W. B., Rogers, T. M., Kolb, C. E., Molina, L. T., and Molina, M. J.: Characterization of on-road vehicle emissions in the Mexico City Metropolitan Area using a mobile laboratory in chase and fleet average measurement modes during the MCMA-2003 field campaign, Atmos. Chem. Phys., 6, 5129-5142, doi:10.5194/acp-6-5129-2006, 2006.

Zhang, Y., Stedman, D. H., Guenther, P. L., Beaton, S. P., and Peterson, J. E.: On-road hydrocarbon remote sensing in the Denver area, Environ. Sci. Technol., 27, 1885-1891, doi:10.1021/es00046a018, 1993.

Zhang, Y., Stedman, D. H., Bishop, G. A., Guenther, P. L., and Beaton, S. P.: Worldwide on-road vehicle exhaust emissions study by remote sensing, Environ. Sci. Technol., 29, 2286-2294, doi:10.1021/es00009a020, 1995. 